\title{
Fluid inclusion study of gypsum precipitated in acid saline waters: Salar Ignorado, northern Chile
}

Francis John Karmanocky III

West Virginia University

Follow this and additional works at: https://researchrepository.wvu.edu/etd

\section{Recommended Citation}

Karmanocky, Francis John III, "Fluid inclusion study of gypsum precipitated in acid saline waters: Salar Ignorado, northern Chile" (2014). Graduate Theses, Dissertations, and Problem Reports. 5015.

https://researchrepository.wvu.edu/etd/5015

This Thesis is protected by copyright and/or related rights. It has been brought to you by the The Research Repository @ WVU with permission from the rights-holder(s). You are free to use this Thesis in any way that is permitted by the copyright and related rights legislation that applies to your use. For other uses you must obtain permission from the rights-holder(s) directly, unless additional rights are indicated by a Creative Commons license in the record and/ or on the work itself. This Thesis has been accepted for inclusion in WVU Graduate Theses, Dissertations, and Problem Reports collection by an authorized administrator of The Research Repository @ WVU. For more information, please contact researchrepository@mail.wvu.edu. 


\title{
Fluid inclusion study of gypsum precipitated in acid saline waters: Salar Ignorado, northern Chile
}

\author{
Francis John Karmanocky III
}

\author{
Thesis submitted \\ to the Eberly College of Arts and Sciences \\ at West Virginia University \\ in partial fulfillment of the requirements \\ for the degree of \\ Master of Science in \\ Geology
Kathleen C. Benison, Ph.D., Chair
Helen M. Lang, Ph.D.
Dorothy J. Vesper, Ph.D. \\ Department of Geology and Geography \\ Morgantown, West Virginia \\ 2014
}
Keywords: Chile; Salar; Acid; Gypsum; Fluid Inclusion; Hydrogen Sulfide; $\mathrm{H}_{2} \mathrm{~S}$; Laser Raman Spectroscopy; Organic Compounds

Copyright (C) 2014, Francis John Karmanocky III 
Karmanocky, F. J. III, 2014

\begin{abstract}
Fluid inclusion study of gypsum precipitated in acid saline waters: Salar Ignorado, northern Chile
\end{abstract}

Francis John Karmanocky III

Salar Ignorado is situated at high elevation in the Andes Mountains of northern Chile in an extremely arid, small, intervolcanic basin and contains pools of acid ( $\mathrm{pH} 3.3-$ 4.1) saline (5 - 30 ppth) water that are precipitating gypsum crystals. Gypsum crystals trap acid saline water from the pools as fluid inclusions. Little research has been conducted on fluid inclusions in gypsum. At Salar Ignorado two types of bottom-growth gypsum form from the surface pools: large bladed and tiny needle-like crystals. Salar Ignorado gypsum contains primary fluid inclusions of three distinct morphologies, oriented parallel to crystal face. Petrography and microthermometry were performed on 27 gypsum crystals from Salar Ignorado. Most primary fluid inclusions are all liquid, however some primary inclusions are composed of liquid and a gas phase. One large gypsum crystal, hosting primary fluid inclusions along 28 successive growth bands, was the focus for fluid inclusion studies. Microthermometric results in geochemical trends. This crystal shows a change in parent fluids, during growth, from low salinity to high salinity to low salinity. At the bottom of the crystal, the lowest six fluid inclusion assemblages have salinities of 1.7 to 5.1 eq. wt. $\% \mathrm{NaCl}$. The next nine fluid inclusion assemblages have significantly higher salinity ( 18.6 and 25.5 eq. wt. $\% \mathrm{NaCl}$ ) inclusions. The twelve fluid inclusion assemblages near the top of the crystal have low salinity (1.6 to 7.9 eq. wt. $\% \mathrm{NaCl}$ ) like those at the bottom of the crystal. The high salinity fluid inclusions in the middle of this gypsum crystal are interpreted as the migration of hydrothermal fluids to the surface, which are intimately linked to the local active magmatism. Secondary evidence of hydrothermal pulses are high molecular weight hydrocarbons and hydrogen sulfide odors upon crushing.

A variety of microorganisms are trapped both as solid inclusions and as potentially viable halophilic and acidophilic prokaryotes and eukaryotes within fluid inclusions in this Mars-analog gypsum. Pennate diatoms, green algae, and prokaryotes have been documented in gypsum precipitated from acid $(\mathrm{pH} 1.8-4.6)$ saline $(5 \%-28 \%$ total dissolved solids) waters at Salar Ignorado and its larger neighbor, Salar Gorbea. Evaluation of Salar Ignorado gypsum indicates that primary fluid inclusions record hydrochemistry and microbiology of various intervals of waters. This study has implications for detailed interpretations of past environments from ancient gypsum in the rock record, as well as clues for the search for life on Mars.

This thesis has shown for the first time that primary fluid inclusions in gypsum can serve as proxies for various environmental conditions. Detailed study of Salar Ignorado gypsum has identified trends in surface water salinity, degassing of hydrogen sulfide and hydrocarbons, and fossilization of microorganisms. 
Karmanocky, F. J. III, 2014

\section{ACKNOWLEDGEMENTS}

I would like to thank the many individuals that have helped to contribute to this research, and each has left a lasting impression. This research would not have begun if it was not for T. James Reynolds sparking my interest in fluid inclusion related research. Robert C. Burruss and I-Ming Chou at the USGS in Reston, VA gave me plenty of fluid inclusion and laser Raman support. Bob Burruss also provided sound advice and pushed me to hone my research question: "You are faced with a classic problem of fluid inclusion research. That is, defining the problem you want to address with analytical results. I am certain that you will get results of some kind. Whether they really address your research problem is another matter. What are you trying to learn?" Tim K. Lowenstein helped me evaluate fluid inclusions in gypsum as actually being primary and confirming the presence of microorganisms in the samples. Though I only spoke with Robert H. Goldstein on a few brief occasions he provided me with valuable insights into fluid inclusions and fluid inclusion related topics.

Of course, this research would not have been possible without the many hours of tutelage, encouragement, and moral support of Dr. Kathleen C. Benison, nor would have it been possible without the samples that were collected by Dr. Benison and her colleagues: Maria Mercedes Gonzalez, Diane Goulder, and Jorge Vorpahl. Kathy did not only serve as a graduate advisor, but as a mentor. I would also like to extend a very deserved thanks to my committee of Helen M. Lang and Dorothy J. Vesper for scientific insights and edits for thesis writing and testing the author. I know we are all busy, especially the faculty with other graduate students, department service, and their own research; yet they were still able to dedicate time to my research. 
I thank all the current and past graduate students at WVU including: John Brockman, Chris Kramer, Marcus Jesse, Ben Johnson, and my officemate Lindsey Bowman, who listened to me ramble on about fluid inclusions or to know when to drag me from my office for a trip to the Brew Pub. The Sedimentary Petrology and Fluid Inclusion classes contributed to petrographic observations and interpretations of fluid inclusions and their contents.

My sanity may have been in jeopardy if it were not for the support provided by Tara Spinos, Paxton (the miniature pinscher) for a calming distraction, and Baxter (the labradoodle) for endless hours of comic relief. My mom, Heidi Prohonic, always had an extensive list of chores to momentarily distract me in times of writer's block and the occasional transient lack of cognitive ability.

Also my friends outside of WVU including Bill Schellenbach and Chuck Romanchock who provided encouragement to keep going, keep writing, because even if I couldn't see the light at the end of the tunnel, they knew it was there and that it was in reach.

For all those that the author neglected to include, it was not a lack of appreciation, rather the, "occasional transient lack of cognitive ability" that occurs when composing a Thesis, and I thank them.

Lastly, but most importantly, I would never have made it to this point today if it weren't for my father, Daniel Prohonic. He pushed and pressed me to continue my schooling, he knew I had a passion for learning (even if it at times it was learning some things the hard way!). He saw the work I was doing post undergraduate, and he knew I could do better; he dreamed of seeing me do better than him, and that one day I could 
support him and my mom. Unfortunately he passed away prior to my return to school and he can never see this dream come to fruition. The passion and desire I have to work late into the night and to begin early in the morning, is for him. I can hear his words of wisdom every step of the way and for him this thesis is dedicated.

The financial burden of this project was eased by grants and funding from: West Virginia University, Geological Society of America, and the Milton Tidd and Doris E. Heald Promising Researcher Award; and facility support by the United States Geologic Survey in Reston, VA. 
Karmanocky, F. J. III, 2014

For Daniel J. Prohonic 


\section{TABLE OF CONTENTS}

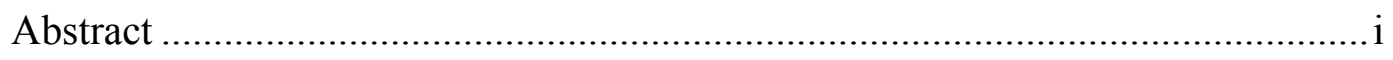

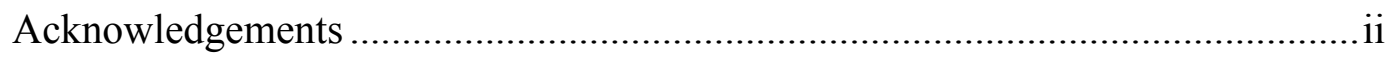

Table of Contents ......................................................................................... vi

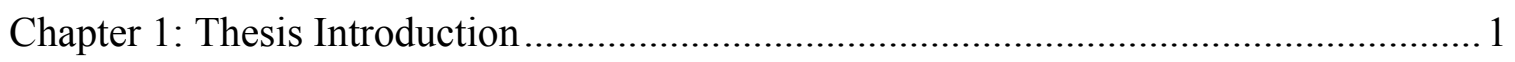

Chapter 2: Evaluation of fluid inclusions in modern gypsum precipitating from acid

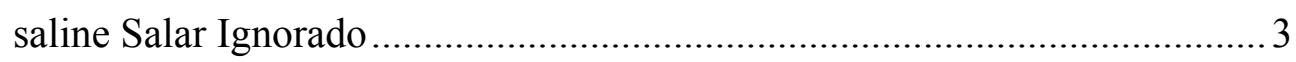

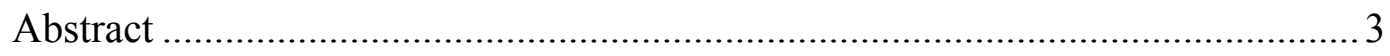

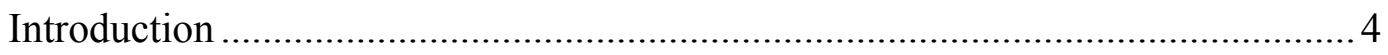

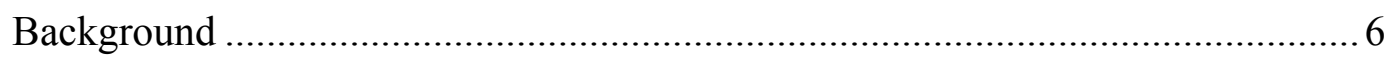

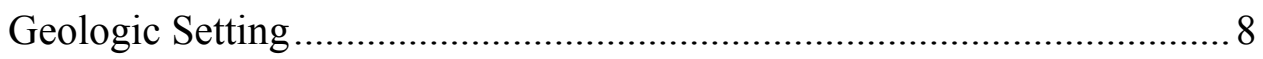

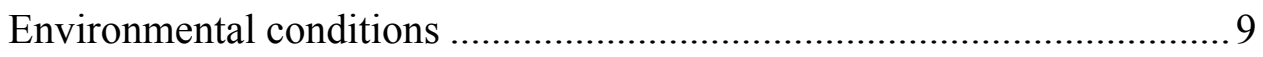

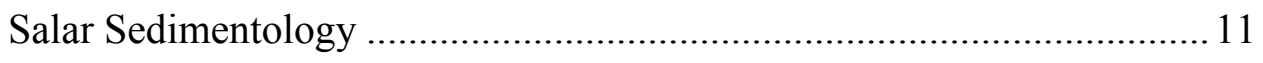

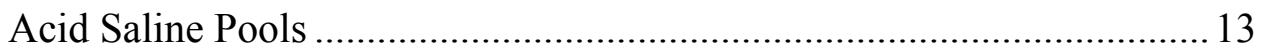

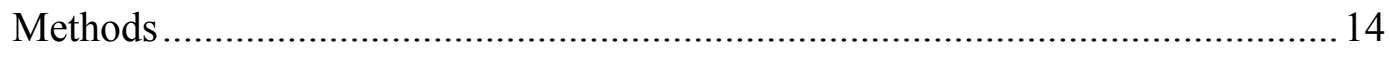

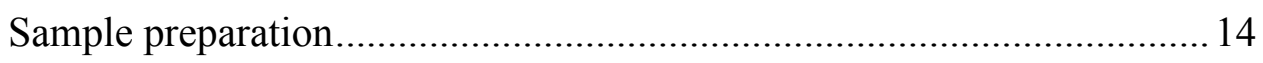

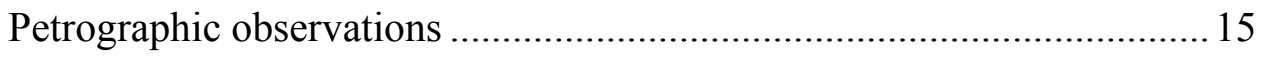

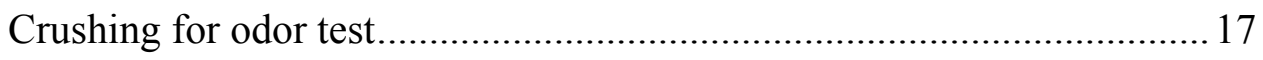

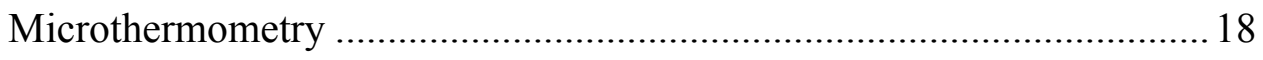

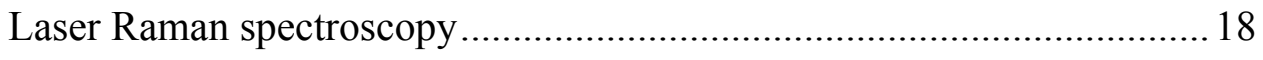


Results

Petrography of Salar Ignorado Gypsum.

Fluid inclusion petrography

Solid Inclusions in Gypsum 26

Laser Raman spectroscopy

Microthermometry of primary fluid inclusions

Discussion .35

Conditions that control the precipitation of gypsum .35

Microorganisms and organic matter trapped in fluid inclusions 36

Fluid inclusion petrography of gypsum: environmental implications ...... 37

Possible fluid evolution models .39

Model \#1: Hydrothermal source .39

Model \#2: Meteoric influence .40

Model \#3: Mixed fluid source 40

Model evaluation. 40

Other fluid evolution model considerations 43

Conclusions .45

Chapter 3: Could microorganisms be preserved in Mars gypsum? Insights from terrestrial examples .47

Abstract 47 


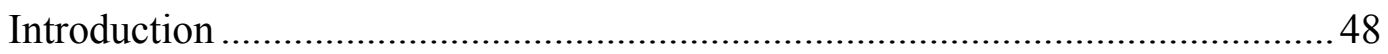

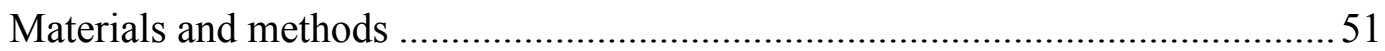

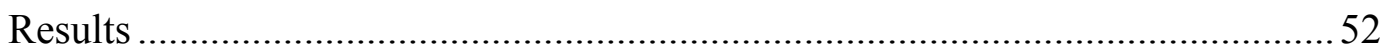

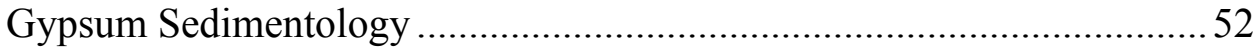

Fluid Inclusion Petrography ................................................................. 52

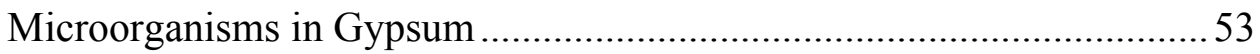

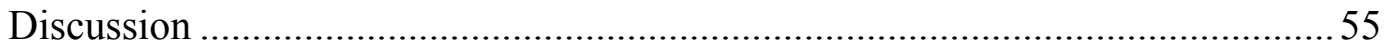

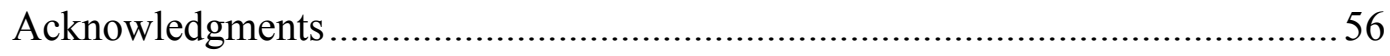

Chapter 4: Conclusions and Recommendations...........................................................57

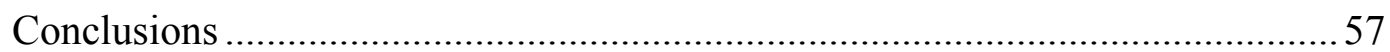

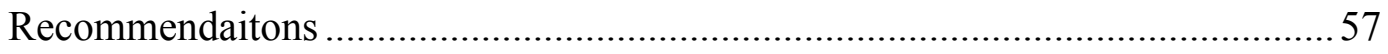

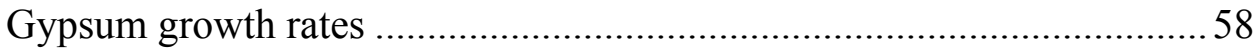

Step One: Sample collection ....................................................... 58

Step Two: Growing samples in the lab .........................................59

Step Three: Petrography of laboratory grown gypsum crystals ....59

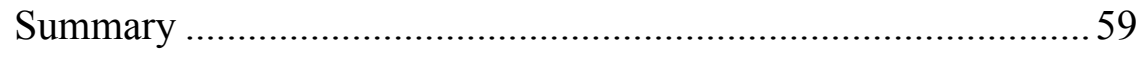

Mechanisms that control gypsum growth .................................................. 60

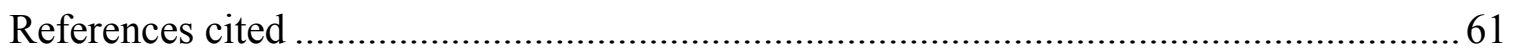




\section{APPENDICES}

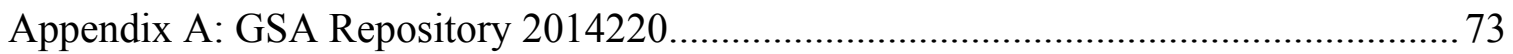

Could microorganisms be preserved in Mars gypsum? Insights from terrestrial examples

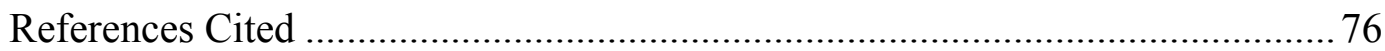

Appendix B: Salars Gorbea and Ignorado Chemistry Data ..............................................77

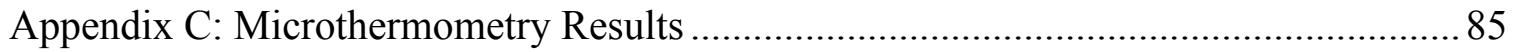

Appendix D: Photographs of low salinity freezing-melting run

Appendix E: Photographs of high salinity freezing-melting run

Appendix F: Barometric pressure calculations for a range of climactic possibilities at Salar Ignorado 102 


\section{Chapter 1: Thesis Introduction}

This thesis was written in partial fulfillment of the requirements for the degree of Master of Science in Geology from the Department of Geology and Geography of the Eberly School of Arts and Sciences. The formatting of this Thesis has been arranged in four chapters to allow the reader to follow particular topics of the research of the author more clearly. This Thesis has been organized in the following fashion: Chapter 1: Thesis Introduction, Chapter 2: Gypsum as recorders of hydrochemistry at Salar Ignorado, Chapter 3: Could microorganisms be preserved in Mars gypsum? Insights from terrestrial examples, and Chapter 4: Conclusions and recommendations for future work.

Chapter 2 is an evaluation of the petrographic and microthermometric aspects of gypsum found at Salar Ignorado. This chapter aims to evaluate the evolution of Salar Ignorado through time. Conventional studies of evaporite deposits look to determine whether the evaporites were deposited as a result of a marine, non-marine, or a combined influence, but in the Andes Mountains of Chile, Salar Ignorado is located quite far from marine influence. In the case of Salar Ignorado, the question is whether the evaporites formed as a result of hydrothermal or volcanogenic fluids, meteoric fluids, or a combination of the two sources. Evidence to address this hypothesis will be presented in the form of petrographic observations, microthermometry, and laser Raman spectroscopy.

Parts of Chapter 2 were presented at the Geological Society of America Annual Meeting in Denver, CO, October 2013, and the Pan American Current Research on Fluid Inclusions meeting in Pingree Park, CO, June 2014. Fluid inclusion data and interpretations from Chapter 2 will be prepared to be submitted as a manuscript to the 
journal Geofluids, whereas gypsum and fluid inclusion petrography will be submitted to the journal The Canadian Mineralogist.

Chapter 3 poses the question as to the prospect that viable life may still exist on Mars today. Gypsum samples that were collected from Salar Ignorado and Salar Gorbea contain fluid inclusions that trap microorganisms and organic compounds. This is a mode of fossilization that has not been considered by Mars researchers. The geologic and geochemical setting of Salars Ignorado and Gorbea serve as an excellent analog to Mars. It is possible and likely that the gypsum that has been found on Mars contains samples of a possibly living, yet isolated and likely dormant, microbiological community.

The work described in Chapter 3 was partially presented at the Geological Society of America Annual Meeting in Denver, CO, October 2013, and the Pan American Current Research on Fluid Inclusions meeting in Pingree Park, CO, June 2014. This work was published in the July 2014 issue of the journal Geology.

Conclusions and recommendations for future studies of the Thesis are located in Chapter 4. There are still questions to be answered even though many of the goals of this research project have been addressed. A few possible topics include looking at how fluid inclusion assemblages relate to growth rates of gypsum.

The collection of gypsum samples from Salar Ignorado and field data was conducted by Kathleen C. Benison, Maria Mercedes Gonzalez, Diane Goulder, and Jorge Vorpahl. Analysis of the gypsum samples from Salar Ignorado was conducted by the author. Analysis includes: petrography, microthermometry, and laser Raman spectroscopy described in this thesis. 
Karmanocky, F. J. III, 2014

\title{
Chapter 2: Evaluation of fluid inclusions in modern gypsum precipitating from acid saline Salar Ignorado
}

\begin{abstract}
Salar Ignorado is situated at high elevation in the Andes Mountains of northern Chile in an extremely arid, small, intervolcanic basin and contains pools of acid (pH $3.3-$ 4.1) saline (5 - 30 ppth) water that are precipitating gypsum crystals. Gypsum crystals trap acid saline water from the pools as fluid inclusions. Little research has been conducted on fluid inclusions in gypsum. At Salar Ignorado two types of bottom-growth gypsum form from the surface pools: large bladed and tiny needle-like crystals. Salar Ignorado gypsum contains primary fluid inclusions of three distinct morphologies, oriented parallel to crystal face. Petrography and microthermometry were performed on 27 gypsum crystals from Salar Ignorado. Most primary fluid inclusions are all liquid, however some primary inclusions are composed of liquid and a gas phase. One large gypsum crystal, hosting primary fluid inclusions along 28 successive growth bands, was the focus for fluid inclusion studies. Microthermometric results in geochemical trends. This crystal shows a change in parent fluids, during growth, from low salinity to high salinity to low salinity. At the bottom of the crystal, the lowest six fluid inclusion assemblages have salinities of 1.7 to 5.1 eq. wt. $\% \mathrm{NaCl}$. The next nine fluid inclusion assemblages have significantly higher salinity ( 18.6 and 25.5 eq. wt. $\% \mathrm{NaCl}$ ) inclusions. The twelve fluid inclusion assemblages near the top of the crystal have low salinity (1.6 to 7.9 eq. wt. $\% \mathrm{NaCl}$ ) like those at the bottom of the crystal. The high salinity fluid inclusions in the middle of this gypsum crystal are interpreted as the migration of hydrothermal fluids to the surface, which are intimately linked to the local active magmatism. Secondary evidence of hydrothermal pulses are high molecular weight hydrocarbons and hydrogen sulfide odors upon crushing.
\end{abstract}


Karmanocky, F. J. III, 2014

\section{INTRODUCTION}

In the Cordillera de los Andes of South America, salar brines, precipitate evaporite mineral assemblages. Most of the salars found in the Andes contain neutral to alkaline waters. Risacher et al. (2002) documented $\mathrm{pH}$ and salinity at 84 salars in northern Chile and Bolivia and found only two salars with acid saline waters, Salar Ignorado and Salar Gorbea (Figure 1). Where are the fluids that source these Salars originating? The region that hosts Salars Ignorado and Gorbea is the driest on the planet, and in this harsh environment there are limited modes of transport for fluids.

The possibilities for sources of acid saline sulfate waters at Salar Ignorado are: (1) meteoric precipitation infiltrating and percolating into a shallow aquifer, (2) multiple generations or cycles hydrothermal fluids migrating to the surface, or (3) a mixing of the these two systems are the most likely possibilities. One recorder of past environmental conditions is fluid inclusions in evaporite minerals that precipitate from salars. The most abundant evaporite mineral available at Salar Ignorado is gypsum $\left(\mathrm{CaSO}_{4} \cdot 2 \mathrm{H}_{2} \mathrm{O}\right)$, which contains abundant fluid inclusions.

The principal objective of this study is to evaluate the potential of primary fluid inclusions in the gypsum precipitated in Salar Ignorado to record water temperature, chemistry, $\mathrm{pH}$, microbiology, and any changes in those characteristics through time. Fluid inclusion assemblages within chemical sediments can record trends in the temperature and chemical composition of parent waters (i.e., Goldstein and Benison, 1999). Evidence of past life in saline environments includes prokaryotes and Dunaliella algae, such as those in fluid inclusions in halite from Saline Valley and Death Valley (Schubert et al., 2009; Schubert et al., 2010; Lowenstein et al., 2011) and prokaryotes, 
Karmanocky, F. J. III, 2014

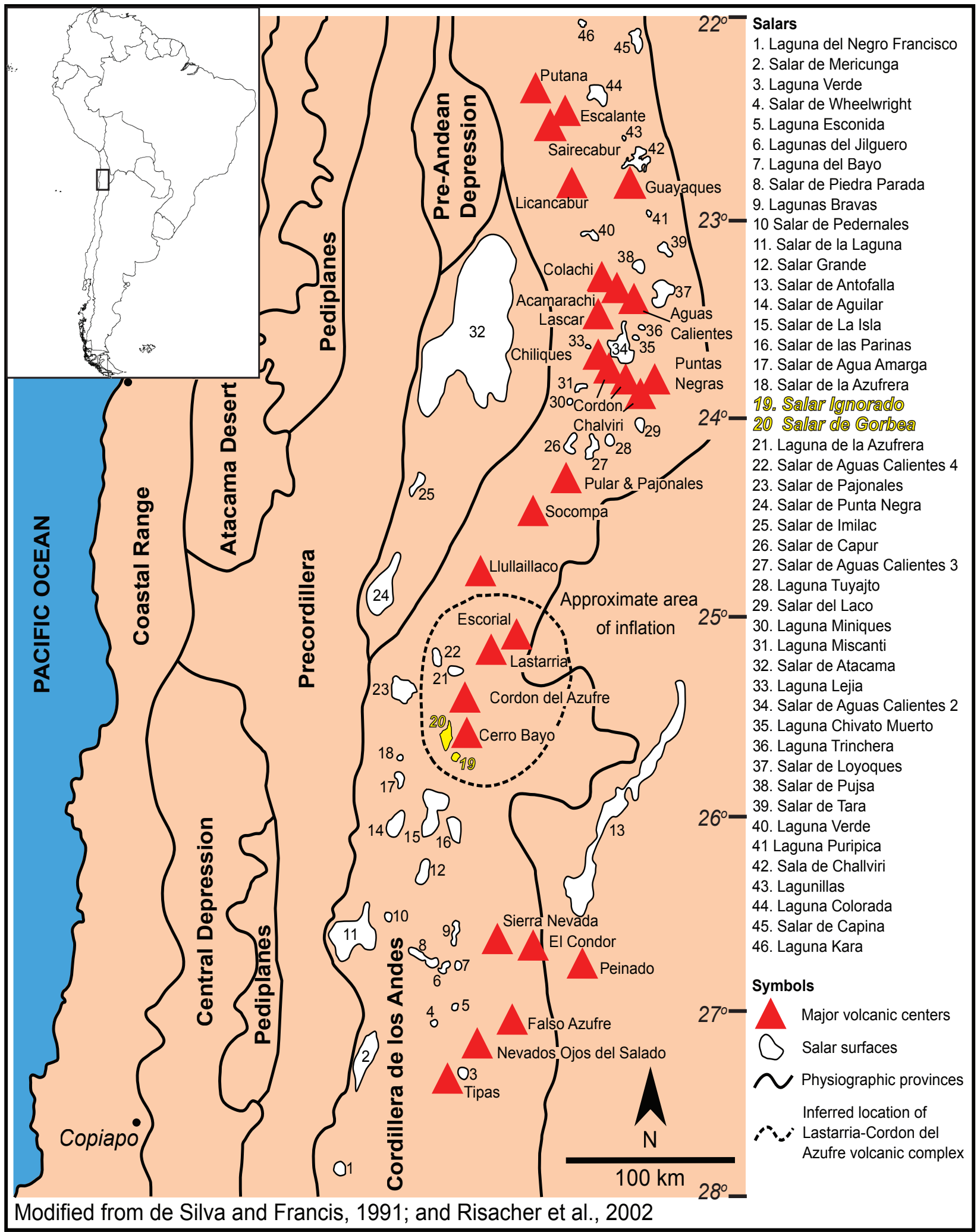

Figure 1. Physiographic provinces of the Central Volcanic Zone of Chile. The dashed area indicates the extent of surface expansion caused by the Lastarria-Cordon del Azufre volcanic complex with Salar Ignorado [19] and Salar Gorbea [20] are located in the southwestern quadrant of the expanded area. 
Dunaliella algae, and beta-carotene in fluid inclusions in acid-precipitated halite from Western Australia (Jagniecki and Benison, 2010; Conner and Benison, 2013). It is also important to document these inclusions petrographically to determine their origin and preservation so future workers who encounter gypsum will be able to properly evaluate them. Understanding the compositions of the fluid inclusions in the acid-precipitated gypsum will aid in establishing criteria for identifying acid environments through geologic time. Understanding the recent geochemical and microbiological history of Salar Ignorado will have implications in reconstructing paleoenvironments terrestrially and possibly on other planetary bodies.

\section{BACKGROUND}

Little research has focused on fluid inclusions in gypsum. The few workers that made contributions to the knowledge of fluid inclusions in gypsum have concentrated on marine deposits. Early observations made by Sorby (1858) quickly dismissed fluid inclusions in gypsum due to the ease and readiness of gypsum to alter and transition to anhydrite. It was not until over a century later that Sabouraud-Rosset (1969) and Attia et al. (1994) demonstrated evidence of primary fluid inclusions in gypsum from Oligocene and Miocene coastal deposits. These studies were conducted to identify the source of the fluid as marine or non-marine. More recent studies have described gypsum precipitating from acid brines in Western Australia (Alpers et al., 1992; Benison et al., 2007; Bowen and Benison, 2013; Mann, 1988; McArthur et al., 1991); however a comprehensive study of fluid inclusions in the Western Australia gypsum has not yet been conducted. Other current studies include the very large gypsum crystals in the Cave of Swords found in the Naica Mine system of Mexico (Garcia-Ruiz et al., 2006). These gypsum crystals in the 
Cave of Swords do contain large fluid inclusions; however fluid inclusion studies have been limited due to the inhospitable conditions inside the cave, though experimental technologies to evaluate the fluid inclusions reliably are being developed (Krüger et al., 2013).

Geochemical concepts that govern the formation of salt-pan evaporites, that contain gypsum, have been discussed in the literature (e.g. Jones, 1966; Hardie and Eugster, 1970; Hardie et al., 1978; Eugster and Jones, 1979; Eugster, 1984; Lowenstein and Hardie, 1985) and later documented in case studies of continental evaporites (e.g. Alonso et al., 1991; Ericksen et al., 1976; Ericksen et al., 1977; Kunasz, 1978; Warren, 1982; Lowenstein, 1982; Ort'l et al., 1998). However, these studies have focused on moderate salinity and near-neutral to high $\mathrm{pH}$ water to identify economic deposits containing borates, sulfates, lithium, and other economic salts, including gypsum.

Natural acid brines are rare on Earth (Benison et al., 2007) and their suite of sedimentary and geochemical processes and products are complex and dynamic (Benison and Bowen, 2009, 2013). Little is know of the evolution of acid brines in volcanic basins. Volcanogenic acids have been documented elsewhere in the Andes (e.g., Varekamp, 2008; Varekamp et al., 2001) and in Indonesia (e.g., Sriwana et al., 2000), but they are not saline and do not produce an abundance of chemical sediments. This study of gypsum precipitating from acid volcanic Salar Ignorado may serve as a basis to conduct fluid inclusion studies of modern gypsum forming in other continental evaporite basins. 
Karmanocky, F. J. III, 2014

\section{Geologic Setting}

Salar Ignorado is situated in the Cordillera de los Andes at approximately $68^{\circ} 37^{\prime} 17^{\prime \prime} \mathrm{W}$ and $25^{\circ} 29^{\prime} 52^{\prime \prime} \mathrm{S}$ (Figure 1). Salar Atacama is located $230 \mathrm{~km}$ to the NNW and $\sim 1700 \mathrm{~m}$ lower in elevation than Salar Ignorado. Salar Ignorado is located on the southern edge of the Cerro Bayo volcanic complex $(5400 \mathrm{~m})$, which is composed of four stratovolcanoes (Gonzalez-Ferron, 1995). There is an older crater with andesitic lava flows on its west side, as well as a younger cone with a well-preserved crater, and two ridged lobes of dacitic lava flows, which has been dated at $1.6 \pm 0.4 \mathrm{Ma}$ using $\mathrm{K}-\mathrm{Ar}$ dating (Cornejo, 1987). Cerro Bayo and Salar Ignorado are found on the southern flank of the much larger, shallow to intermediate $(7-15 \mathrm{~km})$, Lastarria-Cordon del Azufre volcanic complex (Figure 1). Froger et al. (2007) determined the magma chamber is growing at a rate of $\sim 2.5 \mathrm{~cm} /$ year, via $\mathrm{InSAR}$ measurements, and have suggested that a shallow $(\sim 1000 \mathrm{~m})$ sealed hydrothermal system may be the major contributor to the inflation. The Cerro Bayo volcanic complex contains marginal deposits of native sulfur (Ferraris and Vila, 1987). Cornejo (1987) collected 18 rock samples of altered volcanic material near Ignorado and found an average of 45,000-ppm sulfur. Much of the volcanic country rock near Salar Ignorado has a washed or grey appearance, which has been attributed to hydrothermal alteration of the volcanic country rock (Figure 2A; Cornejo, 1987; Risacher, 2002). The immediate area surrounding Salars Ignorado and Gorbea contains several un-named volcanic features that can be seen from aerial imagery, however in detailed mapping of the various hydrothermal alteration facies has not been completed in the area surrounding Salar Ignorado. 
Karmanocky, F. J. III, 2014
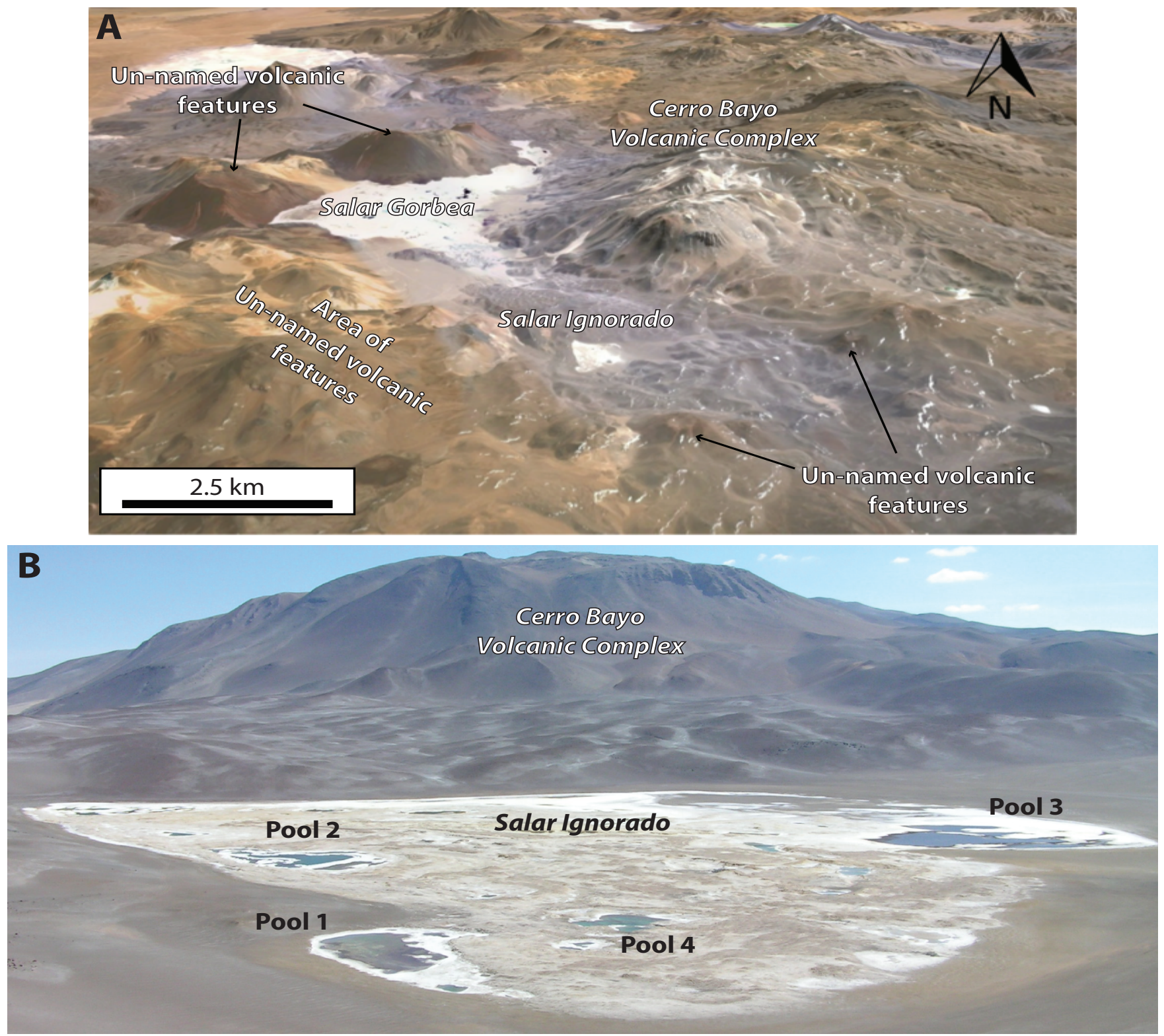

Figure 2. Imagery of the area surrounding Salar Ignorado and photograph of Salar Ignorado. (A) Google Earth image of Salars Gorbea and Ignorado are the two only known acid salars in the Andes, which are surrounded by volcanic features, most of which have not been positively identified, named, and their genesis remains largely unknown. The landscape near Salars Gorbea and Ignorado has a washed appearance, unlike that of the terrain off to the southwest and northeast. Risacher et al. (2002) and Cornejo (1987) attribute this discoloration to hydrothermal alteration of the host volcanic rock. (B) View of Salar Ignorado with Cerro Bayo in the background, note the uneven surface of the salar and the pools expressed in depressions carved in the salar surface (Photo courtesy of K. Benison). 
Karmanocky, F. J. III, 2014

\section{Environmental conditions}

The environment in this region is amongst the harshest on the planet with high winds, large dust devils, high solar radiation, and acid saline waters (Risacher et al., 2002; Benison and Gonzalez, 2007). The lack of precipitation and high evaporation rate creates one of the driest places on Earth. The region has experienced these harsh conditions at least since the Middle Miocene and they likely began as early as the Eocene (Stroez and Ericksen, 1974; Latorre et al., 2002). However, no climate data for the region exists. At the time of this study the closest weather station was located along the coast in Antofagasta, Chile, $\sim 250 \mathrm{~km}$ northeast of the study area and $\sim 4250 \mathrm{~m}$ lower in elevation. Field observations by Benison and Gonzalez (2007) in the late austral summer measured daytime temperatures that fluctuated from $1^{\circ} \mathrm{C}$ up to $25^{\circ} \mathrm{C}$. Risacher et al. (2002) estimates the annual mean temperature to be approximately $-2^{\circ} \mathrm{C}$.

Climate data from lower elevations in the Atacama Desert (Clarke, 2006; DGA, 1993; Houston, 2006; Kampf et al., 2005) to the west of the Cordillera de los Andes can be used to estimate the climate at Salar Ignorado. The area is a glacier-free, despite the high elevation with no influent or effluent stream and the surface water is limited to highly localized surface pools on the salar surface. There is no vegetation and no true soil in the field area. Surface sediments are either volcaniclastics or salts. Much of the salts are efflorescent salt crusts that form during evaporation of shallow groundwater wicked up to the surface in very dry conditions indicative of high evaporation rates. Measurements of evaporation rates as high as 2.8 millimeters/day have been made for the Salar de Atacama (Kampf et al., 2005) and could potentially be as high as 10 millimeters/day at Salar Ignorado (Risacher et al., 2002). 
Karmanocky, F. J. III, 2014

\section{Salar Sedimentology}

Salar Ignorado is a subaerially-exposed, salt-covered expanse with unusually lowrelief compared to the surrounding topography. However, salars are not perfectly flat, but have a hummocky topography with a relief of $\sim 2$ meters. The surface of the salar flat in the depressions between the hummocks is composed of white and yellow efflorescent salts (Figure 3A and 3B). These are finely-crystalline and have a popcorn-like texture in mounds. The hummocks are distinguished, besides topographic relief, by a tan color (Figure 3C). The hummock surfaces are composed of a salt crust overlain by varying amounts of loose silt, sand, and gravel, most of the clasts are gypsum (Figure 3D). Sulfate chemical sediments with minor amounts of chlorides, iron oxides, and siliciclastics dominate the Salar Ignorado salt flat. Surface white and yellow crusts (Figure $3 \mathrm{~A}$ and $3 \mathrm{~B})$ contain the minerals gypsum $\left(\mathrm{CaSO} 4 \cdot 2 \mathrm{H}_{2} \mathrm{O}\right)$, halite $(\mathrm{NaCl})$, jarosite $\left(\mathrm{KFe}_{3}\left(\mathrm{SO}_{4}\right)_{2}(\mathrm{OH})_{6}\right)$, epsomite $\left(\mathrm{MgSO}_{4} \cdot 7 \mathrm{H}_{2} \mathrm{O}\right)$, bassanite $\left(2 \mathrm{CaSO}_{4} \cdot \mathrm{H}_{2} \mathrm{O}\right)$. Loose silt, sand, and gravel on the hummocks are mostly gypsum clasts (Figure 3D; Benison and Gonzalez, 2007).

At Salar Ignorado, groundwater is at depths of $10-20$ centimeters below the salt flat and water temperatures ranged from -1 to $24^{\circ} \mathrm{C}$. At Salar Ignorado, groundwater $\mathrm{pH}$ and salinity ranged from $4.0-4.6 \mathrm{pH}$ and 5 - $30 \%$ TDS. In coarse sediment, composed mostly of plagioclase and quartz, alunite is found in close association with minor jarosite and hematite as isopachous intergranular cement. In finer-grained sediments, alunite is common with some plagioclase. Cream-colored kaolinite is also found in these alunite mud sediments. Alunite, kaolinite, jarosite, and hematite cements all form localized patches in the shallow subsurface (Benison and Gonzalez, 2007). 
Karmanocky, F. J. III, 2014
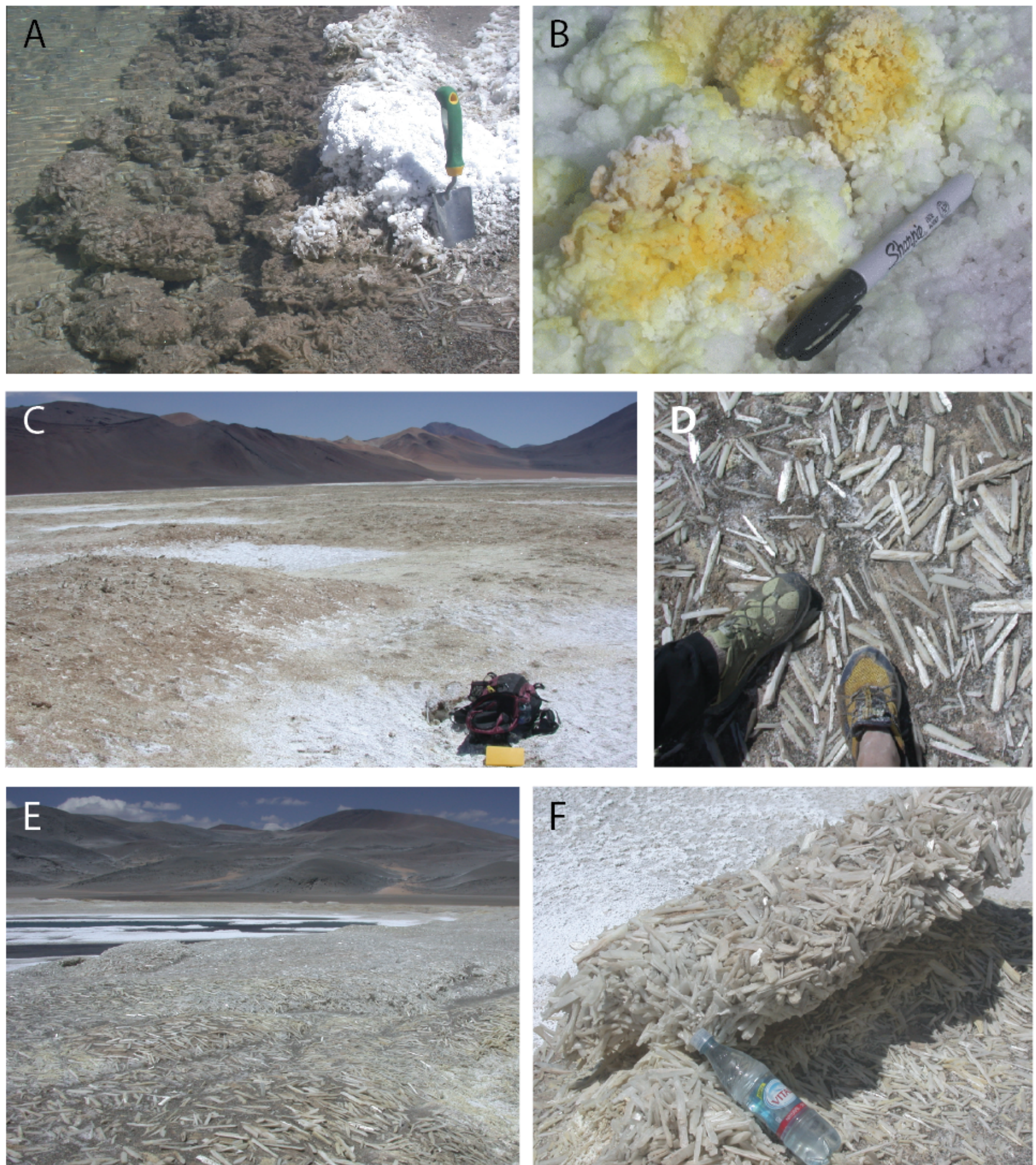

Figure 3. Salts at Salars Ignorado and Gorbea. (A) Mounds of gypsum precipitating from acid saline Salar Ignorado pool water and efflorescent crust of halite near the shovel, in (B) efflorescent crusts are composed of both halite and native sulfur. (C) Undulating, hummocky surface of the salar, composed of gypsum with efflorescent crusts of halite in the depressions. (D) Close-up of the gypsum on the salar surface bound by a matrix of fine grained material. (E) and (F) are examples of what the strong winds in te region are capable of, $(E)$ is a dune made of gypsum, similar to $(D)$ and $(F)$ is a gypsum breccia. The gypsum breccia formed as a result of gypsum crystals being rolled across the salar surface and are cemented together with efflorescent salts (Photos courtesy of K. Benison). 
At Ignorado, small dune ridges make up much of the topography of the salar and the dune crests there serve as subaerially exposed area between the salar pools, which appear to be situated in blowout depressions (Figure 3E). Salar Ignorado eolian grains are large gypsum crystal clasts that form a gypsum breccia (Figure 3F) are commonly cemented by gypsum at the surface.

\section{Acid Saline Pools}

The salar flats are punctuated with shallow pools of surface water. These salar pools range in size from $\sim 2 \mathrm{~m}$ to $\sim 50 \mathrm{~m}$ in diameter and are $0.1 \mathrm{~m}$ to $1 \mathrm{~m}$ deep. Typical volcanic lake systems are stratified (Pasternack and Varenkamp, 1997). However, no stratification was observed in the pools of Salar Ignorado. Field measurements of water chemistry (temperature, salinity, and $\mathrm{pH}$ ) were gathered at five pools by Risacher et al. (2002) and at four pools by Benison (personal communication). Salar Ignorado surface and ground waters range in $\mathrm{pH}$ from 2.6-4.6 and have salinities that range from 5-30 ppth TDS (Table 1). Risacher et al. (2002) employed various analytical techniques to measure concentrations of ions in solution from five sampled pools (See Appendix B for a complete list of concentrations). Salar Ignorado waters are $\mathrm{SO}_{4}$ and $\mathrm{Na}$ rich, with lesser amounts of $\mathrm{Mg}, \mathrm{Cl}, \mathrm{K}, \mathrm{Al}$, and $\mathrm{Ca}$ (listed by abundance; Risacher et al., 2002). 
Karmanocky, F. J. III, 2014

Table 1 Field measurements made at Salar Ignorado in March 2007, ns = no sample collected. Courtesy of K. Benison.

\begin{tabular}{c|c|c|c|c|c}
\hline Site & $\begin{array}{c}\text { Pool } \\
\text { Water } \\
\text { Depth } \\
\text { (cm) }\end{array}$ & $\begin{array}{c}\text { Depth to } \\
\text { Groundwater } \\
(\mathbf{c m})\end{array}$ & Field pH & $\begin{array}{c}\text { Total } \\
\text { Dissolved } \\
\text { Solids (ppth) }\end{array}$ & $\begin{array}{c}\text { Temperature } \\
\text { ( } \mathbf{0} \text { () }\end{array}$ \\
\hline Pool 1 & $10-30$ & 20 & 4.1 & 15 & 9 \\
Groundwater 1 & $10-20$ & 20 & 4.1 & 20 & 13 \\
\hline Pool 2 & & 4.6 & 10 & 7 \\
Groundwater 2 & $10-100$ & 10 & 4.0 & 5 & 15 \\
\hline Pool 3 & & & 3.3 & 15 & 5 \\
\hline Groundwater 3 & $10-30$ & $\mathrm{~ns}$ & $\mathrm{~ns}$ & $\mathrm{~ns}$ & 13 \\
\hline Pool 4 & & & & & $\mathrm{n}$ \\
\hline
\end{tabular}

\section{METHODS}

\section{Sample preparation}

Gypsum crystals were prepared in the lab for petrographic and fluid inclusion study with a razor blade and abrasives. Cleaved thin slices of gypsum can be achieved by uniformly cutting cleavage fragments along the (010) plane as thinly as possible with a razor blade. Samples that were too fragile to cut with a razor blade were polished to thickness with sandpaper (up to 3000-grit). Critical preliminary petrographic observations were made during this process to ensure the fluid inclusions were not compromised and the sample was the proper thickness. Without this control the fluid inclusions may have been breached, altered, or decrepitated. 
Karmanocky, F. J. III, 2014

\section{Petrographic observations}

Three petrographic microscopes were used for this study: (1) Olympus SZX10 binocular microscope with plane transmitted, reflected and polarized light, and magnification of $6.3 \mathrm{x}$ to $63 \mathrm{x}$; (2) Olympus BX53 petrographic microscope with plane transmitted and polarized light, and magnification of 20x to 400x; (3) Olympus BX53 microscope with plane transmitted, reflected, polarized, and UV-vis light sources, and magnification of 20x to 2000x. These microscopes are equipped with digital imaging and SPOT 5 digital imaging software.

Petrographic observations of the gypsum from Salar Ignorado documented liquid, gas, solid, and organic contents within fluid inclusions. Each inclusion was also scrutinized to ensure that they had not leaked, reequilibrated, or had been compromised since the time of entrapment. Fluid inclusions within the gypsum crystals were characterized by the consistency of ratios of the phases present within individual fluid inclusion assemblages.

Fluid inclusions within a gypsum sample were grouped into different fluid inclusion assemblages (FIAs). Fluid inclusions that were all trapped at the same time are referred to as an FIA (Goldstein and Reynolds, 1994). This means that an FIA defines the most finely discriminated trapping event that can be identified based on petrographic observations (Goldstein, 2003). For example, a group of fluid inclusions oriented along a growth band, parallel to a crystal face is considered a primary FIA and would be interpreted as remnants of parent waters from which the crystal grew. In contrast, a group of fluid inclusions that cross-cuts growth bands would be considered secondary or pseudosecondary FIA and interpreted as a healed microfracture. Isolated inclusions or 
fluid inclusions of unknown origin were identified and designated as IDKs (or "I don't knows"). Petrographic observations were used to help determine which primary FIAs were analyzed using microthermometry and laser Raman spectroscopy.

Fluid inclusion liquid to vapor ratios $(\mathrm{L}-\mathrm{V})$ were evaluated across the primary FIAs. Identifying the ratio of liquid to vapor trapped in a fluid inclusion can indicate the environmental conditions in which the gypsum formed (Goldstein and Reynolds, 1994). If an FIA contains fluid inclusions that are all liquid, then it can be concluded that those inclusions were trapped under low temperature conditions $\left(\mathrm{T}<50{ }^{\circ} \mathrm{C}\right)$ from the phreatic zone, or below the water table. However, if a primary FIA contains inclusions of varying $\mathrm{L}-\mathrm{V}$, some inclusions have the potential to contain all liquid, all vapor, or a ratio in that range. A variety of $\mathrm{L}-\mathrm{V}$ ratios indicates that the environment was low temperature $(\mathrm{T}<$ $50{ }^{\circ} \mathrm{C}$ ) and in the vadose zone, located above the water table. Petrographic observations of the L:V ratio will only work if the vapor phase is of the liquid, but if they are not a true liquid and vapor phase, rather a liquid and gas phase, then this approach will not work. The presence of a gas would imply the fluid inclusion formed during a time of degassing. All-liquid inclusions can form as a byproduct of fluid inclusions necking-down. Necking-down occurs when a single fluid inclusion separates into several fluid inclusions. Fluid inclusions with irregular shapes are unstable and attempt to reduce their surface free energy by forming smaller circular or negative crystal shapes through dissolution and reprecipitation (Roedder, 1984). Necked fluid inclusions can still be used as part of a freezing-melting microthermometry study since the process of necking does not affect the major ions in solution (Goldstein and Reynolds, 1994). 
Any features other than liquid and vapor trapped in fluid inclusions that were not intrinsic to the colorless gypsum crystal, resembled microorganisms, and/or organic compounds were documented. Transmitted light and UV-epi-illumination at the highest magnifications were used to observe organic material (e.g. Burruss, 2003; Goldstein, 2003) or microorganisms in fluid inclusions. Criteria for identifying microorganisms were established by consulting observations made in the literature (e.g. Schubert et al., 2009; Lowenstein, 2012; Conner and Benison, 2013; Benison and Karmanocky, 2014). UV-vis light at 330 and $385 \mathrm{~nm}$ can be absorbed and cause electrons in the outermost shell of a molecule to be excited. Photons are emitted as light at longer wavelengths than the excited UV-vis wavelengths (330 $\mathrm{nm}$ and $385 \mathrm{~nm}$ ), when electrons in the molecule return to their ground state with a byproduct of fluorescence. The color of fluorescence indicates the wavelength of the light emitted from the organic molecule in response to its interaction with the UV-vis light.

\section{Crushing for odor test}

Samples with large or anomalous vapor bubbles were scrutinized for their composition. Qualitative analysis included a "crush-and-sniff" method that noted any detectable odors. Samples with anomalous vapor bubbles were carefully cut with a razor blade to the immediate shape of the fluid inclusion in question. This was done to alleviate the possibility that adjacent fluid inclusion assemblages would contribute additional odors or dilute the present odors in the experiment.

Single samples were placed in a sanitized mortar and pestle, crushed, and odors were immediately evaluated via olfactory system. Description of the odor was documented and described. Due to potential, and likely, exposure to hydrogen sulfide 
$\left(\mathrm{H}_{2} \mathrm{~S}\right)$, only one sample could effectively be run through the "crush-and-sniff" method per day. $\mathrm{H}_{2} \mathrm{~S}$ gas olfactory fatigue and ability to identify additional $\mathrm{H}_{2} \mathrm{~S}$ is diminished, so only one sample was evaluated in a 24-hour period.

\section{Microthermometry}

Microthermometry conducted on primary fluid inclusion assemblages in gypsum samples from Salar Ignorado included freezing-melting runs on a FLUID Inc. USGS adapted gas flow heating-freezing stage mounted on the Olympus BX53 microscope at West Virginia University (lab of Kathleen C. Benison). The thermocouple of the stage was calibrated to $0.0^{\circ} \mathrm{C}$ using an ice bath standard (FLUID Inc. calibration guidelines) and to $-56.6^{\circ} \mathrm{C}$ using a synthetic $\mathrm{CO}_{2}$ fluid inclusion. Freezing-melting studies were used to determine the salinity and major elements in the parent water (Goldstein and Reynolds, 1994). Liquid nitrogen was pumped through the fluid inclusion stage to freeze the fluid inclusions. After the fluid inclusion was frozen, it was slowly warmed. During warming, identification of different phases (solid, liquid, and vapor; see Figure 11) and the temperature at which each phase forms or disappears was documented and photographed.

\section{Laser Raman spectroscopy}

Raman spectra were acquired with a JY/Horiba LabRam HR Raman system (housed at the USGS - Reston, VA lab of I-Ming Chou and Robert Burruss), using 532 $\mathrm{nm}$ laser excitation. Laser Raman spectroscopy is a non-destructive technique that detects covalently bonded compounds through detection of vibrational energies. This technique allows chemical characterization of solids, liquids, and gases as small as $1 \mu \mathrm{m}$, depending on the focus of the instrument. Laser Raman spectroscopy was used to: 1) document organic compounds, 2) identify specific covalently bonded compounds in 
inclusion fluids, and 3) identify accessory minerals trapped within gypsum crystals and fluid inclusions. Laser Raman spectroscopy was also used to attempt to identify the composition of the vapor bubbles within the fluid inclusions.

\section{RESULTS}

\section{Petrography of Salar Ignorado Gypsum}

Two primary growth morphologies of gypsum include: (1) mounds of 'needleshaped', or acicular, gypsum (similar in appearance to a sea urchin) and (2) larger 'stockwork' masses of reworked bottom-growth prismatic/hemi-bipyramidal crystals of various orientations (Figure 4).

Tiny needle-like gypsum crystals (Figure 4A) have been observed to be a maximum of $7 \mathrm{~cm}$ in length and $1.5 \mathrm{~cm}$ wide, but most are quite small, averaging $\sim 4 \mathrm{~cm}$ long and $\sim 1 \mathrm{~cm}$ wide. These gypsum crystals tend to grow with the crystals radiating from a similar central point. Mounds of semi-transparent needle shaped gypsum crystals were collected from the bottom of the pools, below the air-water interface. Primary FIAs in 'needle'-shaped gypsum indicate the growth faces of the gypsum crystals and form at an oblique angle to the twinned (101) crystal face. 'Needle-shaped' crystals also host secondary and pseudo-secondary FIAs.

Large bladed gypsum crystals, that are prismatic/hemi-bipyramidal, (Figure 4B) are much larger than the tiny needle-like gypsum and measured to be up to $\sim 21 \mathrm{~cm}$ long and $3 \mathrm{~cm}$ wide. These crystals were likely precipitated as bottom growth gypsum crystals then deposited and cemented together by white, finely-crystalline gypsum cement. Primary FIAs line the crystal growth face and occur normal to the (103). 'Stock-work' crystals can also host secondary and pseudo-secondary FIAs. 


\section{Fluid inclusion petrography}

Primary fluid inclusions in both needle-shaped and stock-work gypsum are aligned in rows parallel to the direction of growth (Figure 5). Primary inclusions point in the direction of growth with the fluid inclusion broadest at its base and tapering upward. Three types of primary FIAs can be identified petrographically:

The Type I primary fluid inclusions (Figure 6A) are triangular-shaped in twodimensional space and typically consist of groups of 2 or 3 (Figure 6A1) and can be quite large $(\sim 50$ to $200 \mu \mathrm{m})$. There can be some difficulty in discerning Type II fluid inclusions from fluid inclusions of unknown origin or IDKs. Type I primary fluid inclusions are oriented parallel to crystal faces (Figure 6A2). The large, Type I primary fluid inclusions tend to have an obtuse-scalene-triangular morphology that points in the direction of crystal growth and the base of the fluid inclusion is parallel to the growth plane. While IDKs display similar features, they cannot be evaluated due to the unknown nature of their genesis. Type I primary fluid inclusions have considerable variation in the L-V ratio and some trap microorganisms such as Dunaliella algae, diatoms (Figure 6A3), and organic compounds (Figure 6A1). 
Karmanocky, F. J. III, 2014
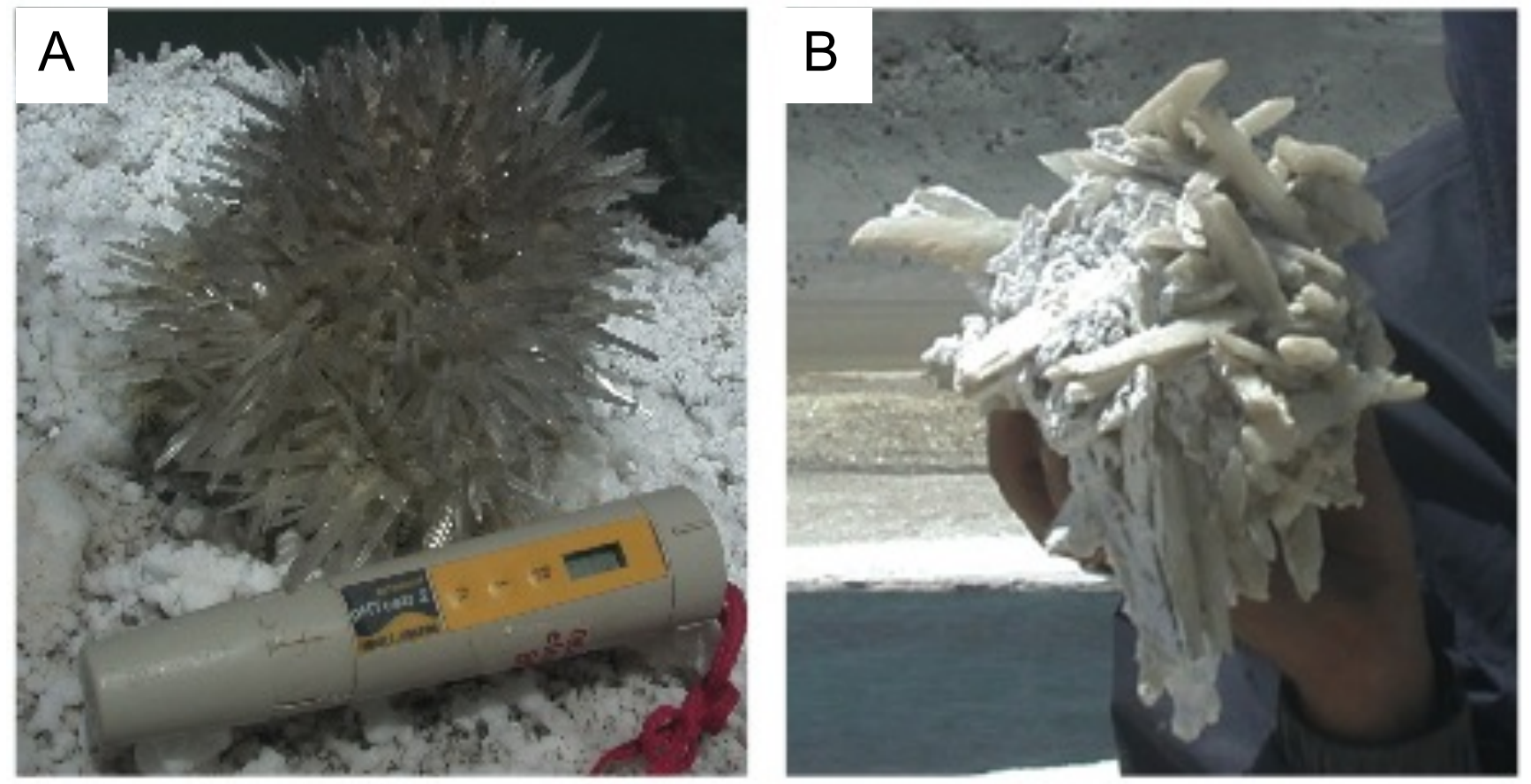

Figure 4. Gypsum crystal morphologies from Salar Ignorado. (A) 'Needle-shaped' acicular mounds of gypsum that have a similar appearance to a sea urchin, and (B) stock-work' masses of prismatic/hemibipyramidal selenite crystals that form in random orientations (Photos courtesy of K. Benison). 

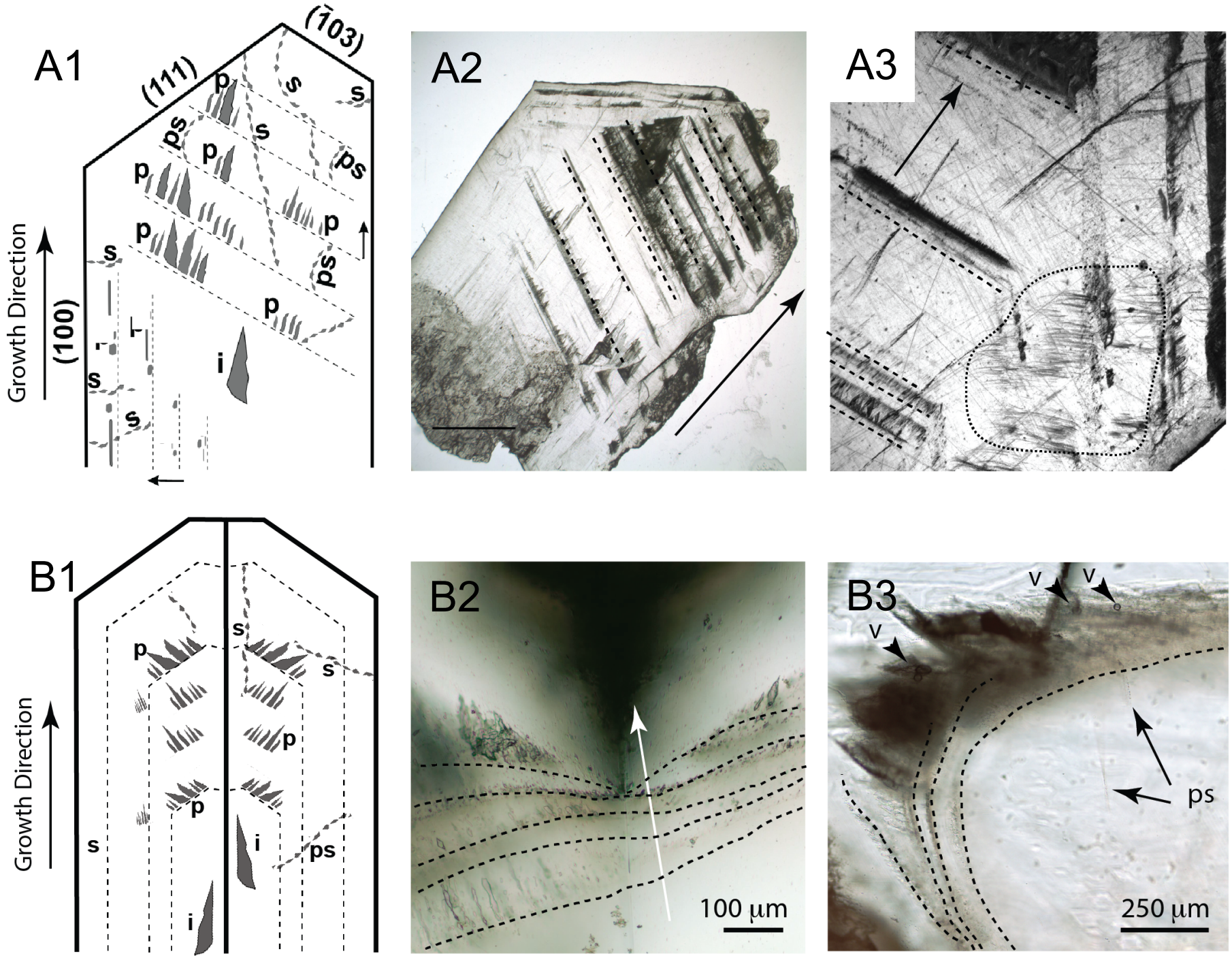

Figure 5. Fluid inclusions petrography of stock-work and needle-shaped gypsum crystals. Schematic drawings of $(A)$ stock-work and (B) needle shaped crystals that illustrate the relationships primary (p), secondary (s), psuedosecondary (ps), and isolated (i) inclusions have to the crystal morphology. In (A2) former growth faces of gypsum are indicated by dashed lines and primary fluid inclusions appear as dark bands and point in the direction of crystal growth, also indicated by the arrow. (A3) is a closer image and some of the secondary and psuedosecondary inclusions become more obvious. A swarm of psuedosecondary inclusions is outlined by a dotted line, note how they terminate at former crystal faces. (B2) Primary fluid inclusions in stock-work crystals also form parallel to growth planes and point in the direction of growth, indicated by the white arrow. The primary fluid inclusions in (B2) are located near the middle of the crystal, whereas those in (B3) are located near the outer edge of the crystal. (B3) Examples of two psuedosecondary fluid inclusion assemblages that likely terminated at a crystal face at an earlier time in the growth of this gypsum crystal, also note the anamolously large vapor (?) bubbles indicated by an arrow. 
Type II primary inclusions (Figure 5B) range in size from $\sim 2$ to $15 \mu \mathrm{m}$ long and are sub-horn shaped in two-dimensional space. Type II primary fluid inclusions typically form in groups of 10 to 25 fluid inclusions; however, in some cases the number of fluid inclusions can be indiscernible (Figure 6B1; Figure 6B2). Type II primary fluid inclusions L-V (or gas) ratios are highly variable. Some of these inclusions also trap microorganisms and organic compounds. In 'needle'-shaped gypsum crystals Type II fluid inclusions form at oblique angles to the (101) twinning plane and can even appear to curve toward the (101) twinning plane (Figure 4).

Type III primary fluid inclusions (Figure 6C) are horn-shaped in two dimensional space and form in groups of 4 to 35 and are intermediate in size, ranging in size from $\sim 20$ to $60 \mu \mathrm{m}$, and are consistently all liquid (Figure 6C1). These fluid inclusions also trap sediment, microorganisms (Figure 6C2) such as diatoms and carotenoids, and organic material. Type III fluid inclusions have only been documented in needle-shaped gypsum.

Secondary FIAs occur as linear or curved trails that can cross cut many generations of primary FIAs and terminate at the crystal face (Figure 7A). Secondary fluid inclusions range in size but are typically 2 to $10 \mu \mathrm{m}$ long and have a variety of shapes; most have shapes of negative crystal to sub-cubic, yet some can be triangular. Secondary fluid inclusions have inconsistent and varying L-V ratios. A second type of secondary fluid inclusions includes large amorphous fluid inclusions that lack any consistent shape or arrangement (Figure 7B). These inclusions are located along the cleavage planes of the gypsum crystal and are very thin, perhaps less $1 \mu \mathrm{m}$. Secondary fluid inclusions trap liquid, vapor, gasses, microorganisms, and other debris found in the pool water. 
Karmanocky, F. J. III, 2014
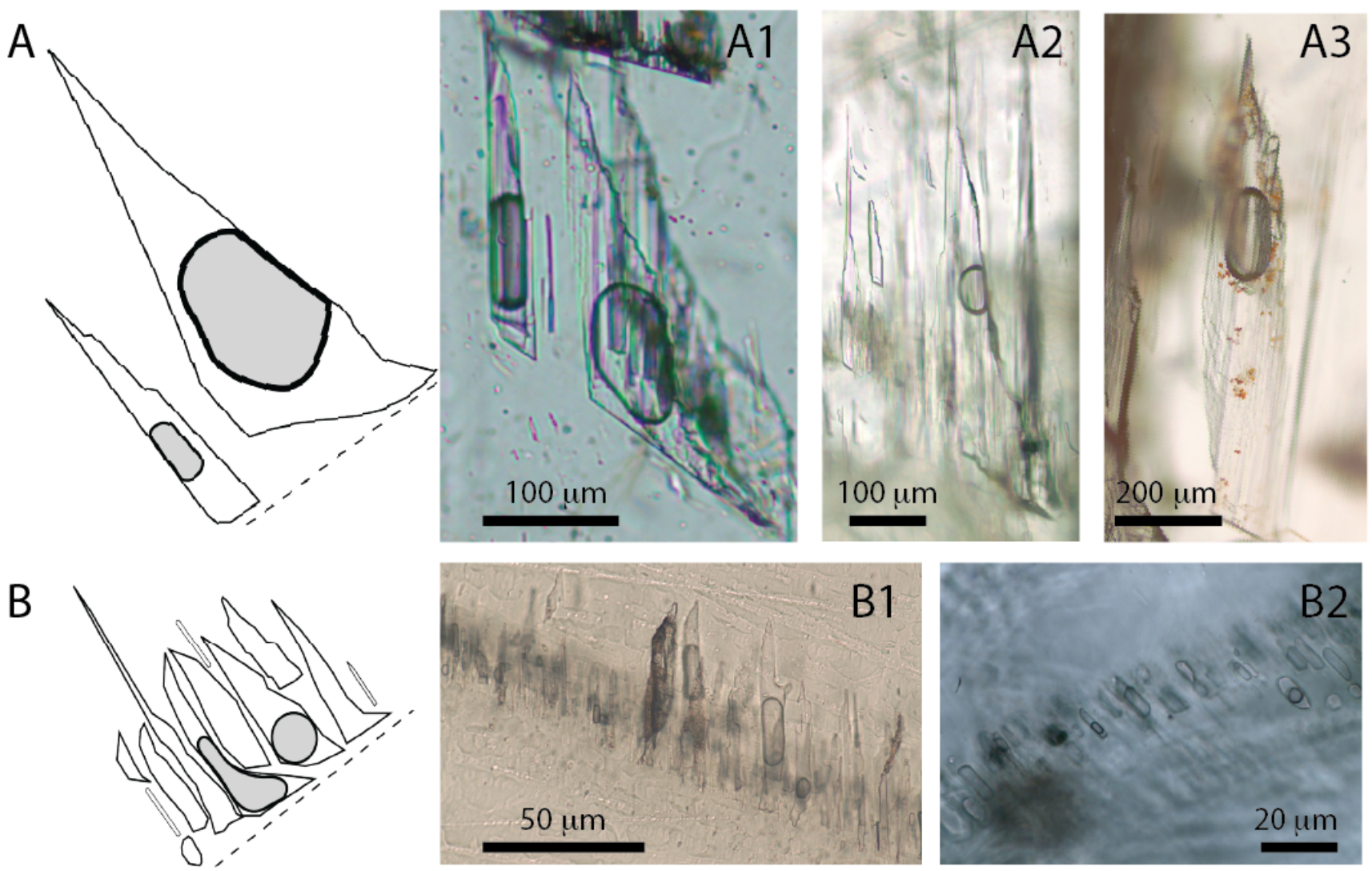

C
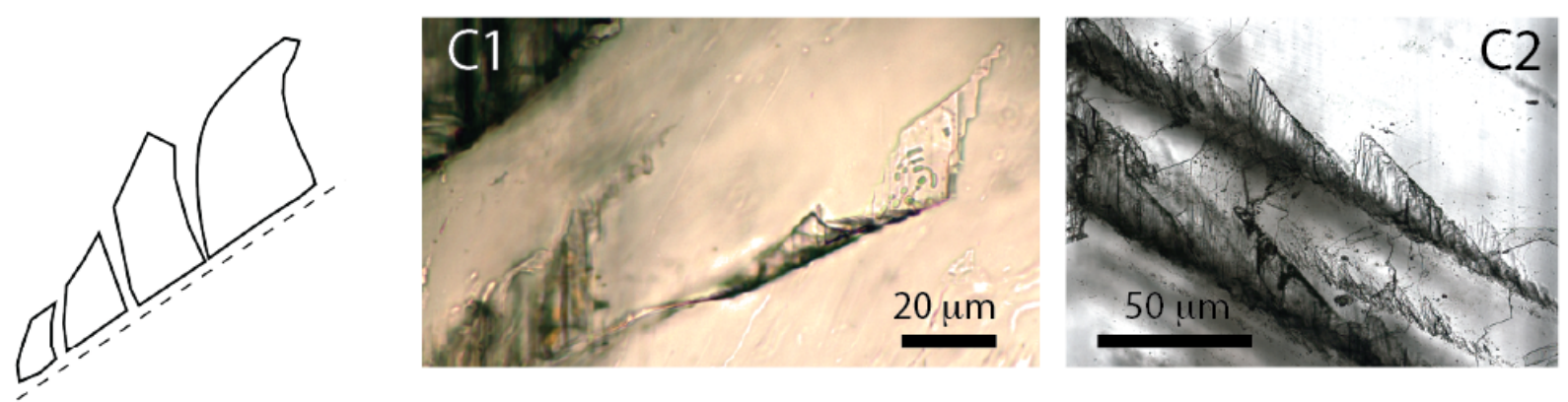

Figure 6. Primary fluid inclusion types. (A) Schematic drawing of Type I primary fluid inclusions with examples in (A1), (A2), and (A3), are similar in shape, but much larger than Type II primary fluid inclusions in (B1) and (B2). Note the inconsistent $L-V$ ratios in $(A)$ and $(B)$, whereas $(C)$ are consistently all liquid with examples in (C1) and (C2). See text for a detailed explanation of each. 
Karmanocky, F. J. III, 2014
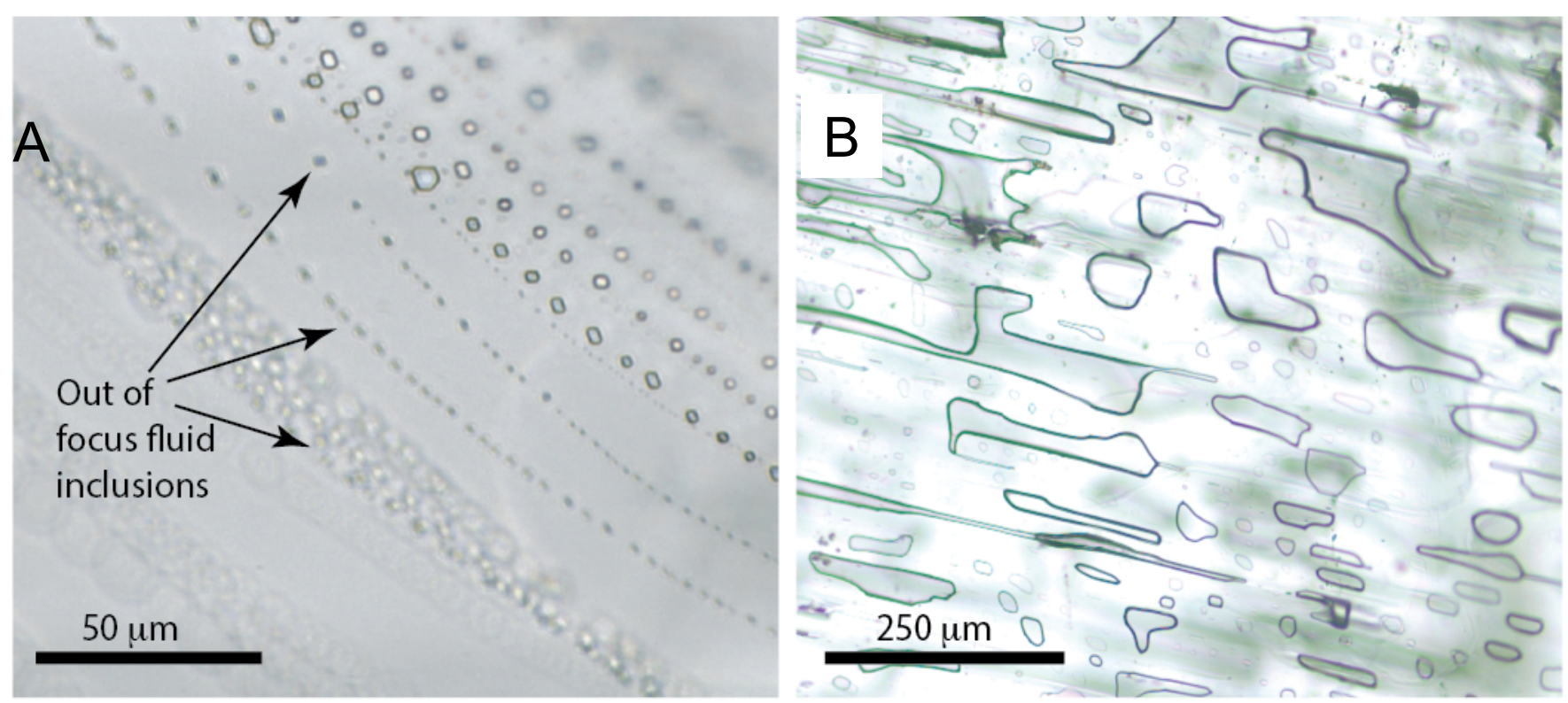

Figure 7. Secondary fluid inclusions in Salar Ignorado gypsum. (A) Secondary fluid inclusions that resulted from the healing of a microfracture in the gypsum crystal, whereas (B) are secondary fluid inclusions that exist between the cleavage planes of the gypsum. No microthermometry or laser Raman analyses were done on secondary fluid inclusions. 
Pseudo-secondary FIAs share similar morphologies as secondary FIAs, however pseudo-secondary FIAs terminate at a previous growth face within the crystal. The pseudo-secondary inclusions tend to be negative crystal to cubic in shape and range from $\sim 2$ to $8 \mu \mathrm{m}$ long.

\section{Solid Inclusions in Gypsum}

Pennate diatoms are trapped as clusters in primary fluid inclusions and solid inclusions (Figure 8). Clusters contain either (1) pristine diatoms, suggesting entrapment of live diatoms; or (2) abundant broken diatoms, indicating abrasion during wind transport and physical deposition in salar pools prior to entrapment by the growing gypsum (Figure 8C). Discrete parts of pristine diatoms, likely their chloroplasts, fluoresce blue when exposed to UV-vis light (Figure 8B1 and 8B2).

Suspect green algae are abundant in Salar Ignorado gypsum (Figure 9A1, 9C1, 9D). They appear as pale yellow and pale orange dimpled spheres and ovoids that fluoresce blue (Figure 9A2 and 9C2), range in size from $\sim 3-10 \mu \mathrm{m}$, and are observed both as solid inclusions and in fluid inclusions. Multiple spheres and ovoids, likely Dunaliella alga (Figure 9B1), are typically found together, with as many as $\sim 20$ in some individual primary fluid inclusions, and are trapped in the gypsum crystal (Figure 9E).

Prokaryotes are observed both as solid inclusions and within some fluid inclusions. They appear as clear, high relief, 1-2 $\mu \mathrm{m}$ diameter spheres and pale yellowclear (Figure 9B1), high relief, 4-5 $\mu \mathrm{m}$ long rods. All fluoresce pale green when exposed to UV-vis light (Figure 9B2). Some of these coccoid and bacilli-shaped cells are likely bacteria and/or archaea (e.g. Mormile et al., 2003; Schubert et al., 2010). 
Karmanocky, F. J. III, 2014
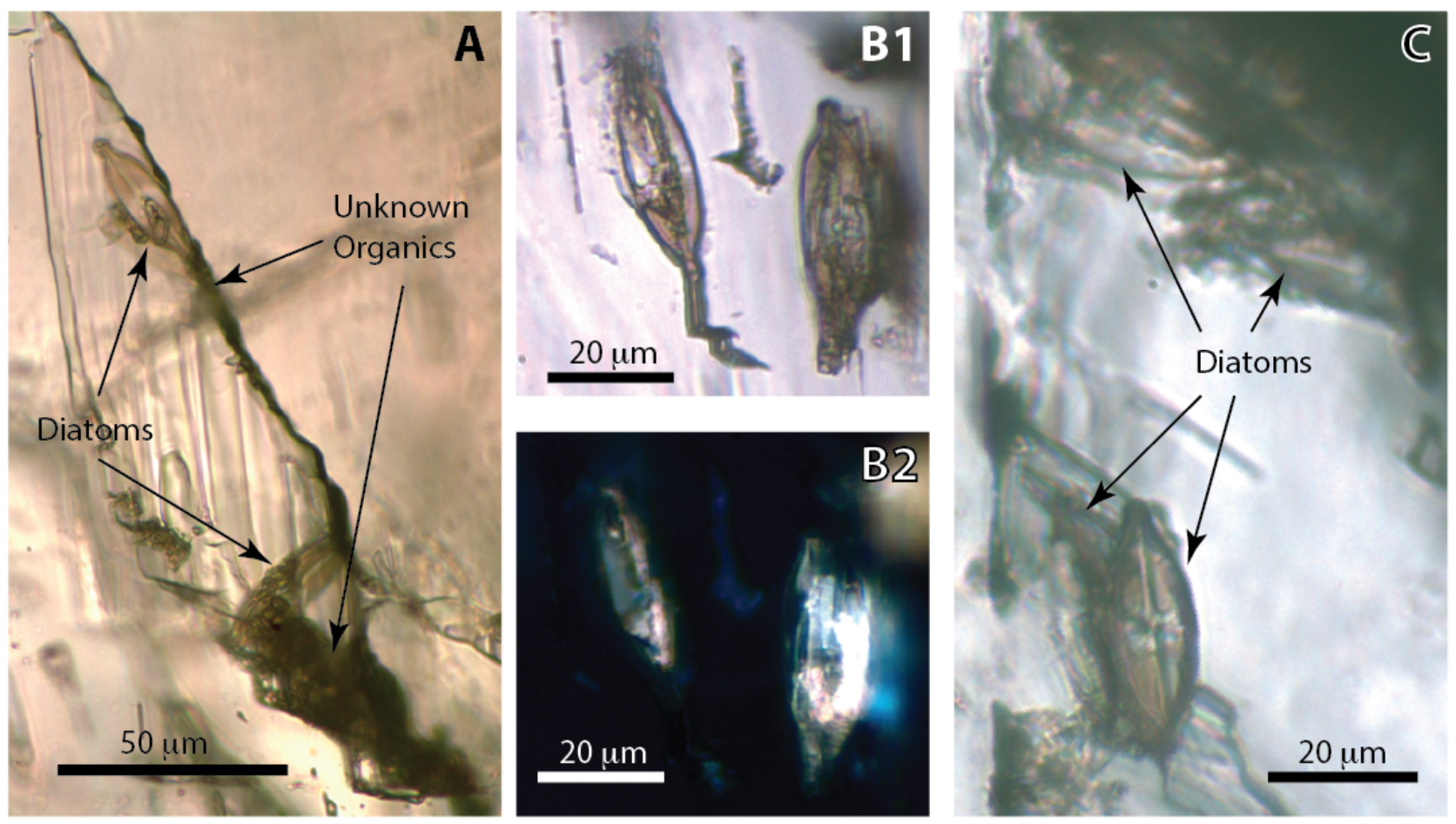

Figure 8. Pennate diatoms in Salar Ignorado gypsum. (A) Pennate diatoms trapped in a Type III primary fluid inclusion. (B1) Diatoms trapped in gypsum in plane polarized light and (B2) is the same field of view as (B1) exposed to UV-vis. (C) Pennate diatoms that have been transported, likely by wind. The most prominent diatom in the lower left is in good condition, however the diatoms in the upper right have undergone a significant amount of abrasion and are disarticulated. 
Karmanocky, F. J. III, 2014
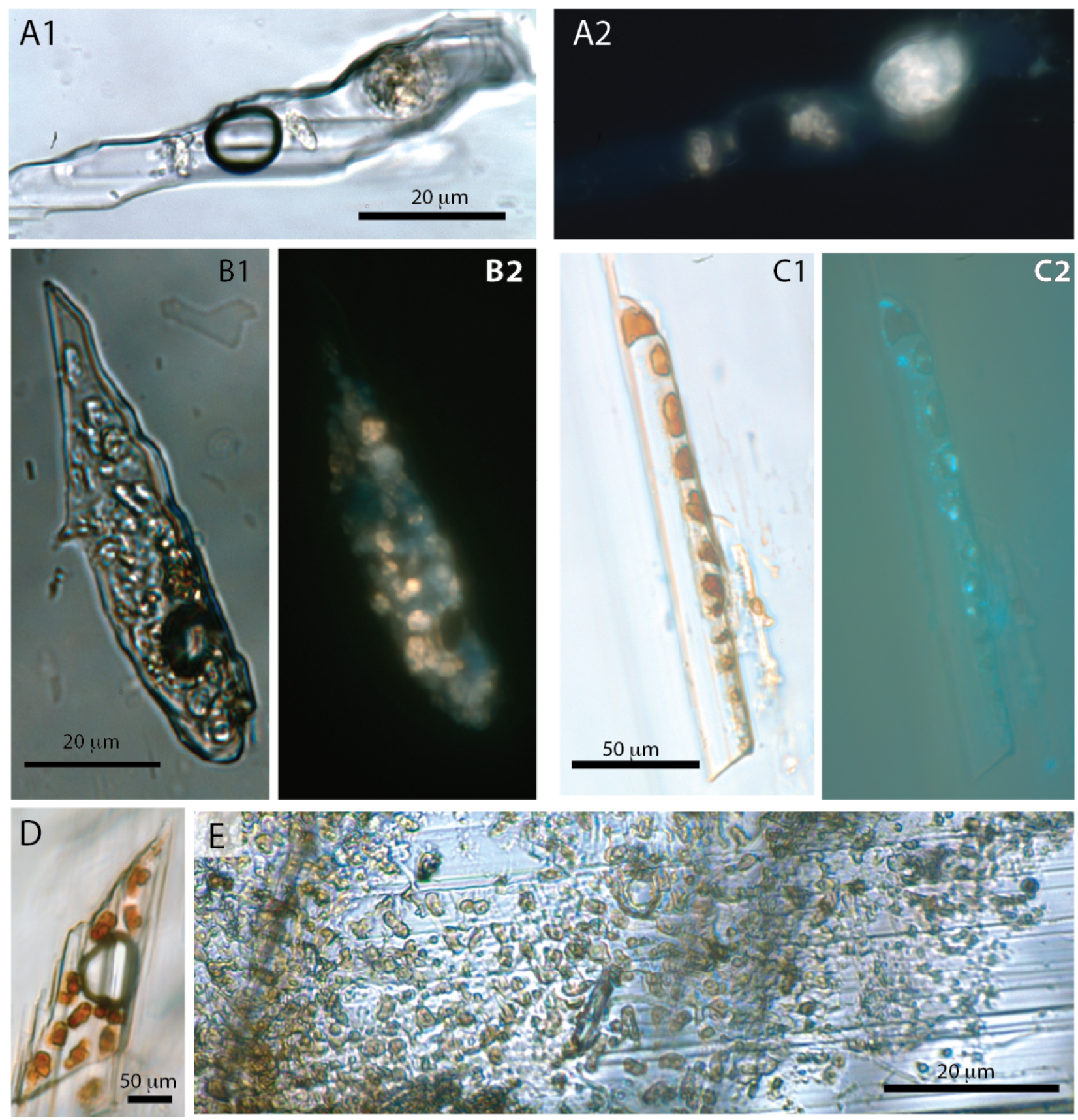

Figure 9. Microorganisms trapped in fluid inclusions and host gypsum. 
Karmanocky, F. J. III, 2014

\section{Laser Raman spectroscopy}

Solid inclusions, as well as primary fluid inclusions were evaluated with laser Raman spectroscopy. When the laser was focused on the fluid within a primary fluid inclusion, the resulting Raman spectra was that of the host gypsum crystal with peaks at 179, 415, 493, 619, 670, 1009, and 1136 (Figure 10D; lower blue line). Exposure time and intensity was increased, however the resulting Raman spectrum was that of the host gypsum.

Some primary fluid inclusions contained 1-3 $\mu \mathrm{m}$ spherical solids (Figure 10A). These are typically clear, but in some cases have a green hue in transmitted light and can be a bright blue in UV light. They collect in lineations (Figure 10C) or in clusters (Figure 10B). Laser Raman spectroscopy excitation shows that these spherical solids are high molecular weight, alkane-rich hydrocarbons (Burruss, personal communication) (Figure 10D; upper black line).

\section{Microthermometry of primary fluid inclusions}

Primary fluid inclusions were frozen at temperatures between $-137^{\circ} \mathrm{C}$ and $-90^{\circ} \mathrm{C}$. Some inclusions were difficult to determine the freezing point of the liquid phase and multiple freezing-melting runs were required to discern the initial freezing phase change. Upon freezing, the fluid(s) in the inclusions transitioned from clear to dark brown and has a slightly grainy texture, in some cases a color change was difficult to discern; however, the edges of a vapor bubble, if present, would become irregular and jagged (Figure 11 at $98^{\circ} \mathrm{C}$ and Figure 12 at $-92.7^{\circ} \mathrm{C}$ ). The irregularity in the shape of the vapor bubble is a response to the freezing and subsequent expansion of the fluid in the inclusion. 
After the inclusion was completely frozen, usually between $-137^{\circ} \mathrm{C}$ and $-90^{\circ} \mathrm{C}$, it was slowly warmed. Changes in the color, shape, texture, and apparent constituents were documented during warming. The eutectic temperature $\left(\mathrm{T}_{\mathrm{eu}}\right)$ or the temperature at which the first melting occurs, of 125 fluid inclusions was recorded to be between $-62.4^{\circ} \mathrm{C}$ and $20^{\circ} \mathrm{C}$, with an average of $-40.9^{\circ} \mathrm{C}$. The majority of the $\mathrm{T}_{\text {eu }}$ 's were measured between $50.2^{\circ} \mathrm{C}$ and $-30.1^{\circ} \mathrm{C}$ (Figure 12). Eutectic temperatures varied $0.7^{\circ} \mathrm{C}$ to $13.9^{\circ} \mathrm{C}$ across a FIA and were reproducible to within $\pm 1.2^{\circ} \mathrm{C}$.

Continued warming of the primary fluid inclusions would result in final melting. The only phase that could confidently be identified was ice $\left(T_{m}\right.$, ice). The final melting temperature of ice of 125 fluid inclusions ranged from $-28^{\circ} \mathrm{C}$ to $-0.9^{\circ} \mathrm{C}$, and averaged $12.7^{\circ} \mathrm{C}$. Salinity was calculated using the equation of Bodnar (1992; Equation 1) to determine the salinity of the inclusions in $\mathrm{NaCl}$ equivalent salinity:

$$
\text { Salinity (eq. wt. } \% \mathrm{NaCl})=0.00+1.78 \Theta-0.0442 \Theta^{2}+0.000557 \Theta^{3} \text {. (1) }
$$

where $\Theta$ is the temperature in degrees below zero. This equation, based on a least squares regression of measurement in the $\mathrm{NaCl}$ system provides precision of \pm 0.05 eq. wt. $\% \mathrm{NaCl}$. Salinity of the fluids in the primary fluid inclusions in the Salar Ignorado samples range from 1.6 to 27.4 eq. wt. \% $\mathrm{NaCl}$ (Appendix C).

One large gypsum crystal was subjected to detailed freezing-melting analysis along 28 sequential growth bands. The distribution of the $\mathrm{T}_{\mathrm{m} \text {, ice }}$ data was clustered into three distinctive hydrochemical signatures (Figure 12). At the base of the sample, primary FIAs 1 through 6 the $\mathrm{T}_{\mathrm{m} \text {, ice }}$ ranges from, $-3.1{ }^{\circ} \mathrm{C}(1.7$ eq. wt. $\% \mathrm{NaCl})$ to $-1.0{ }^{\circ} \mathrm{C}$ (5.1 eq. wt. $\% \mathrm{NaCl}$ ), with an average $\mathrm{T}_{\mathrm{m} \text {, ice }}$ of $-2.0{ }^{\circ} \mathrm{C}$ and an average $\mathrm{T}_{\text {eu }}$ of $-33.06{ }^{\circ} \mathrm{C}$. 

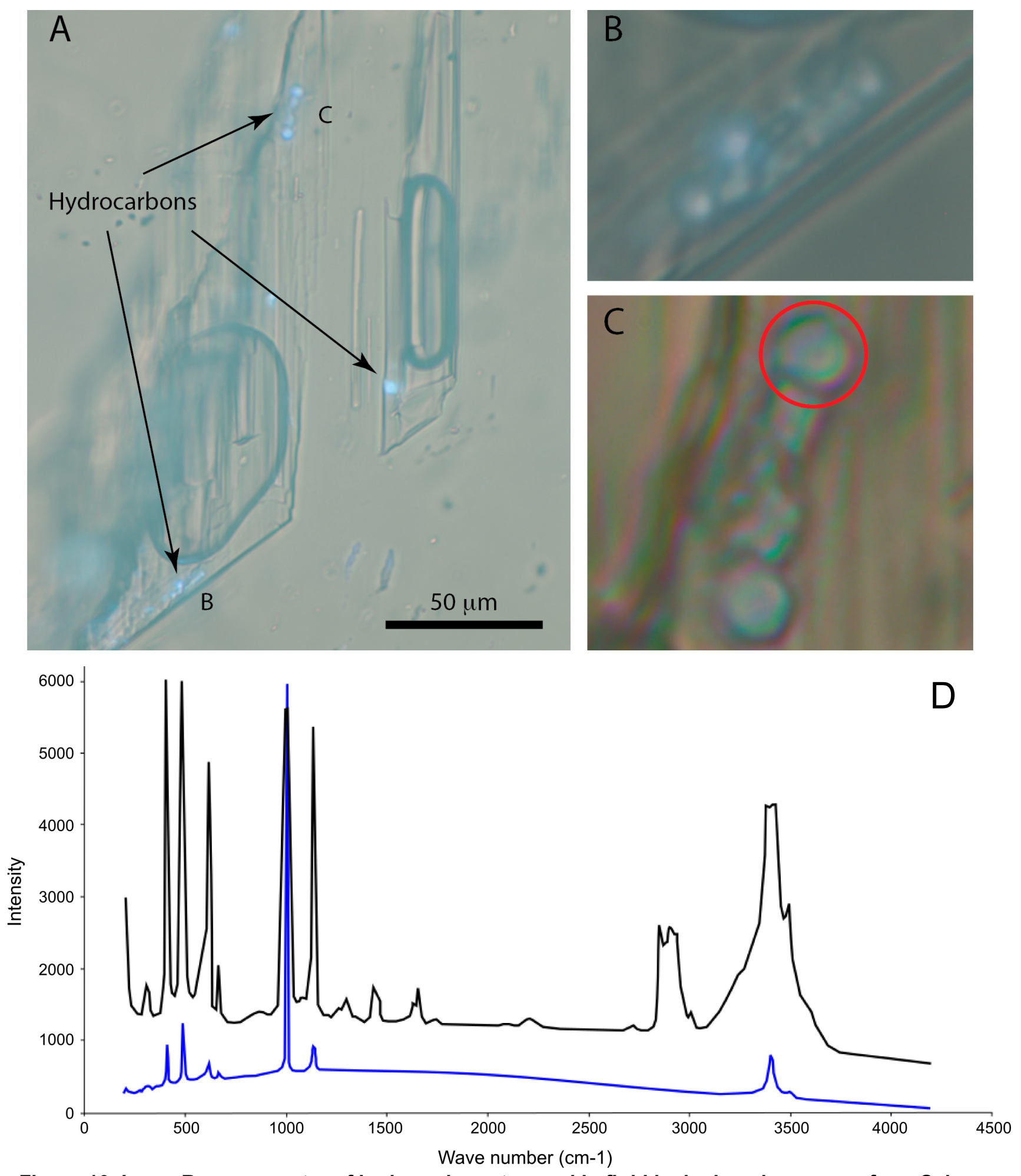

Figure 10. Laser Raman spectra of hydrocarbons trapped in fluid inclusions in gypsum from Salar Ignorado in hybrid plane polarized light and UV-vis. (A) Photo of Type I primary fluid inclusions containing high molecular weight, alkane-rich hydrocarbons. (B) Spherical hydrocarbons fluorescing blue from below the vapor bubble. (C) Lineament of spherical hydrocarbons, highlighted with the red circle corresponds to (D) the stacked laser Raman spectra of host gypsum (blue) and the spherical hydrocarbons (black). 
Karmanocky, F. J. III, 2014

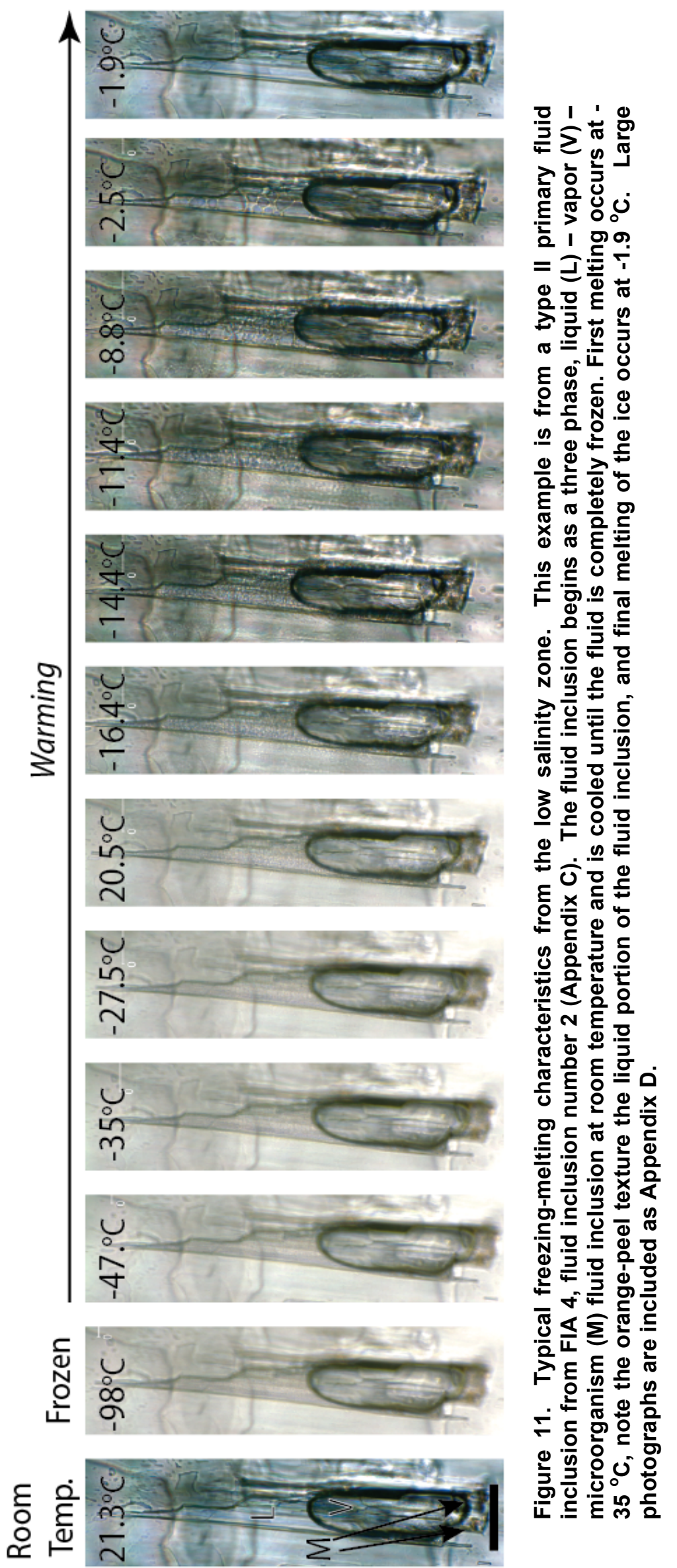



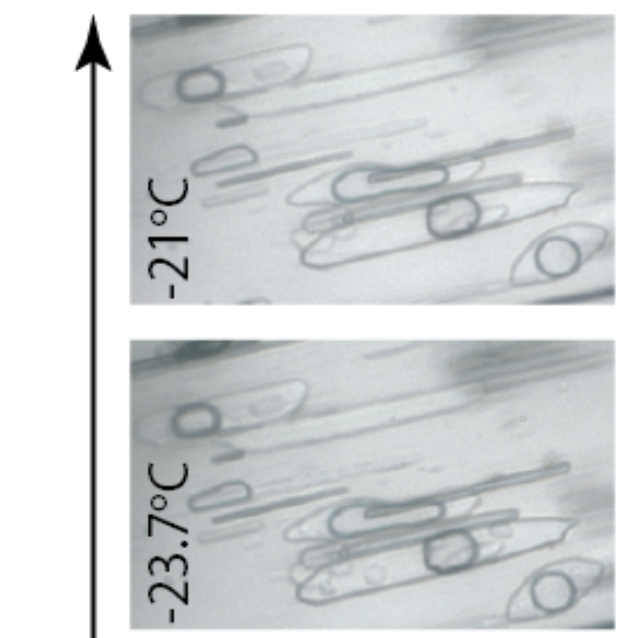

$\frac{\text { 을 }}{\frac{1}{\delta}}$
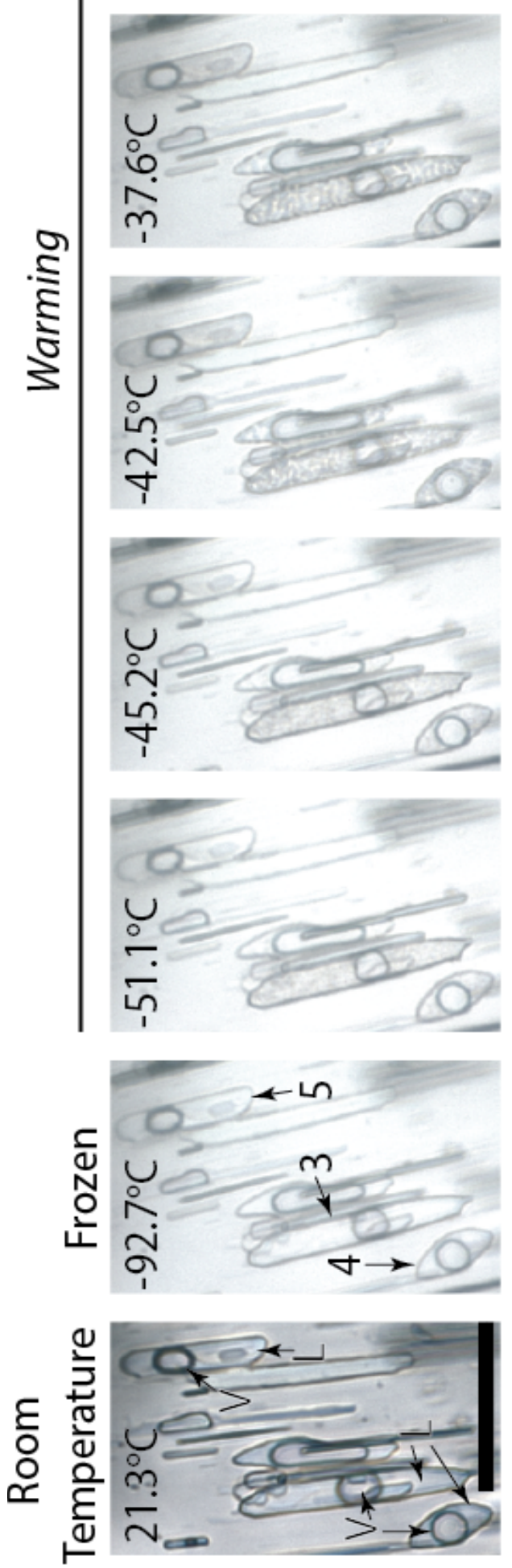

Karmanocky, F. J. III, 2014

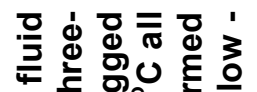

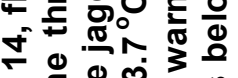

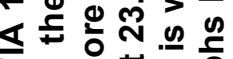
山ั

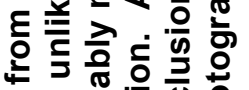
की

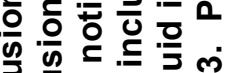

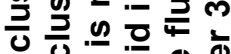
نَ

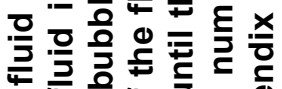

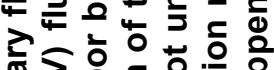
ส

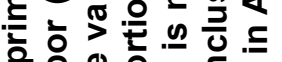
응 아응 응 융

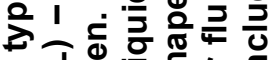
己造娄 인 은

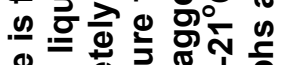
응 을 을 它

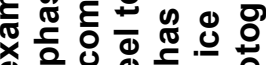

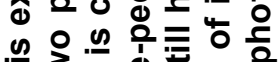
을 울 응

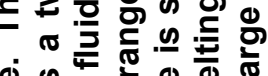
ฮ่

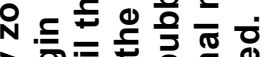

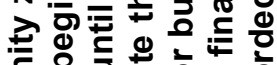

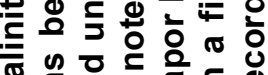

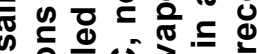

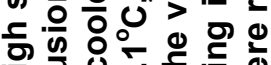
을 을 엉도 홓

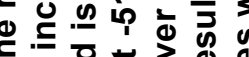

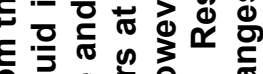
은 은 인 인

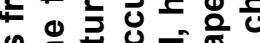

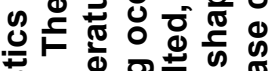

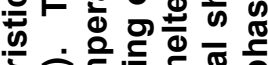
屯) 论

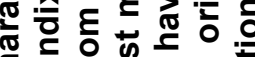
등은 은 은 흔

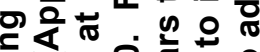

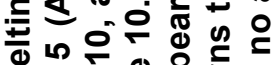
동 은 은 은 인

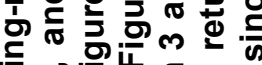

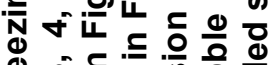
ఏ ธั丶万

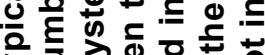

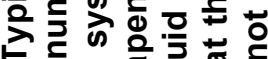

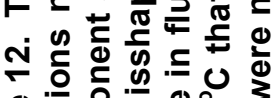

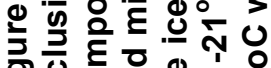


Karmanocky, F. J. III, 2014

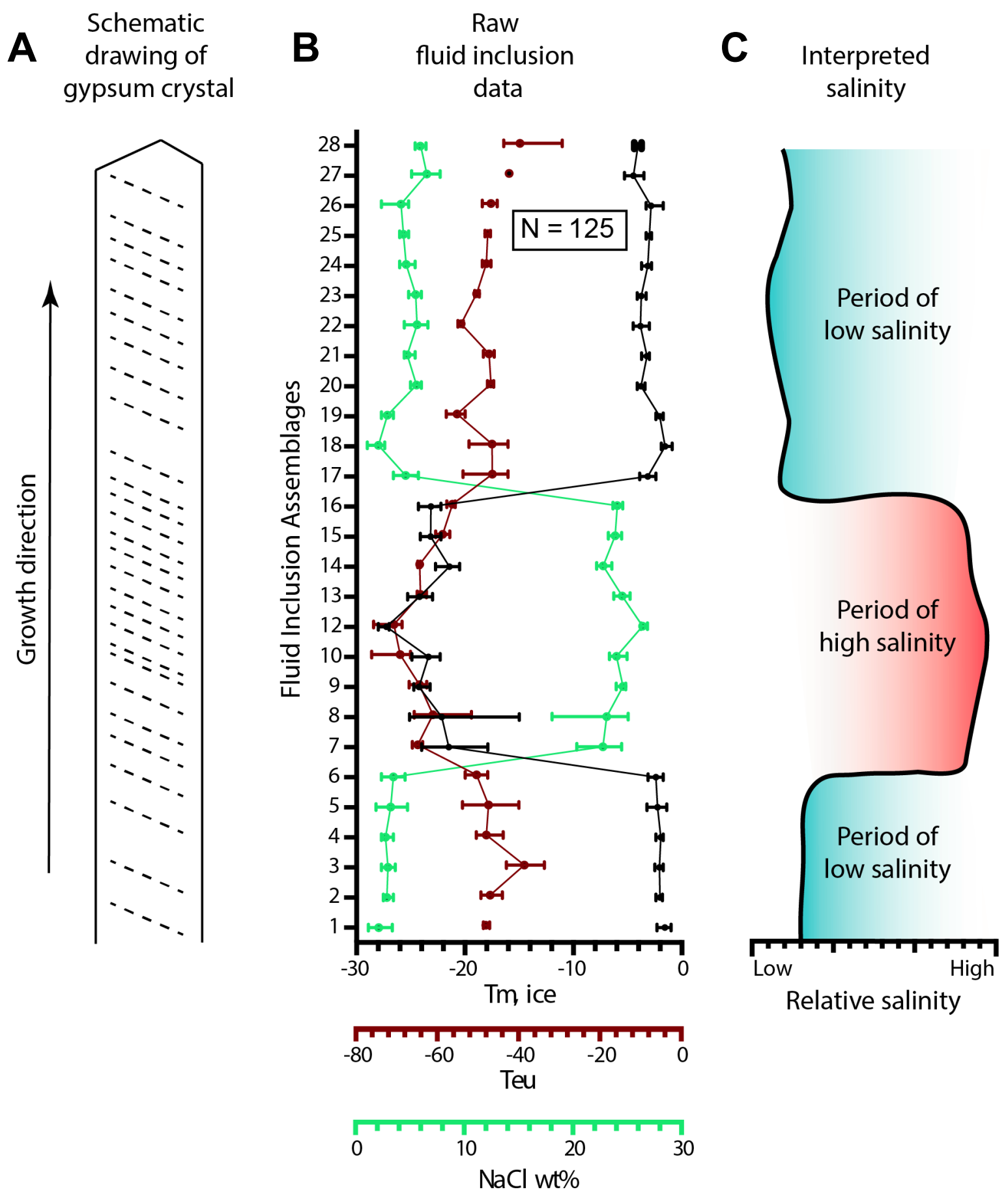

Figure 13. Summary of microthermometry data from one large gypsum crystal from Salar Ignorado. (A) Schematic of crystal showing, as dashed lines, the approximate locations of 28 growth bands composed of primary FIAs. Each numbered fluid inclusion asseblages on the left axis of (B) corresponds to FIAs shown as dashed lines in (A). The green line corresponds to the calculated eq. wt. \% $\mathrm{NaCl}$, red line is the measure eutectic temperature (Teu), and the black line is the final melting temperature of ice ( $\mathrm{Tm}$ or $\mathrm{Tm}$,ice). The data point ion the middle is the average for that FIA with minimum and maximum plotted. (C) The interpreted salinity trends from base to top of the crystal. 
Karmanocky, F. J. III, 2014

\section{DISCUSSION}

\section{Conditions that control the precipitation of gypsum}

Gypsum, halite, and native sulfur are the dominant evaporite minerals that precipitate from the pools at Salar Ignorado. Homogenizations runs to determine the minimum capture temperature of the fluid inclusions during entrapment were not successful. Heating of the gypsum resulted in desiccation at temperatures of $\sim 90{ }^{\circ} \mathrm{C}$. It is likely that the pool waters that precipitated the gypsum at Salar Ignorado were below the boiling point of water, since petrographic evidence of a boiling fluid was not identified. If fluid inclusions trapped boiling water, then they would contain a highly variable ratio of liquid to vapor, but that has not been observed. At the elevation of Salar Ignorado (4250 $\mathrm{m}$ asl) the atmosphere is much thinner as pressure is a function of elevation and is calculated to be between 0.59 and 0.61 atm (445.8 and 466.3 torr; Appendix G). The isothermal atmosphere equation was used and arranged as in Equation 2:

$$
\mathrm{P}_{\mathrm{h}}=\mathrm{P}_{0} \mathrm{e}^{-\mathrm{mgh} / \mathrm{RT}} \text {. }
$$

The temperature range observed during fieldwork $\left(-1\right.$ to $\left.24^{\circ} \mathrm{C}\right)$ corresponds to the range in the calculated barometric pressures above. A greater temperature variation is likely due to poorly recorded meteoric data for the region, thus a larger range of barometric pressures. Variations in barometric pressure $\left(\mathrm{p}^{*}\right)$ also affect the boiling point $\left(\mathrm{T}^{*}\right)$ of a fluid, which can be determined using the Clasius - Clapeyron equation (Equation 3). $\Delta_{\mathrm{vap}} \mathrm{H}$ is the enthalpy of vaporization and in the case of pure $\mathrm{H}_{2} \mathrm{O}$ is $40.68 \mathrm{~kJ} \mathrm{~mol}^{-1}$.

$$
\ln \left(\mathrm{p} / \mathrm{p}^{*}\right)=\Delta_{\mathrm{vap}} \mathrm{H} / \mathrm{R}\left[(1 / \mathrm{T})-\left(1 / \mathrm{T}^{*}\right)\right] .(3)
$$

The boiling point of a pure $\mathrm{H}_{2} \mathrm{O}$ fluid is calculated to be between 82.6 to $84.7{ }^{\circ} \mathrm{C}$. However the pool water at Salar Ignorado is not pure $\mathrm{H}_{2} \mathrm{O}$, rather an acidic saline solution 
of nonvolatile solutes including: $\mathrm{Na}, \mathrm{SO}_{4}, \mathrm{Mg}, \mathrm{Cl}, \mathrm{K}, \mathrm{Al}$, and $\mathrm{Ca}$ (Risacher et al., 2002).

With these constituents in solution, the boiling point would be expected to be slightly higher than calculated above with the Clasius - Clapeyron equation.

\section{Microorganisms and organic matter trapped in fluid inclusions}

Diverse microbiologic communities have been documented in volcanic lakes. Studies of the water in nearby crater lakes, like the summit lake from the Simba Volcano, have yielded many different types of microorganisms including: cyanobacteria, heterotrophic acidophilic bacteria, heterotrophic bacteria, acetogenic bacteria, methyltrophic bacteria (Demergasso et al., 2010). Other documented constituents in hydrothermal fluids of active volcanic settings include alkanes, alkenes, aromatics, and O-, S- and N-bearing compounds $\left(\mathrm{C}_{2}-\mathrm{C}_{20}\right.$ species; Tassi et al., 2010).

During times of increased hydrothermal activity organic compounds are transported to the surface where the hydrothermal fluid cools and condenses. Some of the cooled hydrothermal fluid can mix with the shallow aquifer and get transported to the surface. Once the fluid reaches the surface it collects in pools in depressions on the salar surface (Figure 14). The pool water may become saturated with respect to gypsum, which begins to precipitate. While the gypsum is precipitating organic compounds and volcanic gasses that are bubbling-up from the subsurface may be trapped along reentrants and kinks in the crystal surface. Microorganisms that are living in the pool water are also trapped in this way. Some microorganisms maybe trapped as a consequence of living on the surface of the gypsum or they may die and settle on the surface of the gypsum crystal. Volcanic gasses (e.g. $\mathrm{H}_{2} \mathrm{~S}, \mathrm{CH}_{4}$, and $\mathrm{CO}_{2}$ ), microorganisms, hydrocarbons, and particulates with the gypsum crystal are trapped as fluid inclusions. 


\section{Fluid inclusion petrography of gypsum: environmental implications}

The primary fluid inclusions in the gypsum precipitating from the acid saline pools at Salar Ignorado share similarities with primary fluid inclusions in gypsum studied by Sabaroud-Rosset (1969), Attia et al. (1994), Natalicchio et al. (2014), and Benison (2013). However there are some distinct differences in the shapes of the fluid inclusions from these studies and the current study on gypsum from Salar Ignorado. The fluid inclusions found in the Salar Ignorado gypsum tend to be wider at the base and taper upward to a point, forming a shape similar to an isosceles triangle. The edges of the primary fluid inclusions are typically serrated and in some cases the inclusions are amorphous (Figures 5, 7, 8, 9, and 10). Whereas fluid inclusions identified in the literature tend to have a very clear and well-defined base that is parallel to the growth face and strongly negative crystal shaped and in some cases sub-cubic, rectangular with rounded corners. Why does the Salar Ignorado gypsum display differences in primary fluid inclusion morphology? Might the variations in morphology act as environmental indicators of the conditions in which the gypsum precipitated? The sharp and sawtoothed shape of the fluid inclusion walls of the primary fluid inclusions from Salar Ignorado gypsum are potentially caused by rapid crystallization of the gypsum. Abundance of primary fluid inclusions in an assemblage have been documented and indicates rapid crystallization of the host crystal, however variations in the shape, though subtle, of the inclusions can also be important in interpreting the environmental evolution of a fluid from which the crystal formed. Little is known about the rate that gypsum can crystallize. The few published studies that exist give a large range from as little as 
$1.4 \pm 0.2 \times 10^{-7} \mathrm{~cm} / \mathrm{s}$ (Van Driessche et al., 2011) to less than $1 \mathrm{~cm}$ in millimeters in 17 to 24 weeks (Cody, 1976) and upwards of $1 \mathrm{~cm}$ per year (Schreiber and Hsu, 1980).

Salinity of the solution may also impact the shapes of the fluid inclusions. Cody (1976) grew gypsum crystals in smectite clays in a solution of $\mathrm{CaCl}_{2} \cdot \mathrm{H}_{2} \mathrm{O}$ and $\left(\mathrm{NH}_{4}\right)_{2} \mathrm{SO}_{4} \cdot \mathrm{H}_{2} \mathrm{O}$ and identified various gypsum crystal morphologies depending on the salinity of the solution. However, when the resulting crystals were photographed for publication, the fluid inclusions are not visible, and cannot be evaluated (e.g. Hardie, 1967). Others published scanning electron microscopy images of gypsum crystals, illustrating only surface features, not important internal features like fluid inclusions and growth zones (e.g. Buck and Hoesen, 2002; Mees et al., 2012; Kocherla, 2013). As the gypsum grows microscopic imperfections along the primary fluid inclusion walls will heal, and form a smoother walled inclusion similar to the inclusions documented in the literature (Sabaroud-Rosset, 1969; Attia et al., 1994; Natalicchio et al., 2014; Benison, 2013). This increased rate of gypsum growth inferred for the Salar Ignorado gypsum may be linked to increased magmatic and subsequent hydrothermal activity in the area. The salinity of the solution may not be the main factor, rather the saturation of the constituents required to form gypsum (Equation 4).

$$
\mathrm{Ca}^{2+}+\mathrm{SO}_{4}{ }^{2-}+2 \mathrm{H}_{2} \mathrm{O} \rightleftharpoons \mathrm{CaSO}_{4} \cdot \mathrm{H}_{2} \mathrm{O} \text {. (4) }
$$

Additionally, immiscible fluids from magmatic degassing can contribute $\mathrm{H}_{2} \mathrm{~S}, \mathrm{SO}_{2}$, and $\mathrm{CO}_{2}$ to the pool waters. These immiscible fluids can occupy atomic scale imperfections in the gypsum crystal. The immiscible fluid may retard the gypsum's ability to heal the jagged edges of the fluid inclusion. Of course, this would only be possible if the fluid inclusions contained an immiscible fluid. 
Karmanocky, F. J. III, 2014

\section{Possible fluid evolution models}

Trends in hydrochemistry occur at Salar Ignorado and are recorded by the fluid inclusions in gypsum actively precipitating from the salar pools. Three distinct hydrochemical trends have been identified in one large gypsum crystal (Figure 13). The lowest part of the crystal has fluid inclusions of low salinity (1.7 to 5.1 eq. wt. \% $\mathrm{NaCl}$ ), which abruptly transitions (between FIA 6 and 7) into high salinity in the middle of the crystal (18.6 and 25.5 eq. wt. \% NaCl), and abruptly transitions (between 16 and 17) back into a second low salinity at the top of the crystal (1.6 to 7.9 eq. wt. \% $\mathrm{NaCl}$ ). High salinity fluid inclusions in the middle of the crystal indicate that a sudden change in geochemical conditions occurred in the pool water at Salar Ignorado during the time that crystal grew. It is difficult to resolve what mechanism(s) maintain Salar Ignorado, and is beyond the scope of this master's thesis. However, three models are proposed below that may explain the genesis and perpetuation of the acid saline pool waters at Salar Ignorado.

\section{Model \#1: Hydrothermal source}

Salar Ignorado may be sourced only by the upwelling of hydrothermal fluid. There are times of high hydrothermal activity that result in higher salinity, gas and hydrocarbon rich pool waters. In contrast, during hydrothermal "quiet" times, pool waters are low salinity, and gas and hydrocarbon poor. Pool waters are constantly undergoing evapoconcentration, precipitating evaporite minerals. Rapid transition from low salinity pool waters to high salinity pool waters (see Figure 12) can be easily explained with a pulse of higher salinity hydrothermal fluid. On the other hand, this abrupt decrease in salinity between FIA 16 and 17 (see Figure 13) is more difficult to explain. Higher salinity fluids that were also rich in $\mathrm{H}_{2} \mathrm{~S}$ would precipitate both gypsum 
and native sulfur. Rapid precipitation of these minerals could lead to an abrupt decrease in salinity, marking a return to the hydrothermally "quiet" period.

\section{Model \#2: Meteoric influence}

Many saline waters have a meteoric origin. Water sourced as rain or snow can leach elements from rocks and sediments as a result of water-rock interactions. In a dry climate evapoconcentration occurs, concentrating the waters and causing precipitation of chemical sediments. Localized, rare rainstorms can increase water level, dissolve previously precipitated evaporites, and yield more saline waters. During droughts, desiccation can precipitate crusts of evaporite minerals. These types of floodingevapoconcentration-desiccation cycles have been well documented in some modern saline environments, such as Death Valley (Lowenstein and Hardie, 1985) and southern Western Australia (Benison et al., 2007).

\section{Model \#3: Mixed fluid source}

A combination of waters sourced from hydrothermal and meteoric origins could result in salars. Fluctuating water volumes and fluctuating water chemistry would be characteristic of a mixed fluid source. Hydrothermal fluids would contribute pulses of higher salinity waters, gasses and hydrocarbons. Meteoric water cycles would result in changing pool water volumes, as well as salinity changes.

\section{Model evaluation}

The most likely model of the hydrochemical processes and products of Salar Ignorado is based on Model \#3: Mixed fluid source (Figure 14) with significant hydrothermal inputs. During hydrothermally "quiet" times (FIAs 1 through 6) pool water 
at Salar Ignorado has relatively low salinity, whereas hydrothermally active times can be recorded as a pulse of increased salinity (FIAs 7 through 16). Increased magmatism results in the heating of water to temperatures of $\sim 200$ to $300^{\circ} \mathrm{C}$ and the generation of hydrothermal fluids. The hydrothermal fluid incorporates magmatic gasses such as $\mathrm{H}_{2} \mathrm{~S}$, $\mathrm{CO}_{2}, \mathrm{~N}, \mathrm{SO}, \mathrm{HCl}, \mathrm{H}_{2}, \mathrm{HF}, \mathrm{CO}, \mathrm{CH}_{4}$, and hydrocarbons. As the pulse hydrothermal fluids are transported to the surface, away from the magmatic heat source, they begin to cool and condense. Condensed hydrothermal fluids may be the main source of the shallow aquifer below Salar Ignorado, but it is also possible that some meteoric waters are cycled into the aquifer as well, even though meteoric precipitation is rare. Just below the salar surface minerals such as alunite, jarosite, hematite, and kaolinite precipitate from acid saline groundwater. In topographic lows, pools of cooled hydrothermal fluids collect and precipitate gypsum from $\mathrm{SO}_{4}-\mathrm{Al}-\mathrm{Cl}-\mathrm{Na}-\mathrm{K}$ rich water that contains lesser amounts of $\mathrm{Si}$ Mg-B. On topographic highs surrounding the pools, shallow groundwater is drawn to the surface precipitating fine crusts of gypsum, halite, and native sulfur.

Evidence of hydrothermal fluid can be seen in the fluid inclusions of the gypsum precipitating from Salar Ignorado pool water. The most important indication of the hydrothermal fluid is the abrupt, and sudden salinity change in the fluid inclusions from low salinity to high salinity. Other indications include high salinity primary fluid inclusions, and gasses, such as $\mathrm{H}_{2} \mathrm{~S}$, and hydrocarbons.

Hydrothermal fluids are typically considered to be high temperature. No evidence of elevated temperatures was documented in this study. However, if the fluid was hot enough to boil, then highly variable L:V ratios would exist in the primary fluid inclusions, but this is not the case, and should not be confused with the anomalous gas 
Karmanocky, F. J. III, 2014

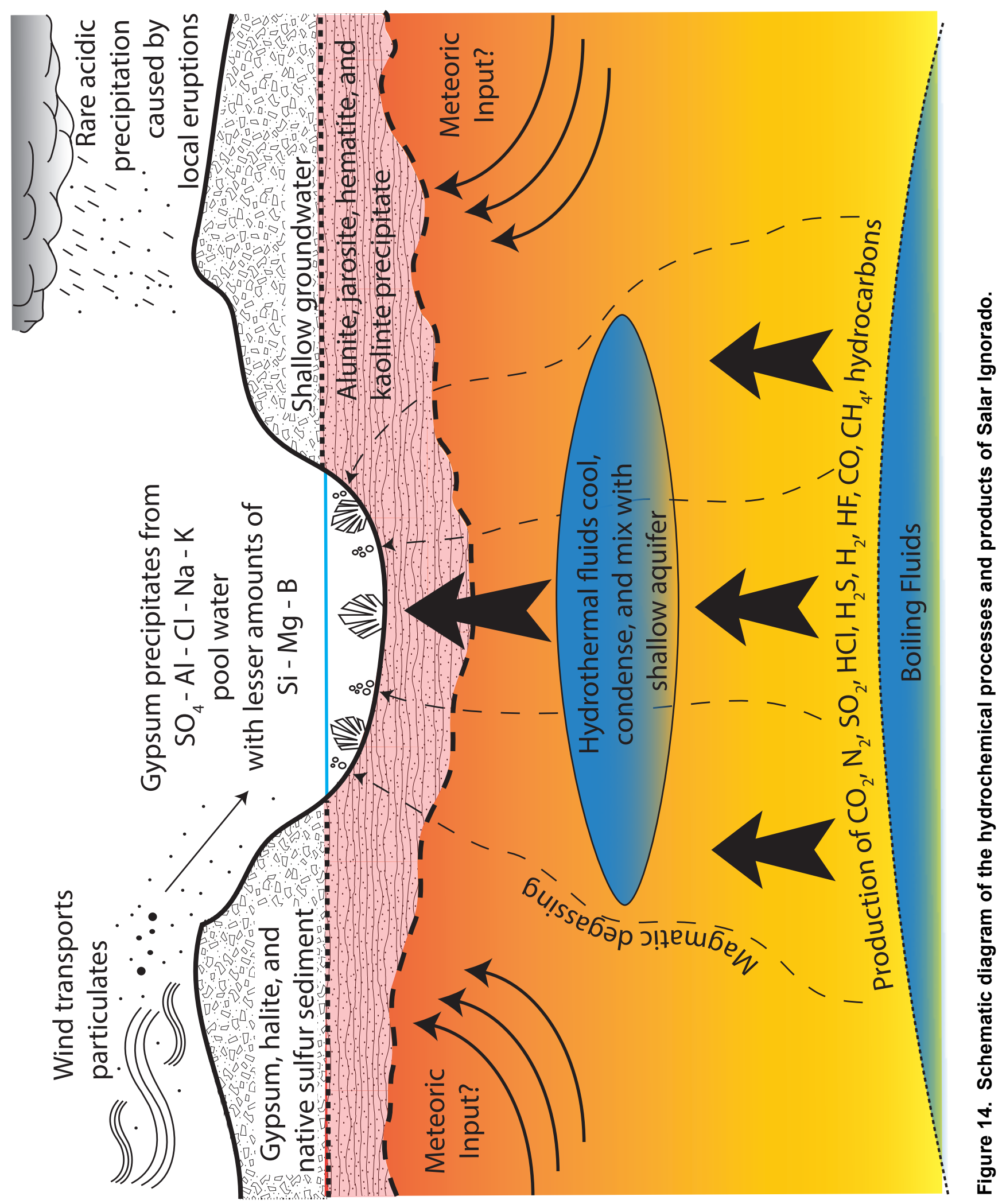


bubbles. Alternatively, if the fluid was not boiling, but was still elevated, temperatures above $\sim 50^{\circ} \mathrm{C}$, then primary fluid inclusions would generate a small vapor bubble and have similar L:V ratios. However, all liquid fluid inclusions in halite have been documented at $74^{\circ} \mathrm{C}$ (Zambito and Benison, 2013).

Some evidence of the three-presented models can be seen at Salar Ignorado. However, it is difficult to determine which would best explain the geochemical trends of the pool water recorded in the gypsum crystal. Salar Ignorado pool water is likely influenced by many factors including hydrothermal fluids and rare meteoric precipitation.

Meteoric precipitation as rain or snow has not been recorded at Salar Ignorado. There is no evidence of flooding-evapoconcentration-desiccation cycles at Salar Ignorado. In the field there is no indication that the pool waters have flooded the surface of the salar, rather the pool water levels remain relatively constant in spite of the high evaporation rates. Flooding of the salar would cause dissolution of the gypsum. However, there is no evidence of dissolution surfaces in the gypsum crystals; rather, petrography of gypsum indicates constant, uninterrupted growth. Also, there is no field evidence of intermittent streams or run-off from the elevated terrain surrounding Salar Ignorado either in the field or recorded in the gypsum.

\section{Other fluid evolution model considerations}

Trends in the microorganisms and hydrocarbons can also be indicators of environmental change. Microorganisms are sensitive to changes in the environment. If petrographic evidence supports an abrupt decrease or change in microorganism preentrapment, then a change in environmental conditions would be the culprit. If this was the case then there would likely be a correlation between the hydrochemistry and the 
number of microorganisms present in the fluid inclusions or as solid inclusions in the gypsum crystal. Identification of acidophilic or halophilic microorganisms would aid in determining the hydrochemistry. The $\mathrm{pH}$ in fluid inclusions in gypsum have not been determined in this study. If positive petrographic identification of acidophilic organisms was made in fluid inclusions of Salar Ignorado gypsum, then at least the habitable range of conditions for that microorganism could be considered.

Microorganisms have the potential to be trapped in fluid inclusions and as solid inclusions in gypsum (this study; Benison and Karmanocky, 2014), but whether gypsum demonstrates preferential entrapment of organisms has not been evaluated. On the other hand, if petrographic evidence supports post-entrapment death or the microorganism entering a survival mode, then it can be inferred that the microorganism was living on or near the surface of the gypsum crystal as the gypsum precipitated. In the large gypsum crystal evaluated from Salar Ignorado the distribution of microorganisms and hydrocarbons were not observed to follow distinct trends. Rather, different microorganism and hydrocarbons were found at various levels in the large gypsum crystal as both solid inclusions and fluid inclusions.

Meteoric fluids that interact with local volcanism can cause acid rain. However, volcanic ash was not observed interlayered with the gypsum crystals from Salar Ignorado. In active volcanic terrains, $\mathrm{H}_{2} \mathrm{O}$ can outgas and mix with constituents such as $\mathrm{SO}_{4}$ and generate acid water vapor. Once the water vapor cools and condenses it can be deposited on the salar surface.

It is important to consider the acidic nature of the precipitation, which plays a crucial role in stripping ions from the host volcanic rocks. It is possible that the lower 
acidity at Salar Ignorado plays a major role in perpetuating gypsum crystallization and not allowing significant accumulations of other evaporite minerals to form.

\section{CONCLUSIONS}

Although gypsum is a common and abundant sedimentary evaporite mineral, little research has been conducted on fluid inclusions in gypsum. This study contributes to a greater knowledge of the environments in which gypsum can form. The gypsum crystals that are actively precipitating from the acid saline Salar Ignorado contain abundant primary fluid inclusions that preserve evidence of past environmental conditions and trends in the evolution of the environment. Trends are evident in the geochemistry of the fluid inclusion assemblages as the gypsum crystals formed. This is the first time geochemical trends have been observed in gypsum from a modern active saltpan.

Salar Ignorado is intimately linked to the active Lastarria-Cordon del Azufre volcanic complex and the resulting hydrothermal system. The influence of the volcanic system has been recorded in the fluid inclusions as $\mathrm{H}_{2} \mathrm{~S}$ and spherical hydrocarbons linked to degassing. This indicates that the main source of the fluids is from a hydrothermal source, with minimal meteoric input. Salar Ignorado is sustained by episodic flows of hydrothermal waters to the near surface pools that deposit salts at the surface.

Of the three models proposed above it is most likely that Salar Ignorado is perpetuated by Model \#1: Hydrothermal source only. Circulation with the shallow aquifer, sourced by hydrothermal fluids would allow for consistent low salinity pool water. When magmatism peaks, resulting in increased hydrothermal activity, acidic saline water is injected into the system. Salinity in the pool water would increase until 
Karmanocky, F. J. III, 2014

the cycle would reach a state of low salinity, as the conditions were prior to the increased hydrothermal activity. 
Karmanocky, F. J. III, 2014

\title{
Chapter 3: Could microorganisms be preserved in Mars gypsum? Insights from terrestrial examples ${ }^{1}$
}

\begin{abstract}
Could the abundant sulfate salts on Mars contain microfossils and/or viable microorganisms? Here we report a variety of microorganisms trapped both as solid inclusions and as potentially viable halophilic and acidophilic prokaryotes and eukaryotes within fluid inclusions in Mars-analog gypsum. We have documented pennate diatoms, green algae, and prokaryotes in gypsum precipitated from acid $(\mathrm{pH} 1.8-4.6)$ saline $(5 \%-$ $28 \%$ total dissolved solids) waters at Salars Gorbea and Ignorado in an active volcanic terrain in the high Andes $(4000+\mathrm{m})$ of northern Chile. These salars are strikingly similar in geology and geochemistry to Mars. We propose that this discovery should serve as a model for fossilization of possible life on Mars and may inform methodologies used in future missions to Mars. Furthermore, the potential long term viability of microorganisms within fluid inclusions in gypsum suggests the possibility of a living, yet isolated and likely dormant, microbiological community on Mars today.
\end{abstract}

${ }^{1}$ Benison, K. C., Karmanocky, F. J. III, 2014, Could microorganisms be preserved in Mars gypsum? Insights from terrestrial examples, Geology, v. 42, no. 7, p. 615-618. 
Karmanocky, F. J. III, 2014

\section{INTRODUCTION}

Sulfate minerals, including an abundance of hydrated calcium sulfates such as gypsum, have been documented on the martian surface since the 1970s with data from satellites, landers, and rovers (i.e., Bell, 1996; Bishop et al., 2004; Clark and Van Hart, 1981; Clark et al., 2005; Gendrin et al., 2005). High-resolution cameras on rovers have detected various morphological forms of hydrated calcium sulfates (i.e., Grotzinger et al., 2005; Metz et al., 2009; Squyres et al., 2004). Interpretations include (1) gypsum sand and silt grains reworked by winds and shallow surface waters (e.g., Benison and Bowen, 2006; Grotzinger et al., 2005; Metz et al., 2009; Squyres et al., 2004), (2) molds after displacive gypsum (Benison and Bowen, 2006; Herkenhoff et al., 2004), and (3) veins of gypsum (Squyres et al., 2012). The hydrated calcium sulfates on Mars are widely considered to have originally grown by acid saline shallow surface waters and groundwaters (Benison and Bowen, 2006; Benison and LaClair, 2003; Squyres et al., 2004, 2012). Some martian groundwaters precipitated sulfates early, such as in the case of the displacive gypsum molds (Benison and Bowen, 2006); other groundwaters formed vein sulfates as a later diagenetic process (Squyres et al., 2012). Many of the sulfates were likely physically reworked by wind and/or water, resulting in some of the dunes and ripples in modern martian sand and silt, and ripple-marked and cross-bedded ancient martian siltstones and sandstones (Grotzinger et al., 2005; Metz et al., 2009).

Despite the abundance of gypsum on Mars and the search for signs of life on Mars, few studies have been conducted about the fossilization potential of gypsum on either Earth or Mars. The few published studies focus on the identification of modern microorganisms living on or near terrestrial gypsum (Vitek et al., 2013) or use destructive 
high-magnification methods that cannot constrain the origin or entrapment mode of the biological material within ancient crystals (Panieri et al., 2008; Schopf et al., 2012).

In contrast, studies of terrestrial halite $(\mathrm{NaCl})$, another common chemical sediment, have documented prokaryotic and eukaryotic microorganisms and organic compounds within primary fluid inclusions (Conner and Benison, 2013; Lowenstein, 2012; Norton and Grant, 1988; Schubert et al., 2010, 2009b). Combined optical, chemical, and biological methods have been refined for the study of biological materials within fluid inclusions in halite. Careful in-situ petrographic study, combined with geochronological constraints, has shown that microorganisms in primary fluid inclusions in various recent and ancient halite were trapped during crystal growth from surface water. Some of these entrapped microorganisms remain viable for at least tens of thousands of years (Schubert et al., 2009b; Mormile et al., 2003) and possibly for hundreds of millions of years (Vreeland et al., 2000, 2007). For this reason, evaporites may be considered to have exceptionally good fossilization potential. Although microorganisms have been documented in terrestrial halite and gypsum, the possibility of microorganisms in martian evaporites has been overlooked. For this reason, we must rely on Mars-analog evaporites to predict if martian evaporites might contain microorganisms.

Salars Gorbea and Ignorado are shallow acid saline lakes at $4000 \mathrm{~m}$ and $4200 \mathrm{~m}$, respectively, located in the high Andes of the Atacama region of northern Chile (Fig. 1A). These acid salars are located $\sim 200 \mathrm{~km}$ south of, and more than $1700 \mathrm{~m}$ higher in elevation than, the famous and larger Salar de Atacama. A survey of water geochemistry determined that of 84 Andean salars studied, only Salars Gorbea and Ignorado have low pH waters (Risacher et al., 2002). Surface waters and groundwaters at Salars Gorbea and 

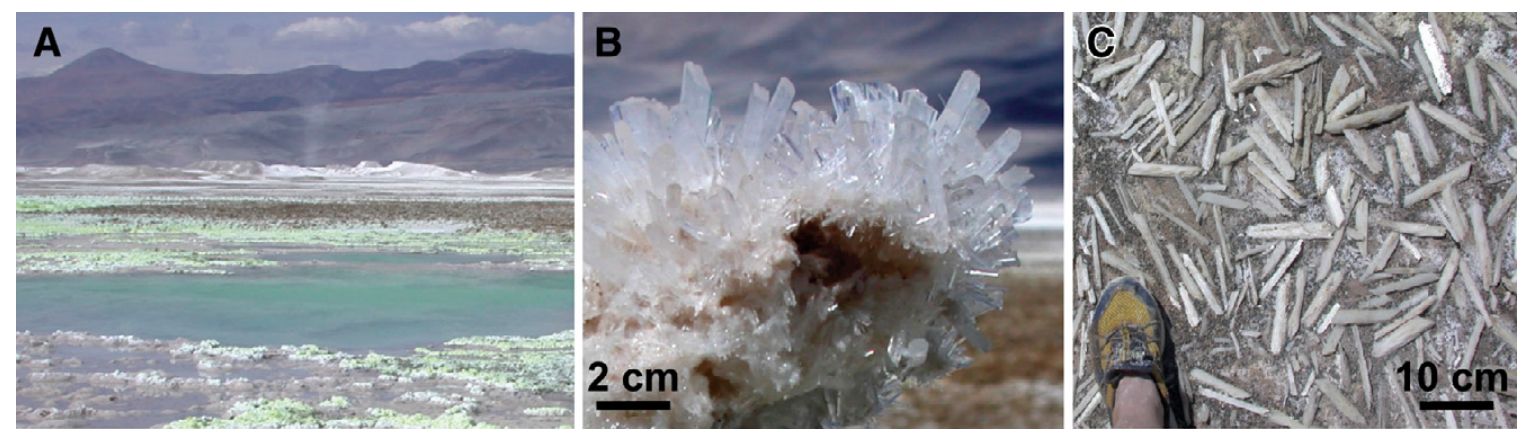

Figure 1. Gypsum at Salars Gorbea and Ignorado. A. View of Salar Gorbea showing acid saline pool with white gypsum and yellow sulfur in foreground, white gypsum dunes in middleground, and volcanoes in the background. B. Bottom-growth gypsum crystals, taken from acid saline surface water. C. Bedding plane with large eoliandeposited gypsum grains. Note foot for scale.

Ignorado are SO4-Na rich, with high amounts of $\mathrm{Mg}, \mathrm{Cl}, \mathrm{K}, \mathrm{Al}$, and $\mathrm{Ca}$ (Risacher et al., 2002). Preliminary microbiological analyses of surface waters at Salar Gorbea, focused on prokaryotes, identified several classes of bacteria, showing that microbial life exists in these acid saline waters (Escudero et al., 2013). The acid saline waters precipitate a suite of minerals besides gypsum, including halite, native sulfur, jarosite, alunite, hematite, and clay minerals (Benison and Gonzalez, 2007). The salars are hosted on the flanks of active composite volcanoes of the Cerro Bayo complex. The host sediment is volcanic sand and gravel of andesitic and dacitic composition.

Salars Gorbea and Ignorado are extreme terrestrial environments in several ways. The setting is high in elevation and extremely arid, with very high winds, large diurnal and seasonal temperature ranges, and little macroscopic life. Water chemistry is also extreme; the $\mathrm{pH}$ is as low as 1.8 and salinity is as high as $28 \%$ total dissolved solids (Benison and Gonzalez, 2007). We propose that Salars Gorbea and Ignorado are among the best-known terrestrial analogs for Mars because they are similar in geochemistry, mineral composition, and sedimentary processes and products. 
Karmanocky, F. J. III, 2014

\section{MATERIALS AND METHODS}

Fieldwork was conducted in March 2007 and consisted of documenting geological and geochemical characteristics and collecting samples. Sedimentary facies were mapped, with careful attention paid to observations of physical, chemical, and biological processes and the resulting products. Field geochemistry included measurements of surface water and groundwater depths, temperatures, $\mathrm{pH}$, and total dissolved salinity. Mineral, sediment, rock, and water samples were collected.

Gypsum crystals were prepared minimally; by cleaving with a clean razor blade to obtain a thickness of 1-2 mm. Splitting crystals along cleavage planes resulted in smooth surfaces and made polishing unnecessary. Observations were made first with an Olympus SZX10 transmitted light stereo microscope, at magnification range of 6.3-63x, allowing for fluid inclusion assemblages to be determined. Higher magnification observations were made with an Olympus BX52 research petrographic microscope with transmitted, reflected, polarized, and ultraviolet visible (UV-vis; excitation by combined $330 \mathrm{~nm} \mathrm{UV}$ and $385 \mathrm{~nm}$ visible) light sources. The color of fluorescence relates to the type of organic matter (Mormile and Storrie-Lombardi, 2005; see Supplemental Information). With the wavelengths of combined UV and visible light used for this study, prokaryotes fluoresced pale green, algae fluoresced blue, and carotenoids fluoresced red, orange, and pink (Conner and Benison, 2013). Magnification to 2000x into the gypsum crystal interior was conducted via long working distance objectives. Both microscopes are equipped with digital cameras and Spot Imaging Solution 5.0 software. 
Karmanocky, F. J. III, 2014

\section{RESULTS}

\section{Gypsum Sedimentology}

We have identified four types of gypsum at Salars Gorbea and Ignorado. Centimeter-scale, bottom-growth bladed gypsum crystals were observed growing in subaqueous clusters in shallow (up to $2 \mathrm{~m}$ deep) surface-water pools (Fig. 1B). Abraded, randomly oriented bladed gypsum crystals found in dunes and on sub-aerially exposed surfaces, as well as unconsolidated in some surface pools, are interpreted as having originated as bottom-growth crystals and then reworked by strong winds as sand and gravel grains (Fig. 1C). Tiny (millimeter-scale) needle-like gypsum crystals were found in subaerial crusts with native sulfur and tiny crystals of halite and other sulfate minerals. These efflorescent crusts formed as acid saline groundwater wicked to the surface by evaporation and underwent rapid precipitation (Smoot and Castens-Seidell, 1994). The

fourth type of gypsum noted at Salars Gorbea and Ignorado was displacive lath-shaped crystals in the shallow subsurface sediments. For this study, we focus on the first two types of gypsum: the bottom-growth crystals (Fig. 1B) and the reworked grains (Fig. 1C). Both originated by precipitation from shallow surface waters and both contain abundant and large primary fluid inclusions that are remnants of these shallow surface waters.

\section{Fluid Inclusion Petrography}

Primary fluid inclusions are abundant and relatively large in gypsum from Salars Gorbea and Ignorado. They are as long as $100 \mu \mathrm{m}$ and contain all-liquid, liquid-gas, liquid-solid, or liquid-gas-solid. Primary fluid inclusion assemblages, aligned in planes parallel to crystal faces, are interpreted to have formed from parent surface waters. Bottom-growth gypsum crystals host primary fluid inclusions, which represent modern 
acid saline pool fluids. Similar primary fluid inclusions in eolian transported gypsum grains originated as bottom-growth crystals before they were reworked by wind (Benison and Gonzalez, 2007), so they also represent surface acid saline fluids.

\section{Microorganisms in Gypsum}

Pennate diatoms exist as solid inclusions and within primary fluid inclusions (Figs. $2 \mathrm{~A}$ and $2 \mathrm{~B}$ ). Due to their relatively large size, $\sim 30 \mu \mathrm{m}$, they are readily recognized. They appear to represent one species, based on consistent morphology and size. Some clusters of dozens of diatoms appear pristine, suggesting that they had been living in the salar pool immediately before being trapped as the gypsum crystal grew (Fig. 2A). Other clusters contain abundant broken diatoms, indicating that they were abraded during wind transport and were physically deposited into the salar pool before being trapped in the growing gypsum (Fig. 2B). Diatoms entrapped within fluid inclusions are relatively rare. We have observed as many as three diatoms within an individual fluid inclusion. Like the solid inclusions of diatoms, some of the diatoms in fluid inclusions are pristine and some are abraded. Discrete parts of pristine diatoms fluoresce blue when exposed to UV-vis light (Fig. 2A2). Suspect green algae are relatively abundant in Salar Gorbea and Ignorado gypsum. They appear as pale yellow and pale orange dimpled spheres and ovoids ranging in size from $\sim 3 \mu \mathrm{m}$ to $10 \mu \mathrm{m}$ and are observed both as solid inclusions and in fluid inclusions (Figs. 2B, 2C, 2E, and 2H). They fluoresce blue (Fig. 2E). Some have a collapsed appearance, suggesting response to environmental stress (osmotic) and subsequent dormancy in a cyst state. Multiple spheres and ovoids are typically found together, with as many as $\sim 20$ in some individual inclusions. Many are quite similar in appearance to Dunaliella algae (Fig. 2D), documented in fluid inclusions in halite from 
ephemeral saline lakes elsewhere in the world, including in neutral Death Valley and Saline Valley in California (Lowenstein, 2012; Schubert et al., 2010) and acid Lake Magic in Western Australia (Conner and Benison, 2013).

Suspect algae are typically accompanied by a clear, gel-like envelope (Fig. 2E), a red mass (Fig. 2C), or orange crystals. The clear envelope, red masses, and orange crystals fluoresce pale pink-orange, suggesting an organic compound such as glycerol and/or beta-carotene, both of which are commonly associated with halophilic algae (Schubert et al., 2010; Conner and Benison, 2013).

Prokaryotes are observed both as solid inclusions and within some fluid inclusions in gypsum (Fig. 2G). They appear as clear to pale yellow, high-relief, 1-2- $\mu \mathrm{m}-$
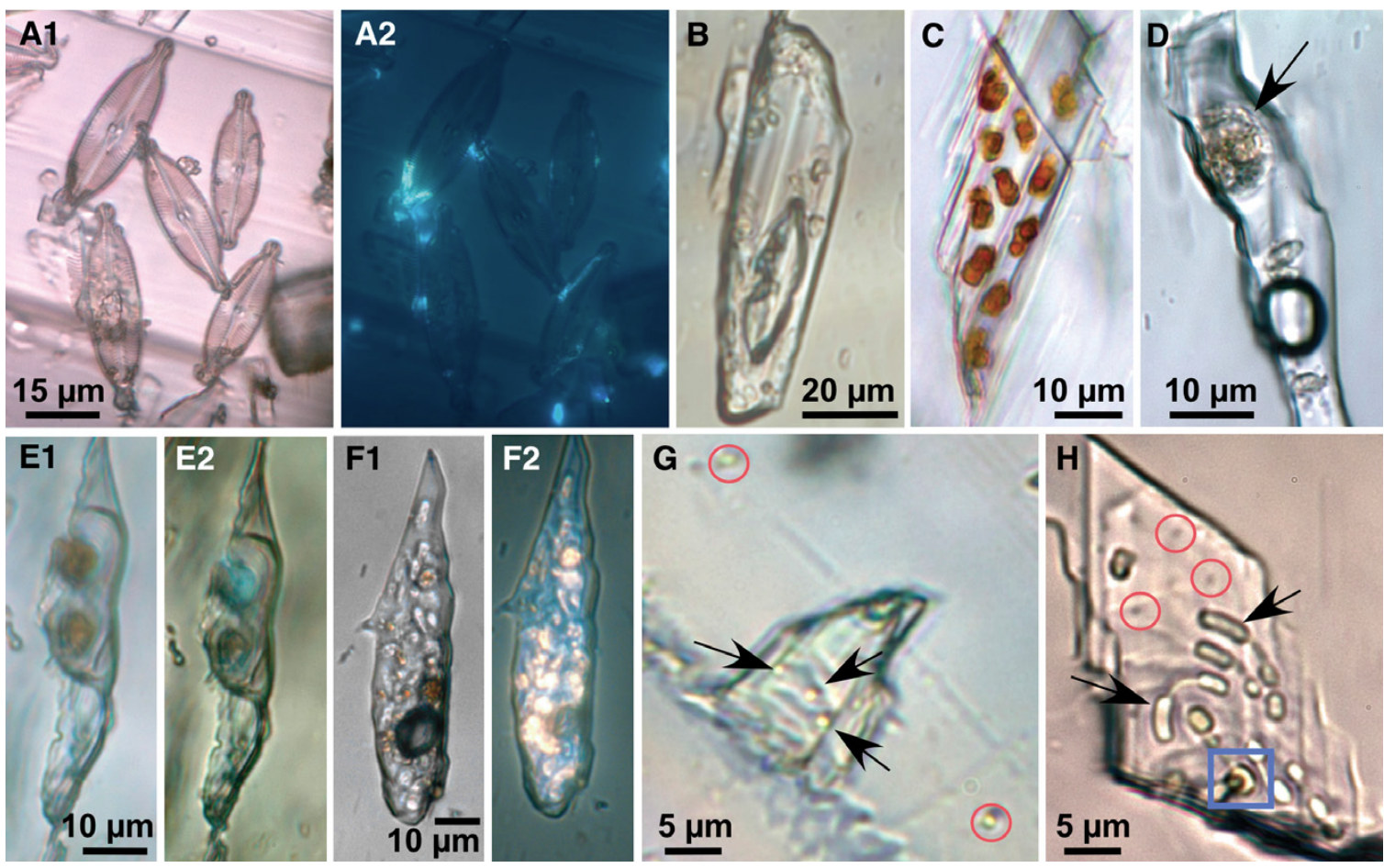

Figure 2. Microorganisms in Salars Gorbea and Ignorado gypsum. A. Pennate diatoms in solid gypsum. B. Abraded pennate diatom in fluid inclusion, along with algal cells and prokaryotes. C. Cocci (arrow) in fluid inclusion. D. Algae (pale orange) and suspect beta-carotene (dark orange) in fluid inclusion. E. Two algal cells surrounded by clear gel in fluid inclusion, transmitted light (E1) and UV-vis light (E2). F. Prokaryotes and algae in fluid inclusion, transmitted light (F1) and UV-vis light (F2). G. Suspect Dunaliella algae (arrow) in fluid inclusion. (E2). H. Fluid inclusion containing moving prokaryotes (red circles) and pale yellow algae. 


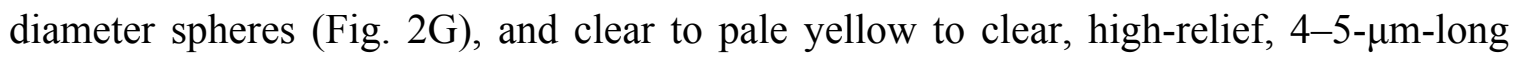
rods (Fig. 2H). All fluoresce pale green when exposed to UV-vis light. Some of these coccoid and bacilli-shaped cells appeared to move within the fluid inclusions, likely due to Brownian motion. These characteristics are consistent with prokaryotes (Conner and Benison, 2013; Lowenstein, 2012; Mormile and Storrie-Lombardi, 2005; Schubert et al., 2009a, 2009b, 2010). We interpret them as bacteria and/or Archea.

\section{DISCUSSION}

Fluid inclusions may serve as host microenvironments for microorganisms. Previous workers have extracted inclusion fluids from halite and successfully cultured microorganisms, showing the viability of some microorganisms trapped within fluid inclusions (e.g., Lowenstein, 2012; Mormile et al., 2003). The optical methods we employ should be considered only a first step to guide further studies that may lead to chemical and DNA identification. In addition, the in-situ and nondestructive nature of the optical observations eliminates concerns about possible contamination.

Could microfossils and/or viable microorganisms be trapped in gypsum on Mars as they are in gypsum on Earth? It is likely that abundant sulfate sand grains on Mars contain fluid inclusions similar to those in the acid-precipitated bottom-growth and reworked gypsum we discuss here. We suggest that gypsum on Mars would have entrapped, as solid inclusions and within fluid inclusions, any microorganisms and/or organic compounds that were present in its parent waters. Therefore, fluid inclusions and solid inclusions hosted by salt minerals may be the best place to continue the search for life on Mars. 
We propose that future lander and rover missions to Mars should be equipped with cleaving and optical imaging capabilities with magnification up to $2000 \times$. These tools would allow for martian gypsum and other salt minerals to be optically examined in situ for microfossils. This optical examination might provide preliminary evidence of life and would be useful in targeting specific samples for more advanced methods, such as laser Raman spectroscopy, which would lead to chemical and biological identification of organic materials.

Recent studies have suggested that Mars has, at times, been habitable (i.e., Squyres et al., 2012). However, the recognition of some microenvironments, such as fluid inclusions in halite and gypsum, has been overlooked. Our sedimentological and petrographic observations of gypsum from a Mars-analog setting demonstrate the remarkable ability of these minerals to trap and preserve microbiological communities. This leaves open the possibility that there may be a living microbiological community on Mars today.

\section{ACKNOWLEDGMENTS}

We thank Maria Mercedes Gonzalez, Diane Goulder, and Jorge Lempe Vorpahl for field assistance, and Reed Wicander for initial consultation on diatoms. Bonnie Baxter, B. Charlotte Schreiber, an anonymous reviewer, and editor Ronadh Cox are thanked for their constructive reviews. A National Geographic Society Research and Exploration Grant to Benison funded fieldwork. Samples are stored at the Department of Geology and Geography at West Virginia University, Morgantown, West Virginia, USA. 
Karmanocky, F. J. III, 2014

\section{Chapter 4: Conclusions and Recommendations}

\section{CONCLUSIONS}

Fluid inclusions in gypsum have a bright future. Though many workers have not utilized them to their potential it is possible that they can be used more often in studies where other minerals are not present. Even though there are some reservations with regards to the viability of the fluid inclusions in gypsum, simple petrography can alleviate those concerns. This study will contribute a greater knowledge of the environments from which gypsum can form. The gypsum crystals that are actively precipitating from the acid saline Salar Ignorado contain abundant primary fluid inclusions that preserve past environmental conditions and trends of the evolution of the environment. Trends are evident in the geochemistry of the fluid inclusion assemblages as individual gypsum crystals formed. This is the first time geochemical trends have been observed in gypsum from a modern active saltpan. Salar Ignorado is intimately linked to the active LastarriaCordon del Azufre volcanic complex and resulting hydrothermal system. The influence of the volcanic system has been recorded in the fluid inclusions as $\mathrm{H}_{2} \mathrm{~S}$ and spherical hydrocarbons linked to degassing.

\section{RECOMMENDATIONS}

This study accomplished many of the goals put forth at the time of the thesis proposal as well as some additional goals that were identified du ring the research. There are also some instances where the time allotted was not sufficient to effectively complete an experiment or set of experiments to achieve a particular goal. This section serves as a list and description of the future work that can be completed to help answer some of the 
standing questions posed by the research and some that the author could not complete in a timely manner.

\section{Gypsum growth rates}

As noted multiple times in the text, we do not know how long it takes for gypsum crystals to nucleate from a saturated solution and grow. There are many acting forces on the gypsum growth system. The environmental conditions such as $\mathrm{pH}$, salinity, temperature, evaporation, water source, availability of water, ions in solution, and seeding material, all contribute to the rate of gypsum growth.

A study could be undertaken to grow gypsum in the lab under various conditions that mimic environmental conditions that modern gypsum forms in and compare the results. Listed in the following sections are very general steps that could be taken to understand gypsum growth rates from the spectrum of gypsum deposits around the world.

Step One: Sample collection

The researcher would need to have an understanding of how various types of gypsum look petrographically. Samples could be collected from very different locations, including: (1) Volcanic acid saline pools at Salar Ignorado and Salar Gorbea, (2) continental acid brines from Western Australia, (3) sahbkas in the Mediterranean and Shark Bay, and (4) continental deposits like Tuz Golu in Turkey or Death Valley. Petrographic characteristics such as solid and fluid inclusions should be documented, and overall shape of the gypsum crystals. This information should be indicative of environmental conditions as demonstrated for Salar Ignorado in this study. 


\section{Step Two: Growing samples in the lab}

Solutions that mimic the conditions that the field samples were collected from should be used in order to validate that the conditions that lab crystals grew in were analogous to the field conditions. The issue with this facet of the experiment is how to generate or nucleate gypsum crystals. The methodology of Cody (1976) included the use of smectite clay as the nucleating surface for gypsum. This was done since most of the samples or environments that Cody (1976) was interested in had lake bottoms of similar mineralogy. However that is not the case with all gypsum deposits. An appropriate medium should be identified for each sample.

\section{Step Three: Petrography of laboratory grown gypsum crystals}

Evaluation of the laboratory grown gypsum crystals would be final step in the workflow. Once the gypsum has grown to a size that is possible to work with, the researcher can evaluate the shapes of the crystals and their inclusions. Solid and fluid inclusions should be documented to help understand how the crystal grew. Since the amount of time it took the crystal to grow is known, the fluid inclusion assemblages (if present) could be tied to the amount of time it takes a gypsum crystal to grow under the accompanying environmental conditions.

\section{Summary}

It is difficult to pin point the exact growth rates of gypsum but it can be quite slow, so a master's project may not be a sufficient amount of time to conduct such as experiment. Understanding gypsum growth may be better suited as an ancillary project for a $\mathrm{PhD}$ student in the future. However a second option would be to break up the samples into various localities. Have a few different master's projects. A group to work 
on the petrography of various types of gypsum, a second generation of students to collect geochemical data of the fluids, a third generation of students to grow samples in the lab, and finally the advisor with the help of a PhD student to put the whole picture together.

\section{Mechanisms that control gypsum growth}

An experiment that could be undertaken could be related to "step two" of the "gypsum growth rates" project. A student could work with different nucleating or seeding media, sample container size and shape, and other aspects to accurately simulate the natural environment that gypsum forms. It would be beneficial at this stage to keep the fluid and other conditions the same, a supersaturated solution at standard temperature and pressure.

It would be interesting to add microorganisms to the solution and look at how they can affect the gypsum growth. A survey of halophilic and acidophilic extremophiles in lakes that precipitate gypsum could be performed, similar to work done by Lowenstein (2012) and cultures of those microorganisms could be added to the solution and monitored. 
Karmanocky, F. J. III, 2014

\section{REFERENCES CITED}

Aguilera, F., Tassi, F., Darrah, T., Moune, S., Vaselli, O., 2012, Geochemical model of a magmatic - hydrothermal system at the Lastarria volcano, northern Chile: Bulletin of Volcanology, v. 74, p. 119-134.

Alonso, R. N., Jordan, T.E., Tabbutt, K. T., Vandervoort, D. S., 1991, Giant evaporite belts of the Neogen central Andes: Geology, v. 19, no. 4, p. 401-404.

Attia, O.E., Lowenstein, T.K., Wali, A., 1995, Middle Miocene gypsum, Gulf of Suez: marine or nonmarine: Journal of Sedimentary Research, v. A65, no. 4, p. 614-626.

Bell, J.F., III, 1996, Iron, sulfate, carbonate, and hydrated minerals on Mars, in Dyar, M.D., McCammon, C., and Schaefer, M., eds., Mineral Spectroscopy: A Tribute to Roger G. Burns, Geochemical Society Special Publication 5, p. 359-380.

Benison, K.C. and Bowen, B.B., 2006, Acid saline lake systems give clues about past environments and the search for life on Mars: Icarus, v. 183, p. 225-229.

Benison, K.C., 2007, unpublished field notes: Salars Gorbea and Ignorado.

Benison, K.C., 2013, Acid saline fluid inclusions: Examples from modern and Permian lake systems: Geofluids, v. 13, p. 579-593.

Benison, K.C., Bowen, B.B., Foster, R.M., Jagniecki, E.A., LaClair, D.A., Walker, J., Gonzalez, M.M., Sirbescu, M.C., Student, J.J., Story, S.L., Oboh-Ikuenobe, F.E., Hong, B.Y., Mormile, M.R., Storrie-Lombardi, M., and Johnson, S.S., 2007a, Field observations and lab tests of acid brines: Implications for past deposition, diagenesis, and life on Mars: Seventh International Conference on Mars, Pasadena, CA, abstract 3175 . 
Benison, K.C., Bowen, B.B., Oboh-Ikuenobe, F.E, Jagniecki, E.A., LaClair, D.A., Story, S.L., Mormile, M.R., and Hong, B.Y., 2007b, Sedimentology of acid saline lakes in southern Western Australia: Newly described processes and products of an extreme environment: Journal of Sedimentary Research, v. 77, p. 366-388.

Benison, K.C., Gonzalez, M.M., 2007, Sedimentology of two acid saline lakes in the high Andes of northern Chile: Geological Society of America Abstracts with Programs, v. 39, no. 6, p. 433.

Benison, K.C., LaClair, D.A., 2003, Modern and ancient extremely acid saline deposits: terrestrial analogues for Martian environments?: Astrobiology, v. 3, no. 3, p. 609618.

Bishop, J.L., Dyar, M.D., Lane, M.D., and Banfield, J.F., 2005, Spectral identification of hydrated sulfates on Mars and comparison with acidic environments on Earth: International Journal of Astrobiology, v. 3, p. 275-285.

Bodnar, R.J., 1992, Revised equation and table for freezing point depressions of $\mathrm{H}_{2} \mathrm{O}$-salt fluid inclusions (abstract): PACROFI IV, Fourth Bennial Pan-American Conference on Research on Fluid Inclusions, Program and Abstracts, Lake Arrowhead, CA, v. 4, p. 108-111.

Buck, B. J., Hoesen, J. G., 2002, Snaowball morphology and SEM analysis of pedogenic gypsum, southern New Mexico, U.S.A.: Journal of Arid Environments, v. 51, p. $469-487$.

Burruss, R.C., 2003, Petroleum fluid inclusions, an introduction In Samson, I.M., Anderson, A.J., Marshall, D.D., eds., Fluid Inclusions: Analysis and 
Interpretation, Mineralogical Association of Canada, Short Course Series, v. 32, p. $159-174$.

Clark, B.C. and Van Hart, D.C., 1981, The salts of Mars: Icarus, v. 45, p, 370-378.

Clark, B.C. and 23 others, 2005, Chemistry and mineralogy of outcrops at Meridiani Planum: Earth and Planetary Science Letters, v. 240, p. 73-94.

Conner, A., Benison, K.C., 2013, Acidophilic halophilic microorganisms in fluid inclusions in halite from Lake Magic, Western Australia: Astrobiology, v. 9, p. $850-860$.

Cornejo, P., 1987, Hydrothermal alteration zones and sulfur deposits in Upper Cenozoic volcanoes of Salar de Gorbea, Andes of Northern Chile: Pacific Rim Congress, v.87, p. $877-885$.

Davis, D.W., Lowenstein, T.K., Spencer, R.J., 1990, Melting behavior of fluid inclusions in laboratory-grown halite crystals in systems $\mathrm{NaCl}-\mathrm{H}_{2} \mathrm{O}, \mathrm{NaCl}-\mathrm{KCl}-\mathrm{H}_{2} \mathrm{O}, \mathrm{NaCl}-$ $\mathrm{MgCl}_{2}-\mathrm{H}_{2} \mathrm{O}$, and $\mathrm{NaCl}-\mathrm{CaCl}_{2}-\mathrm{H}_{2} \mathrm{O}$ : Geochemica et Cosomochimica Acta, v. 54, p. 591-601.

Deer, W.A., Howie, R.A., Zussman, J., 1992, An introduction to the rock-forming minerals, $2^{\text {nd }}$ ed.: London, England, Prentice Hall, 696 p.

Drever, J. I., 1988, The Geochemistry of Natural Waters: Edgewood Cliffs, New Jersey, Prentice Hall, 437 p.

Ericksen, G.E., Chong, G. and Vila, T., 1976, Lithium resources of Salars in the central Andes. In Lithium Resources and Requirements by the Year 2000, eds. Vine, J.D., US Geol. Survey Prof. Paper, 1005, p. 66-74. 
Ericksen, G.E., Vine, J.D. and Ballon, A.R., 1977, Chemical composition and distribution of lithium-rich brines in Salar de Uyuni and nearby salars in southwestern Bolivia: Energy, v. 3, p. 355-363.

Escudero, L.V., Bijman, J., Chong, G., Pueyo, J.J., and Demergasso, C., 2013, Geochemistry and microbiology in an acidic, high altitude $(4,000 \mathrm{~m})$ salt flat, high Andes, northern Chile. Advanced Materials Research, v. 825, p. 28-32.

Eugster, H.P., Jones, B.F., 1979, Behavior of solutes during closed basin brine evolution: American Journal of Science, v. 279, p. 609-31.

Eugster, H.P., 1984, Geochemistry and sedimentology of marine and non marine evaporites: Ecol. Geol. Helv., 77, 237-248.

Ferraris, F., Vila, T., 1990, Volcanic sulfur deposits in the Andes of northern Chile, in footnote, L., Amstutz, G., Cardozo, M., Cedilo, E., Frutos, J., eds., Stratabound Ore Deposits in the Andes: Special Publication of the Society for Geology Applied to Mineral Deposits No. 8, p. 691-701.

Garret, D.E., 2001, Sodium sulfate: handbook of deposits, processing, properties, and uses, Elsivier, Amsterdam, 384 p.

Garcia-Ruiz, J. M., Villasuso, R., Ayora, C., Canals, A., Otalora, F., 2006, Formation of natural gypsum megacrystals in Naica, Mexico: Geology, v. 35, n. 4, p. 327-330.

Gendrin, A., Mangold, N., Bibring, J.-P., Langevin, Y., Gondet, B., Poulet, F., Bonello, G., Quantin, C., Mustard, J., Arvidson, R., and LeMouelic, S., 2005, Sulfates in martian layered terrains: The OMEGA/Mars Express view: Science, v. 307, p. 15871591. 
Goldstein, R.H., Reynolds, T.J., 1994, Systematics of fluid inclusions in diagenetic minerals: Society for Sedimentary Geology Short Course 31.

Goldstein, R.H., 2001, Fluid inclusions in sedimentary and diagenetic systems: Lithos, v. 55, p. 159-193.

Goldstein, R.H., 2003, Petrographic Analysis of Fluid Inclusions In Samson, I.M., Anderson, A.J., Marshall, D.D., eds., Fluid Inclusions: Analysis and Interpretation, Mineralogical Association of Canada, Short Course Series, v. 32, p. 9-54.

Gonzalez-Ferron, 1995, Volcanes de Chile: Santiago, Chile, Instituto Geografico Militar, 733 p. 640.

Grasby, S.E., Smith, R.I., Bell, T., Forbes, D.L., 2013, Cryogenic formation of brine and sedimentary mirabilite in submergent coastal lake basin, Canadian Artic: Geochemica et Cosmoshimica Acta, v. 110, p. 13-28.

Grotzinger, J.P. Arvidson, R.E., Bell, J.F., III, Calvin, W., Clark, B.C., Fike, D.A., Golombeck, M., Greeley, R., Haldemann, A., Herkenhoff, K.E., Jolliff, B.L., Knoll, A.H., Malin, M., McClennan, S.M., Parker, T., Soderblum, L., SohlDickstein, J.N., Squyres, S.W., Tosca, N.J., and Watters, W.A., 2005, Stratigraphy and sedimentology of a dry to wet depositional system, Burns Formation, Mars: Earth and Planetary Science Letters, v. 240, p. 11-72.

Hall, D. L., Sterner, S. M., Bodnar, R. J., 1988, Freezing point depression of NaCl-KCl$\mathrm{H}_{2} 0$ solutions: Economic Geology, v. 83, p. 197- 202. 
Hardie, L.A., Smoot, J.P. and Eugster, H.P., 1978, Saline lakes and their deposits: A sedimentological approach. In Matter, A. and Tucker, M. E. eds., Modern and Ancient Lake Sediments, International Association of Sedimentology Special Publication, v. 2, p. 7-41.

Herkenhoff, K.E. and 32 others, 2004, Evidence from Opportunity’s microscopic imager for water on Meridiani Planum: Science, v. 306, p. 1727-1730.

Horita, J., Friedman, T.J., Lazar. B., Holland, H.D., 1991, The composition of Permian seawater: Geochemica et Cosomochimica Acta, v. 55, p. 417-432.

Jagniecki, E.A., Benison, K.C., 2010, Criteria for the recognition of acid-precipitated halite: Sedimentology, v. 57, p. 273-292.

Kocherla, M., 2013, Authigenic gypsum in gas-hydrate associated sediments from the east coast of India (Bay of Bengal): Acta Geologica Sinica, v. 87, n. 3, p. 749760.

Kunasz, I.A., 1978, Lithium brines, In Fifth International Symposium on Salt Northern Ohio Geological Society, Cleveland, OH., eds. Coogan, A.H., Hauber, L., v. 1, p. $115-117$

Krüger, Y., Garcia-Ruiz, J. M., Canals, A., Marti, D., Frenz, M., Van Driessche, A. E. S., 2013, Determining gypsum growth temperatures using monophase fluid inclusions-application to the giant gypsum crystals of Miaca, Mexico: Geology, v. 41, n. 2, p. 119-122. 
Latorre, C., Betancourt, J. L., Rylander, K. A., Quade, J., 2002 Vegetation invasions into absolute desert: A 45,000 yr rodent midden record from the Calama-Salar de Atacama basins, northern Chile (lat $22^{\circ}-24^{\circ} \mathrm{S}$ ): GSA Bulletin, v. 114, no. 3, p. $349-366$.

Lazar, B., Holland, H.D., 1988, The analysis of fluid inclusions in halite: Geochemica et Cosomochimica Acta. v. 52, p. 485-490.

Lowenstein T. K., 1982, Primary features in a potash evaporite deposit, the Permian Salado Formation of West Texas and New Mexico. In: C. R. Handford, R. G. Loucks and G. R. Davis (Eds.): Depositional and diagenetic spectra of evaporites: SEPM Core Workshop, no. 3, p. 276-304.

Lowenstein, T.K., Schubert, B.A., Timofeeff, M.N., 2011, Microbial communities in fluid inclusions and long-term survival in halite: GSA Today, v. 21, no. 1, p.4-9.

Lowenstein, T.K., 2012, Microorganisms in evaporites: Review of modern geomicrobiology, in Vreeland, R.H., ed., Advances in Understanding the Biology of Halophile Microorganisms, Springer, p. 117-139.

Mees, F., Carmen, C., Herrero, J., Van Ranst, E., 2012, The nature and significance of variations in gypsum crystal morphology in dry lake basins: Journal of Sedimentary Research, v. 82, p. 37-52.

Metz, J.M., Grotzinger, J.P., Rubin, D.M., Lewis, K.W., Squyres, S.W., and Bell, J.F, III, 2009, Sulfate-rich eolian and wet interdune deposits, Erebus Crater, Meridiani Planum, Mars: Journal of Sedimentary Research, v. 79, p. 246-264. 
Mormile, M.R. and Storrie-Lombardi, M.C., 2005, The use of ultraviolet excitation of native fluorescence for identifying biomarkers in halite crystals, in Hoover, R.B., Levin, G.V., Rozanov, A.Y., and Gladstone, G.R., eds., Astrobiology and Planetary Missions: Proceedings of SPIE (The International Society for Optical Engineering), v. 5906, p. 246-253.

Mormile, M. R., Biesen, M. A., Gutierrez, M. C., Ventosa, A., Pavlovich, J. B. Onstott, T. C., and Fredrickson, J. K., 2003, Isolation of Halobacterium salinarum retrieved directly from halite brine inclusions: Environmental Microbiology, v. 5, p. 1094-1102.

Naranjo, J. A., 1986. Geology and evolution of the Lastarria volcanic complex, north Chilean Andes. Unpublished Master of Philosophy Thesis, University, England.

Natalicchio, M., Pierre, F.D., Lugli, S., Lowenstein, T. K., Feiner, S. J., Ferrando, S., Manzi, V., Roveri, M., Clari, P., 2014, Did Late Miocene (Messinian) gypsum precipitate from evaporated marine brines? Insights from the Piedmont Basin (Italy): Geology, v. 42 no. 3 p. 179-182.

Norton, C. and Grant, W.D., 1988, Survival of halobacteria within fluid inclusions in salt crystals: Journal of General Microbiology, v. 134, p. 1365-1373.

Ort'l, F., Helvaci, C., Rosell, L. and Gundogan, I., 1998, Sulphate-borate relations in an evaporitic lacustrine environment: the Sultancayir Gypsum (Miocene, western Anatolia): Sedimentology, v. 45, p. 697-710.

Potter, R. W. II, Clynne, M. A., Brown, D. L., 1978, Freezing point depression of aqueous sodium chloride solutions: Economic Geology, v.73, p. 284-285. 
Risacher, F., Alonso, H., Salazar, C., 2002, Hydrochemistry of two adjacent acid saline lakes in the Andes of northern Chile: Chemical Geology, v. 187, p. 39-57.

Risacher, F., Fritz, B., 2009, Origin of salts and brine evolution of Bolivian and Chilean salars: Aquatic Geochemistry, v. 15, p. 123-157.

Roedder, E.W., 1984, Fluid inclusions: Washington, D.C., Mineralogical Society of America, Reviews in Mineralogy, 12, 644 p.

Sabouraud-Rosset C., 1969, Characters morphologiues des cavites primaries des monocristaux sur L'example du gypse de synthese: Bull. De Academic des Science, comptes rendus t. 268, serie D, p. 749-751.

Schopf, J.W., Farmer, J.D., Foster, I.S., Kudryavtsev, A.B., Gallardo, V.A., and Espinoza, C., 2012, Gypsum-permineralized microfossils and their relevance to the search for life on Mars: Astrobiology, v. 12, p. 619-633.

Schubert, B.A., Lowenstein, T.K., Timofeeff, M.N., and Parker, M.A., 2009a, How do prokaryotes survive in fluid inclusions in halite for 30,000 years?: Geology, v. 37, p. $1059-1062$.

Schubert, B.A., Lowenstein, T.K., Timofeeff, M.N., 2009 Microscopic identification of prokaryotes in modern and ancient halite, Saline Valley and Death Valley, California: Astrobiology, v. 9, no. 5, p. 467-482.

Schubert, B.A., Lowenstein, T.K., Timofeeff, M.N., Parker, M.A., 2010, Halophilic Archea cultured from ancient halite, Death Valley, California: Environmental Microbiology, v. 12, no. 2, p. 440-454. 
Schubert, B.A., Timofeeff, M.N., Lowenstein, T.K., and Polle, J.E.W., 2010, Dunaliella cells in fluid inclusions in halite: Significance for long-term survival of prokaryotes: Geomicrobiology Journal, v. 27, p. 61-75.

Schreiber, B.C., Hsu, K.J., 1980, Evaporites. In Hobson, G.D. eds., Developments in petroleum geology, v. 2, p. 87-138.

Schreiber B. C., Roth M. S. and Helman M. L. 1982, Recognition of primary facies characteristics of evaporites and the differentiation of these forms from diagenetic overprints. In: C. R. Hondford, R. G Loucks and G. R. Davies (Eds.), Depositional and diagenetic spectra of evaporites- A core workshop: SEPM Core Workshop no. 3. Calgary, Canada, p. 1-32.

de Silva, S. L., Francis, P. W., 1991, Volcanoes of the Central Andes, 216 p.

Smoot, J.P., and Castens-Seidell, B., 1994, Sedimentary features produced by efflorescent salt crusts, Saline Valley and Death Valley, California, in Renaut, R. and Last, W.M., eds., Sedimentology and geochemistry of modern and ancient lakes: Society for Sedimentary Geology (SEPM) Special Publication 50, p. $73-$ 90, doi:10.2110/pec.94.50.0073.

Spencer, R.J., Moller, N., Weare, J.H., 1990, The prediction of mineral solubilities in natural-waters - a chemical-equilibrium model for the NA-K-Ca-Mg-Cl-SO $\mathrm{SO}_{4}-\mathrm{H}_{2} \mathrm{O}$ system at temperatures below 25-degrees-C. Geochemica et Cosomochimica Acta, v. 54, no. 3, p. 575-590. 
Squyres, S.W. Grotzinger, J.P., Arvidson, R.E., Bell, J.F., III, Calvin, W., Christensen, P.R., Clark, B.C., Crisp, J.A., Farrand, W.H., Herkenhoff, K.E., Johnson, J.R., Klingelhofer, G., Knoll, A.H., McClennan, S.M., McSween,, H.Y., Morris, R.V., Rice, J.W., Rieder, R., and Soderblom, L.A., 2004, In situ evidence for an ancient aqueous environment at Meridiani Planum, Mars: Science, v. 306, p. 1709-1714.

Squyres, S. W. and 26 others, 2012, Ancient impact and aqueous processes at Endeavor Crater, Mars: Science, v. 336, p. 570-576.

Stoertz, G.E., and Ericksen, G.E., 1974, Geology of salars in northern Chile: U.S. Geological Survey Professional Paper 811, 65 p.

Van Driessche, A. E. S., Garcia-Ruiz, J. M., Tsukamoto, K., Patiño-Lopez, L. D., Satoh, H., 2011, Ultraslow growth rates of giant gypsum crystals: Proceedings of the National Academy of Sciences of the United States of America, v. 108, no. 38, p.15721-15726.

Vitek, P., Camara-Gallego, B., Edwards, H.G.M., Jehlicka, J., Ascaso, C., and Wierzchos, J., 2013, Phototropic community in gypsum crust from the Atacama Desert studied by Raman spectroscopy and microscopic imaging: Geomicrobiology Journal, v. 30, p. 399-410.

Vreeland, R.H., Rosenzweig, W.D., and Powers, D.W., 2000, Isolation of a 250 millionyear-old halotolerant bacterium from a primary salt crystal: Nature, v. 407, p. 897-900. 
Vreeland, R.H., Jones, J., Monson, A., Rosenzweig, W.D., Lowenstein, T.K., Timofeeff, M.J., Satterfield, C., Cho, B.C., Park, J.S., Wallace, A. and Grant, W.D., 2007, Isolation of live Cretaceous (121-112 million years old) halophilic Archaea from primary salt crystals: Geomicrobiology Journal, v. 78, p. 275-82.

Warren J. K., 1982, The hydrological setting, occurrence and significance of gypsum in late Quaternary salt lakes in South Australia: Sedimentology, vol. 29, p. 609-637. 
Karmanocky, F. J. III, 2014

Appendix A: GSA Repository 2014220 
Karmanocky, F. J. III, 2014

\section{Could microorganisms be preserved in Mars gypsum? Insights from terrestrial examples}

As a result of excitation by the UV-vis light $(330 \mathrm{~nm}$ UV and $385 \mathrm{~nm}$ visible light sources attached to our microscope), the energy can be absorbed and cause electrons in the outermost shell of a molecule to be excited. The spontaneous emission of photons returns the molecule to its relaxed state. The emission of photons may produce fluorescence. Typically, this emitted light is at longer wavelengths than the excited UVvis wavelengths (of $330 \mathrm{~nm}$ and $385 \mathrm{~nm}$ here). Many biomolecules, especially those with a high degree of conjugation, fluoresce when exposed to UV-vis light. The color of fluorescence corresponds to the wavelength of emitted light from the organic molecule. Emission of light at $\sim 455-485 \mathrm{~nm}$ results in blue fluorescence. Green fluorescence indicates $\sim 500-550 \mathrm{~nm}$ light. Orange and red fluorescence occur from $\sim 600-650 \mathrm{~nm}$ and $\sim 650-700 \mathrm{~nm}$ light, respectively. Therefore, seeing blue through the microscope indicates the presence of fluorescence in the $\sim 455-485 \mathrm{~nm}$ wavelength range.

The fluorescent response, including the wavelength and the intensity of color, is dependent upon the type of organic molecule, the concentration of the biological material, and the absorption wavelength range. The $330 \mathrm{~nm}$ UV- $385 \mathrm{~nm}$ visible light we use in this study as an excitation source is not able to cause fluorescence in all biomolecules.

A wealth of literature in the fields of biology and physics in recent years has identified the wavelength ranges at which particular biomolecules (such as biofilms, chlorophyll, bacterial polysaccharide coatings, and the decay products of these biomolecules) fluoresce given excitation by different UV-vis absorption wavelengths. For 
example, Scott (2001) has determined specific fluorescent response of various types of carotenoids (such as beta-carotene) by different absorption wavelengths.

As a result of different studies, we have found, together with colleagues, that we can conduct transmitted light and UV-vis microscopy, followed by laser Raman spectroscopy, to identify individual organic suspects within fluid inclusions in halite and gypsum. For example, Conner and Benison (2013) report orange-pink fluoresence (in response to UV-vis light in the same wavelengths we use for this study) for the same specific rounded masses and crystals that have the distinct Raman spectra of betacarotene. Therefore, in the Conner and Benison (2013) study, we interpreted those objects in fluid inclusions to be beta-carotene. Likewise, studies by Benison et al. (2008), Mormile and Storrie-Lombardi (2005), Schubert et al., (2009a, 2010) paired transmitted light and UV-vis microscopy with a biological or chemical identification method (laser Raman microscopy and/or molecular laboratory techniques such as isolation, culturing, and enrichment and DGGE) to characterize the fluorescence colors of prokaryotes, eukaryotes, and some organic compounds such as some carotenoids within fluid inclusions in halite. Results of these studies suggest that most prokaryotes fluoresce green or green-blue, Dunaliella algae fluoresces blue, and beta-carotene fluoresces orange-red. 
Karmanocky, F. J. III, 2014

\section{REFERENCES CITED}

Benison, K.C., Jagniecki, E.A., Edwards, T.B., Mormile, M.C., and Storrie-Lombardi, M.C., 2008, "Hairy blobs": Microbial suspects from modern and ancient ephemeral acid saline evaporites: Astrobiology, v. 8, n. 4, p. 807-821.

Scott, K.J., 2001, Detection and measurement of carotenoids by UV/VIS spectrophotometry: Current Protocols in Food Analytical Chemistry, F2.2.1 F2.2.10. 
Karmanocky, F. J. III, 2014

Appendix B: Salars Gorbea and Ignorado Chemistry Data 
Chemical composition of Gorbea and Ignorado waters

(Risacher et al., 2002)

\begin{tabular}{c|cccccc} 
& & & & & & \\
Sample & $\mathrm{T}\left({ }^{\circ} \mathrm{C}\right)$ & Density & $\mathrm{pH}$ field & $\mathrm{pH}$ lab & Alkal acid & $\mathrm{O} 2$ \\
\hline & & & & & & $\mathrm{mmol} / \mathrm{L}$ \\
\hline \hline Gor-1 & 17.3 & 1.002 & 7.19 & 7.57 & -1.09 & 0.17 \\
Gor-2 & 10 & 1.005 & 3.64 & 3.69 & -0.37 & 0.13 \\
Gor-3 & 8.8 & 1.008 & 4.17 & 4.17 & -0.13 & 0.18 \\
Gor-4 & 14 & 1.023 & 2.02 & 2 & -18.8 & 0.14 \\
Gor-5 & 18 & 1.101 & 1.32 & 1.32 & -60.4 & 0.09 \\
Gor-6 & 10 & 1.003 & 7.22 & 7.36 & 0.425 & 0.19 \\
Gor-7 & 11.7 & 1.011 & 3.87 & 3.9 & -0.18 & 0.16 \\
Gor-8 & 22 & 1.006 & 3.57 & 3.59 & -0.36 & 0.19 \\
Gor-9 & 15.1 & 1.029 & 3.21 & 3.29 & -0.62 & 0.13 \\
Gor-10 & 11.2 & 1.003 & 4.26 & 4.33 & -0.05 & 0.11 \\
Gor-11 & 14.7 & 1.225 & 1.61 & 1.77 & -8.61 & 0.02 \\
Gor-12 & 16.6 & 1.22 & 2.05 & 2.17 & -2.08 & 0.01 \\
& & & & & & \\
Ign-1 & 8.8 & 1.004 & 3.88 & 3.91 & -0.11 & 0.27 \\
Ign-2 & 9 & 1.086 & 2.65 & 2.81 & -5.32 & 0.12 \\
Ign-3 & 11.5 & 1.012 & 3.28 & 3.3 & -1.15 & 0.17 \\
Ign-4 & 14 & 1.009 & 3.06 & 2.94 & -2.36 & 0.17 \\
Ign-5 & 10.5 & 1.012 & na & 4.16 & -0.2 & 0.17 \\
& & & & & &
\end{tabular}


Chemical composition of Gorbea and Ignorado waters

(Risacher et al., 2002)

\begin{tabular}{c|cccccc} 
& \multicolumn{7}{|c}{ } & \multicolumn{7}{c}{$\mathrm{Br}$} & $\mathrm{SO} 4$ \\
\hline Sample & $\mathrm{m} l$ & $\mathrm{mg} / \mathrm{L}$ & $\mathrm{mmol} / \mathrm{L}$ & $\mathrm{mg} / \mathrm{L}$ & $\mathrm{mmol} / \mathrm{L}$ \\
\hline \hline & 5.31283205 & 3.36 & 94.7813822 & 0.001 & 0.01251502 & 21.8 \\
Gor-2 & 4.06275392 & 54.5 & 1537.37659 & 0.041 & 0.51311574 & 17.9 \\
Gor-3 & 5.62535158 & 111 & 3131.17066 & 0.086 & 1.07629155 & 23.8 \\
Gor-4 & 4.37527345 & 258 & 7277.85614 & 0.048 & 0.60072087 & 102 \\
Gor-5 & 2.81267579 & 1350 & 38081.8054 & 0.226 & 2.82839407 & 435 \\
Gor-6 & 5.93787112 & 5.63 & 158.815233 & 0.002 & 0.02503004 & 17.8 \\
Gor-7 & 5.00031252 & 112 & 3159.37941 & 0.009 & 0.11263516 & 49.3 \\
Gor-8 & 5.93787112 & 104 & 2933.70945 & 0.105 & 1.31407689 & 12.9 \\
Gor-9 & 4.06275392 & 506 & 14273.6248 & 0.274 & 3.42911494 & 65.3 \\
Gor-10 & 3.43771486 & 46.4 & 1308.88575 & 0.053 & 0.66329596 & 5.19 \\
Gor-11 & 0.62503906 & 3450 & 97320.1693 & 0.112 & 1.40168202 & 893 \\
Gor-12 & 0.31251953 & 3490 & 98448.519 & 0.08 & 1.00120144 & 841 \\
& & & & & & \\
Ign-1 & 8.43802738 & 4 & 112.834979 & 0.0011 & 0.01376652 & 28.6 \\
Ign-2 & 3.75023439 & 141 & 3977.433 & na & --- & 683 \\
Ign-3 & 5.31283205 & 17 & 479.54866 & 0.0018 & 0.02252703 & 92.7 \\
Ign-4 & 5.31283205 & 12.5 & 352.609309 & 0.0019 & 0.02377853 & 67.6 \\
Ign-5 & 5.31283205 & 39.6 & 1117.06629 & 0.0051 & 0.06382659 & 76
\end{tabular}


Chemical composition of Gorbea and Ignorado waters

(Risacher et al., 2002)

\begin{tabular}{c|cccccc} 
& \multicolumn{7}{|c}{ mi } & Si & mmol/L \\
\hline Sample & mg $/ \mathrm{L}$ & $\mathrm{mmol} / \mathrm{L}$ & $\mathrm{mg} / \mathrm{L}$ & $\mathrm{mmol} / \mathrm{L}$ & $\mathrm{L}$ & $\mathrm{mm}$ \\
\hline \hline & 226.950945 & 0.49 & 45.3283996 & 1.06 & 37.7425672 & 0.0002 \\
Gor-2 & 186.349629 & 3.6 & 333.024977 & 2.08 & 74.0608866 & 0.00026 \\
Gor-3 & 247.772133 & 7.19 & 665.124884 & 2.67 & 95.0685419 & 0.00012 \\
Gor-4 & 1061.88057 & 13.3 & 1230.34228 & 1.95 & 69.4320812 & 0.041 \\
Gor-5 & 4528.60831 & 34.7 & 3209.99075 & 4.42 & 157.379384 & 0.14 \\
Gor-6 & 185.30857 & 0.63 & 58.279371 & 1.72 & 61.2426562 & 0.0053 \\
Gor-7 & 513.242275 & 6.6 & 610.545791 & 2.36 & 84.0306213 & 0.00003 \\
Gor-8 & 134.29666 & 6.83 & 631.822387 & 4.53 & 161.296066 & 0.00074 \\
Gor-9 & 679.811776 & 28.7 & 2654.94912 & 4.78 & 170.197614 & 0.0014 \\
Gor-10 & 54.0309819 & 3.09 & 285.846438 & 2.32 & 82.6063735 & 0.00067 \\
Gor-11 & 9296.66028 & 149 & 13783.5338 & 2.11 & 75.1290725 & 0.0028 \\
Gor-12 & 8755.3094 & 146 & 13506.013 & 1.81 & 64.4472138 & 0.00018 \\
& & & & & & \\
Ign-1 & 297.742983 & 0.31 & 28.6771508 & 1.55 & 55.189603 & 0.00009 \\
Ign-2 & 7110.43558 & 17.9 & 1655.87419 & 4.12 & 146.697525 & 0.0036 \\
Ign-3 & 965.062047 & 1.77 & 163.73728 & 2.66 & 94.71248 & 0.00065 \\
Ign-4 & 703.756142 & 1.67 & 154.486586 & 4.68 & 166.636995 & 0.0021 \\
Ign-5 & 791.20513 & 2.7 & 249.768733 & 4.51 & 160.583942 & 0.0084
\end{tabular}


Chemical composition of Gorbea and Ignorado waters

(Risacher et al., 2002)

\begin{tabular}{c|cccccc} 
& \multicolumn{7}{|c}{ K } & $\mathrm{K}$ & $\mathrm{Li}$ \\
\hline & $\mathrm{mam} / \mathrm{L}$ & $\mathrm{mmol} / \mathrm{L}$ & $\mathrm{mg} / \mathrm{L}$ & $\mathrm{mmol} / \mathrm{L}$ & $\mathrm{mg} / \mathrm{L}$ & $\mathrm{mmol} / \mathrm{L}$ \\
\hline \hline & 0.00266944 & 13.8 & 600.260983 & 1.1 & 28.1344314 & 0.046 \\
Gor-2 & 0.00347028 & 48.9 & 2127.01174 & 2.45 & 62.6630518 & 0.722 \\
Gor-3 & 0.00160167 & 104 & 4523.70596 & 5.11 & 130.697222 & 1.61 \\
Gor-4 & 0.54723579 & 188 & 8177.46846 & 12 & 306.92107 & 3.45 \\
Gor-5 & 1.86861002 & 950 & 41322.314 & 65.1 & 1665.04681 & 17.8 \\
Gor-6 & 0.07074024 & 11 & 478.4689 & 1.23 & 31.4594097 & 0.058 \\
Gor-7 & 0.00040042 & 80.9 & 3518.92127 & 3.37 & 86.1936672 & 1.28 \\
Gor-8 & 0.00987694 & 90.7 & 3945.19356 & 3.81 & 97.4474398 & 1.47 \\
Gor-9 & 0.0186861 & 420 & 18268.8125 & 17.5 & 447.593227 & 6.99 \\
Gor-10 & 0.00894263 & 43 & 1870.37843 & 1.74 & 44.5035552 & 0.657 \\
Gor-11 & 0.0373722 & 2130 & 92648.9778 & 148 & 3785.35986 & 44.9 \\
Gor-12 & 0.0024025 & 2220 & 96563.7234 & 108 & 2762.28963 & 47.3 \\
& & & & & & \\
Ign-1 & 0.00120125 & 13.1 & 569.812962 & 2.15 & 54.9900251 & 0.066 \\
Ign-2 & 0.04804997 & 571 & 24836.8856 & 103 & 2634.40585 & 2.12 \\
Ign-3 & 0.00867569 & 68.6 & 2983.90605 & 11.6 & 296.690368 & 0.274 \\
Ign-4 & 0.02802915 & 53.4 & 2322.74902 & 8.74 & 223.540846 & 0.173 \\
Ign-5 & 0.1121166 & 89.4 & 3888.64724 & 16.3 & 416.90112 & 0.317
\end{tabular}


Chemical composition of Gorbea and Ignorado waters

(Risacher et al., 2002)

\begin{tabular}{c|cccccc} 
& \multicolumn{7}{|c}{$\mathrm{Mg}$} & $\mathrm{Al}$ \\
Sample & $\mathrm{ma}$ & $\mathrm{mg} / \mathrm{L}$ & $\mathrm{mmol} / \mathrm{L}$ & $\mathrm{mg} / \mathrm{L}$ & $\mathrm{mmol} / \mathrm{L}$ \\
\hline \hline & 6.62824207 & 12 & 299.416139 & 4.94 & 203.25036 & $\mathrm{nd}$ \\
Gor-2 & 104.034582 & 11.9 & 296.921004 & 5.35 & 220.119317 & 0.829 \\
Gor-3 & 231.988473 & 14.6 & 364.289635 & 7.3 & 300.349722 & 1.26 \\
Gor-4 & 497.118156 & 9.91 & 247.267828 & 81.7 & 3361.44826 & 17.4 \\
Gor-5 & 2564.8415 & 15.6 & 389.24098 & 386 & 15881.5059 & 85.9 \\
Gor-6 & 8.3573487 & 11.3 & 281.950197 & 3.87 & 159.226497 & $\mathrm{nd}$ \\
Gor-7 & 184.43804 & 14.3 & 356.804232 & 39.1 & 1608.72249 & 4.54 \\
Gor-8 & 211.815562 & 10.5 & 261.989121 & 3.4 & 139.888912 & 0.518 \\
Gor-9 & 1007.20461 & 26.2 & 653.725236 & 49.6 & 2040.73236 & 8.04 \\
Gor-10 & 94.6685879 & 5.05 & 126.004292 & 0.442 & 18.1855585 & 0.089 \\
Gor-11 & 6469.74063 & 6.11 & 152.452717 & 1110 & 45669.6153 & 169 \\
Gor-12 & 6815.56196 & 5.99 & 149.458556 & 1150 & 47315.3672 & 140 \\
& & & & & & \\
Ign-1 & 9.51008646 & 11.7 & 291.930735 & 7.51 & 308.98992 & 2.47 \\
Ign-2 & 305.475504 & 13.2 & 329.357752 & 237 & 9751.08002 & 108 \\
Ign-3 & 39.481268 & 11.2 & 279.455063 & 29.7 & 1221.97079 & 13.2 \\
Ign-4 & 24.9279539 & 12.1 & 301.911273 & 18.3 & 752.931496 & 7.2 \\
Ign-5 & 45.6772334 & 12.6 & 314.386945 & 29.1 & 1197.28451 & 0.725
\end{tabular}


Chemical composition of Gorbea and Ignorado waters

(Risacher et al., 2002)

\begin{tabular}{c|cccccc} 
& \multicolumn{7}{|c}{ Mn } & Zn \\
Sample & me & mmol/L & mg/L & mmol/L & mg/L & mmol/L \\
\hline \hline & --- & nd & \#VALUE! & nd & --- & nd \\
Gor-2 & 30.7241865 & 0.0018 & 0.03223207 & 0.055 & 1.00112854 & 0.004 \\
Gor-3 & 46.6977985 & 0.0005 & 0.00895335 & 0.065 & 1.18315192 & 0.007 \\
Gor-4 & 644.874361 & 0.487 & 8.72056585 & 0.728 & 13.2513015 & 0.061 \\
Gor-5 & 3183.60388 & 2.6 & 46.5574358 & 3.37 & 61.3418763 & 0.145 \\
Gor-6 & --- & nd & \#VALUE! & nd & --- & nd \\
Gor-7 & 168.260322 & 0.0009 & 0.01611604 & 0.282 & 5.13305908 & 0.024 \\
Gor-8 & 19.1979838 & 0.0039 & 0.06983615 & 0.033 & 0.60067713 & 0.003 \\
Gor-9 & 297.976429 & 0.178 & 3.18739368 & 0.491 & 8.93734756 & 0.04 \\
Gor-10 & 3.29849529 & 0.0003 & 0.00537201 & 0.004 & 0.07280935 & 0.002 \\
Gor-11 & 6263.43488 & 0.134 & 2.39949861 & 8.37 & 152.353562 & 0.78 \\
Gor-12 & 5188.64428 & 0.018 & 0.32232071 & 8.92 & 162.364848 & 0.841 \\
& & & & & & 0.048 \\
Ign-1 & 91.5425098 & 0.0016 & 0.02865073 & 0.043 & 0.7827005 & 0.005 \\
Ign-2 & 4002.66845 & 0.913 & 16.3488226 & 1.71 & 31.1259966 & 0.103 \\
Ign-3 & 489.215032 & 0.025 & 0.44766765 & 0.218 & 3.96810951 & 0.012 \\
Ign-4 & 266.844563 & 0.086 & 1.53997672 & 0.091 & 1.65641268 & 0.076 \\
Ign-5 & 26.869765 & 0.0045 & 0.08058018 & 0.1 & 1.82023372 & 0.01
\end{tabular}


Chemical composition of Gorbea and Ignorado waters

(Risacher et al., 2002)

\begin{tabular}{c|cc} 
& & \\
Sample & & TDS \\
\hline \hline & mg/L & \\
\hline Gor-2 & 0.06118079 & 5620 \\
Gor-3 & 0.10706638 & 9800 \\
Gor-4 & 0.93300704 & 26900 \\
Gor-5 & 2.21780361 & 127000 \\
Gor-6 & --- & 2850 \\
Gor-7 & 0.36708474 & 12500 \\
Gor-8 & 0.04588559 & 7910 \\
Gor-9 & 0.61180789 & 37600 \\
Gor-10 & 0.03059039 & 3530 \\
Gor-11 & 11.9302539 & 297000 \\
Gor-12 & 12.8632609 & 294000 \\
& & \\
Ign-1 & 0.07647599 & 4050 \\
Ign-2 & 1.57540532 & 97400 \\
Ign-3 & 0.18354237 & 13200 \\
Ign-4 & 1.162435 & 9800 \\
Ign-5 & 0.15295197 & 12900 \\
& &
\end{tabular}


Karmanocky, F. J. III, 2014

Appendix C: Microthermometry Results 


\begin{tabular}{|c|c|c|c|c|}
\hline FIA No. & $\begin{array}{c}\text { Fluid Inclusion } \\
\text { No. }\end{array}$ & Teu & Tm, ice & Calc. Salinity \\
\hline \multirow{5}{*}{1} & 1 & -34.3 & -1.5 & $2.6 \%$ \\
\hline & 2 & -33.4 & -1.4 & $2.4 \%$ \\
\hline & 3 & -35 & -2.3 & $3.9 \%$ \\
\hline & 4 & -34.8 & -1.6 & $2.7 \%$ \\
\hline & 5 & -34.4 & -1 & $1.7 \%$ \\
\hline \multirow{4}{*}{2} & 1 & -30.3 & -1.8 & $3.1 \%$ \\
\hline & 2 & -33 & -1.9 & $3.2 \%$ \\
\hline & 3 & -35.6 & -2.4 & $4 . \%$ \\
\hline & 4 & -34.4 & -2 & $3.4 \%$ \\
\hline \multirow{3}{*}{3} & 1 & -29.3 & -1.7 & $2.9 \%$ \\
\hline & 2 & -20 & -2.5 & $4.2 \%$ \\
\hline & 3 & -25.3 & -2 & $3.4 \%$ \\
\hline \multirow{5}{*}{4} & 1 & -34.2 & -1.7 & $2.9 \%$ \\
\hline & 2 & -35 & -1.9 & $3.2 \%$ \\
\hline & 3 & -35.3 & -2.4 & $4 . \%$ \\
\hline & 4 & -30.1 & -1.9 & $3.2 \%$ \\
\hline & 5 & -36.7 & -1.8 & $3.1 \%$ \\
\hline \multirow{2}{*}{5} & 1 & -34.4 & -1.7 & $2.9 \%$ \\
\hline & 2 & -35.3 & -1.4 & $2.4 \%$ \\
\hline
\end{tabular}


Karmanocky, F. J. III, 2014

\begin{tabular}{|c|c|c|c|c|}
\hline & 3 & -40.1 & -3.2 & $5.3 \%$ \\
\hline & 4 & -26.2 & -2.8 & $4.6 \%$ \\
\hline & 5 & -33.3 & -2.1 & $3.5 \%$ \\
\hline & 6 & -32.8 & -2.3 & $3.9 \%$ \\
\hline \multirow{2}{*}{6} & 1 & -33.9 & -1.7 & $2.9 \%$ \\
\hline & 2 & -39.4 & -3.1 & $5.1 \%$ \\
\hline \multirow{4}{*}{7} & 1 & -50 & -20.5 & $22.7 \%$ \\
\hline & 2 & -49.9 & -17.9 & $20.9 \%$ \\
\hline & 3 & -52 & -23.5 & $24.6 \%$ \\
\hline & 4 & -52.4 & -24 & $25 . \%$ \\
\hline \multirow{6}{*}{8} & 1 & -51 & -23.8 & $24.8 \%$ \\
\hline & 2 & -52 & -24.7 & $25.4 \%$ \\
\hline & 3 & -51.7 & -23.2 & $24.5 \%$ \\
\hline & 4 & -50.2 & -21 & $23 . \%$ \\
\hline & 5 & -37.9 & -15 & $18.6 \%$ \\
\hline & 6 & -41.3 & -25.1 & $25.6 \%$ \\
\hline \multirow{4}{*}{9} & 1 & -51 & -24.5 & $25.3 \%$ \\
\hline & 2 & -53.2 & -24.7 & $25.4 \%$ \\
\hline & 3 & -48.9 & -23.2 & $24.5 \%$ \\
\hline & 4 & -49.6 & -24.5 & $25.3 \%$ \\
\hline \multirow{2}{*}{10} & 1 & -62.4 & -24.9 & $25.5 \%$ \\
\hline & 2 & -53 & -22.3 & $23.9 \%$ \\
\hline
\end{tabular}


Karmanocky, F. J. III, 2014

\begin{tabular}{|c|c|c|c|c|}
\hline & 3 & -52.9 & -22.5 & $24 . \%$ \\
\hline & 4 & -54.1 & -23.3 & $24.5 \%$ \\
\hline & 5 & -54.6 & -23.8 & $24.8 \%$ \\
\hline 11 & \multicolumn{4}{|c|}{ No viable fluid inclusions to evaluate } \\
\hline \multirow{4}{*}{12} & 1 & -62 & -28 & $27.4 \%$ \\
\hline & 2 & -55 & -27 & $26.8 \%$ \\
\hline & 3 & -56 & -27 & $26.8 \%$ \\
\hline & 4 & -55 & -27 & $26.8 \%$ \\
\hline \multirow{6}{*}{13} & 1 & -51.2 & -23.5 & $24.6 \%$ \\
\hline & 2 & -50.3 & -23 & $24.3 \%$ \\
\hline & 3 & -49 & -23.9 & $24.9 \%$ \\
\hline & 4 & -51 & -24.5 & $25.3 \%$ \\
\hline & 5 & -50.8 & -25.3 & $25.8 \%$ \\
\hline & 6 & -50.4 & -24.9 & $25.5 \%$ \\
\hline \multirow{5}{*}{14} & 1 & -50.7 & -20.6 & $22.8 \%$ \\
\hline & 2 & -50.6 & -20.5 & $22.7 \%$ \\
\hline & 3 & -51.1 & -21 & $23 . \%$ \\
\hline & 4 & -50.4 & -22.7 & $24.1 \%$ \\
\hline & 5 & -50.4 & -22.4 & $24 . \%$ \\
\hline \multirow{3}{*}{15} & 1 & -45.2 & -23.5 & $24.6 \%$ \\
\hline & 2 & -44.9 & -22.9 & $24.3 \%$ \\
\hline & 3 & -45.1 & -23 & $24.3 \%$ \\
\hline
\end{tabular}


Karmanocky, F. J. III, 2014

\begin{tabular}{|c|c|c|c|c|}
\hline & 4 & -46.7 & -24.1 & $25 . \%$ \\
\hline & 5 & -43.2 & -22.2 & $23.8 \%$ \\
\hline & 6 & -44.5 & -22.8 & $24.2 \%$ \\
\hline & 7 & -45.2 & -23.6 & $24.7 \%$ \\
\hline \multirow{6}{*}{16} & 1 & -42.5 & -23.7 & $24.8 \%$ \\
\hline & 2 & -42.2 & -22.9 & $24.3 \%$ \\
\hline & 3 & -42.3 & -22.8 & $24.2 \%$ \\
\hline & 4 & -42.6 & -23 & $24.3 \%$ \\
\hline & 5 & -41.9 & -24 & $25 . \%$ \\
\hline & 6 & -44 & -24.3 & $25.1 \%$ \\
\hline \multirow{3}{*}{17} & 1 & -40 & -3.9 & $6.3 \%$ \\
\hline & 2 & -29.3 & -3.1 & $5.1 \%$ \\
\hline & 3 & -28.9 & -2.4 & $4 . \%$ \\
\hline \multirow{3}{*}{18} & 1 & -38.5 & -1.8 & $3.1 \%$ \\
\hline & 2 & -28.9 & -1.9 & $3.2 \%$ \\
\hline & 3 & -31.1 & -0.9 & $1.6 \%$ \\
\hline \multirow{4}{*}{19} & 1 & -40 & -1.8 & $3.1 \%$ \\
\hline & 2 & -39.4 & -1.7 & $2.9 \%$ \\
\hline & 3 & -42.3 & -2.4 & $4 . \%$ \\
\hline & 4 & -44.1 & -2.3 & $3.9 \%$ \\
\hline \multirow{2}{*}{20} & 1 & -32.4 & -3.4 & $5.6 \%$ \\
\hline & 2 & -33.1 & -4.1 & $6.6 \%$ \\
\hline
\end{tabular}


Karmanocky, F. J. III, 2014

\begin{tabular}{|c|c|c|c|c|}
\hline & 3 & -32.9 & -3.8 & $6.2 \%$ \\
\hline & 4 & -34 & -3.8 & $6.2 \%$ \\
\hline \multirow{5}{*}{21} & 1 & -33.6 & -3.1 & $5.1 \%$ \\
\hline & 2 & -33.7 & -3.2 & $5.3 \%$ \\
\hline & 3 & -32.3 & -3.7 & $6 . \%$ \\
\hline & 4 & -33.3 & -3 & $5 . \%$ \\
\hline & 5 & -35 & -3 & $5 . \%$ \\
\hline \multirow{5}{*}{22} & 1 & -40.3 & -3.7 & $6 . \%$ \\
\hline & 2 & -39.9 & -3 & $5 . \%$ \\
\hline & 3 & -39.9 & -4 & $6.4 \%$ \\
\hline & 4 & -40.8 & -3.9 & $6.3 \%$ \\
\hline & 5 & -41.2 & -4.5 & $7.2 \%$ \\
\hline \multirow{4}{*}{23} & 1 & -36 & -3.3 & $5.4 \%$ \\
\hline & 2 & -37.1 & -4.1 & $6.6 \%$ \\
\hline & 3 & -36.6 & -3.8 & $6.2 \%$ \\
\hline & 4 & -36.9 & -3.7 & $6 . \%$ \\
\hline \multirow{4}{*}{24} & 1 & -33.1 & -2.8 & $4.6 \%$ \\
\hline & 2 & -34.4 & -3 & $5 . \%$ \\
\hline & 3 & -34.1 & -3.1 & $5.1 \%$ \\
\hline & 4 & -35.2 & -3.7 & $6 . \%$ \\
\hline \multirow{2}{*}{25} & 1 & -34.6 & -2.8 & $4.6 \%$ \\
\hline & 2 & -33.9 & -2.9 & $4.8 \%$ \\
\hline
\end{tabular}


Karmanocky, F. J. III, 2014

\begin{tabular}{|c|c|c|c|c|}
\hline & 3 & -33.2 & -3.3 & $5.4 \%$ \\
\hline \multirow{5}{*}{26} & 1 & -33.1 & -2.8 & $4.6 \%$ \\
\hline & 2 & -31.6 & -1.7 & $2.9 \%$ \\
\hline & 3 & -35.2 & -3.2 & $5.3 \%$ \\
\hline & 4 & -33.2 & -3.3 & $5.4 \%$ \\
\hline & 5 & -32.3 & -3.2 & $5.3 \%$ \\
\hline \multirow{6}{*}{27} & 1 & -28.6 & -4.3 & $6.9 \%$ \\
\hline & 2 & -27.9 & -4.1 & $6.6 \%$ \\
\hline & 3 & -28.7 & -4.5 & $7.2 \%$ \\
\hline & 4 & -28.3 & -5 & $7.9 \%$ \\
\hline & 5 & -28.1 & -3.5 & $5.7 \%$ \\
\hline & 6 & -30.1 & -5.3 & $8.3 \%$ \\
\hline \multirow{6}{*}{28} & 1 & -30 & -3.7 & $6 . \%$ \\
\hline & 2 & -29 & -4.1 & $6.6 \%$ \\
\hline & 3 & -29.1 & -4.4 & $7 . \%$ \\
\hline & 4 & -15.6 & -3.7 & $6 . \%$ \\
\hline & 5 & -23.2 & -4.1 & $6.6 \%$ \\
\hline & 6 & -28.7 & -4.2 & $6.7 \%$ \\
\hline
\end{tabular}


Karmanocky, F. J. III, 2014

\section{Appendix D: Photographs of low salinity freezing- melting run}


Karmanocky, F. J. III, 2014

\section{Room temperature}

Frozen

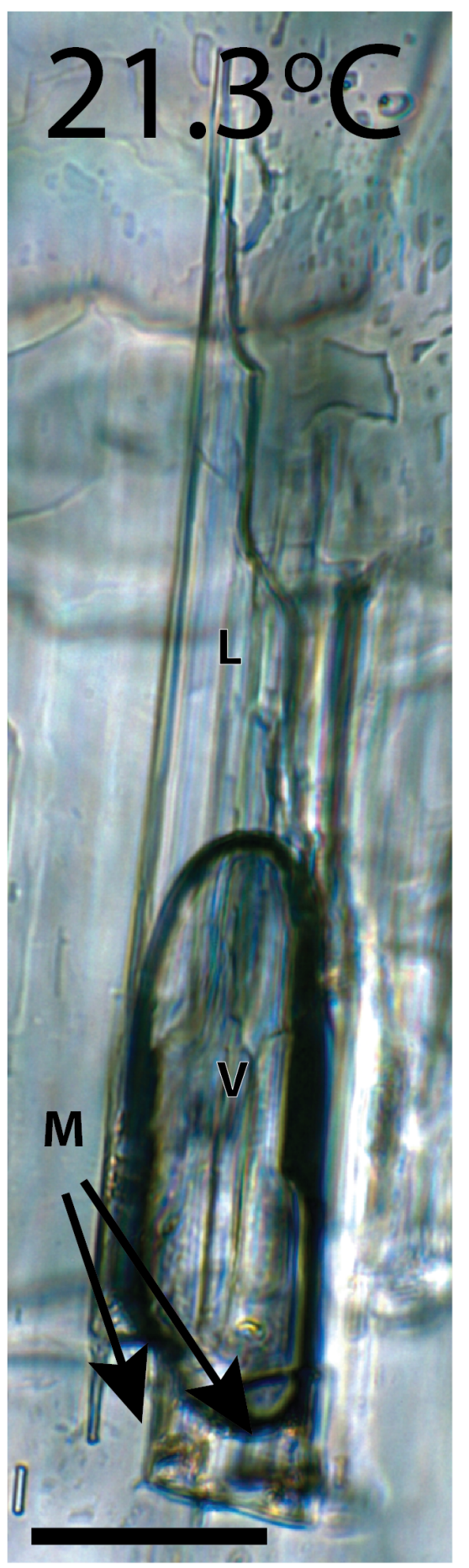

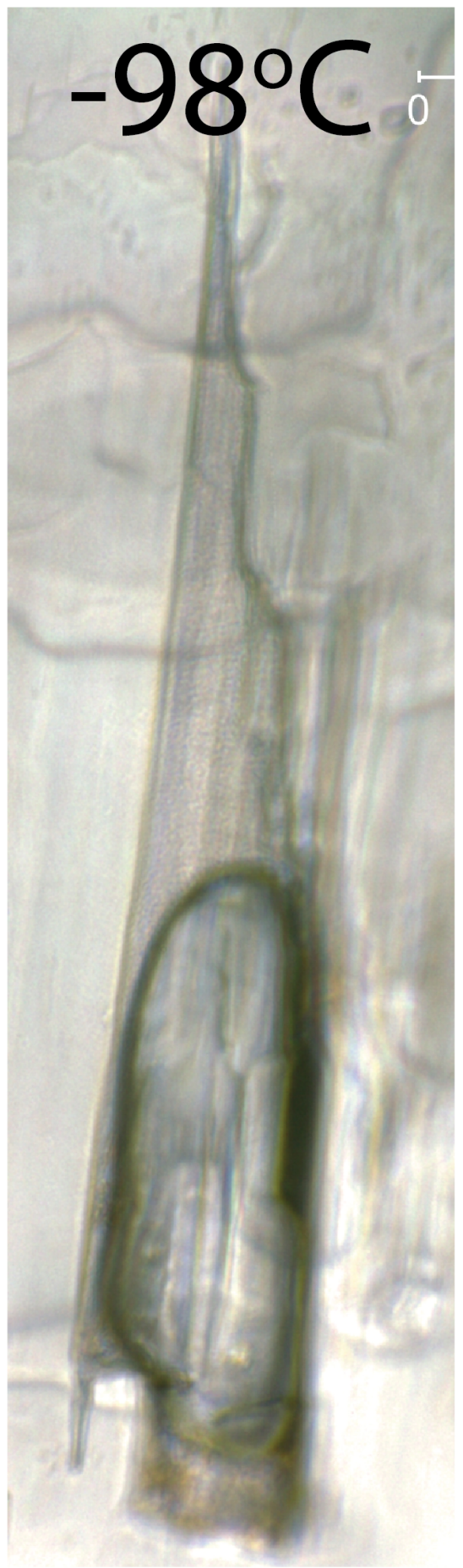

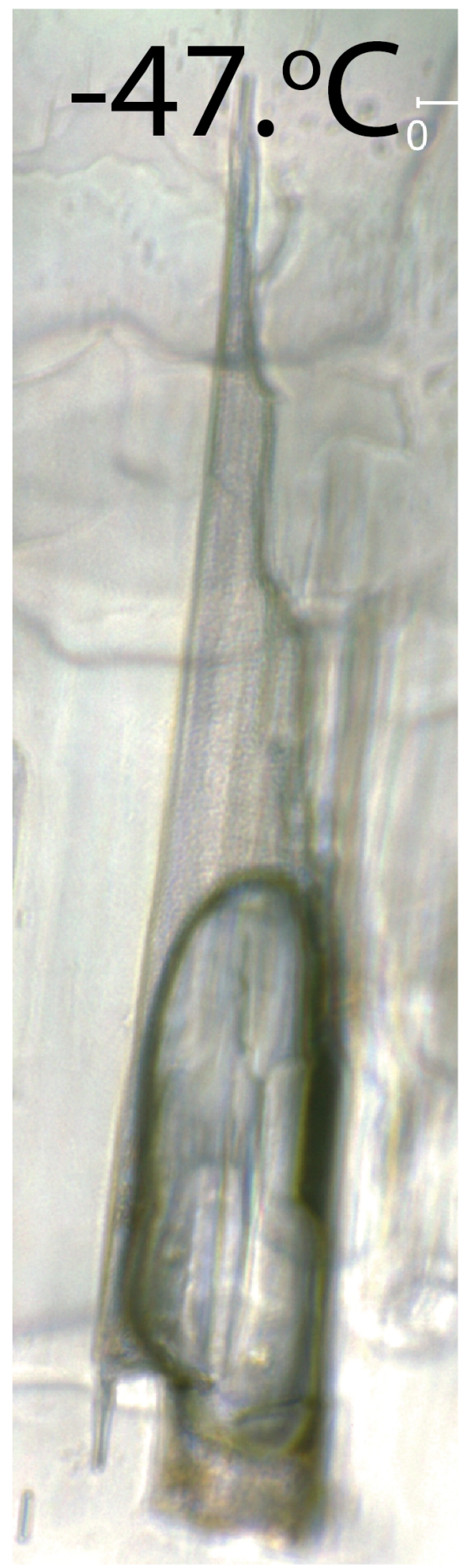


Karmanocky, F. J. III, 2014
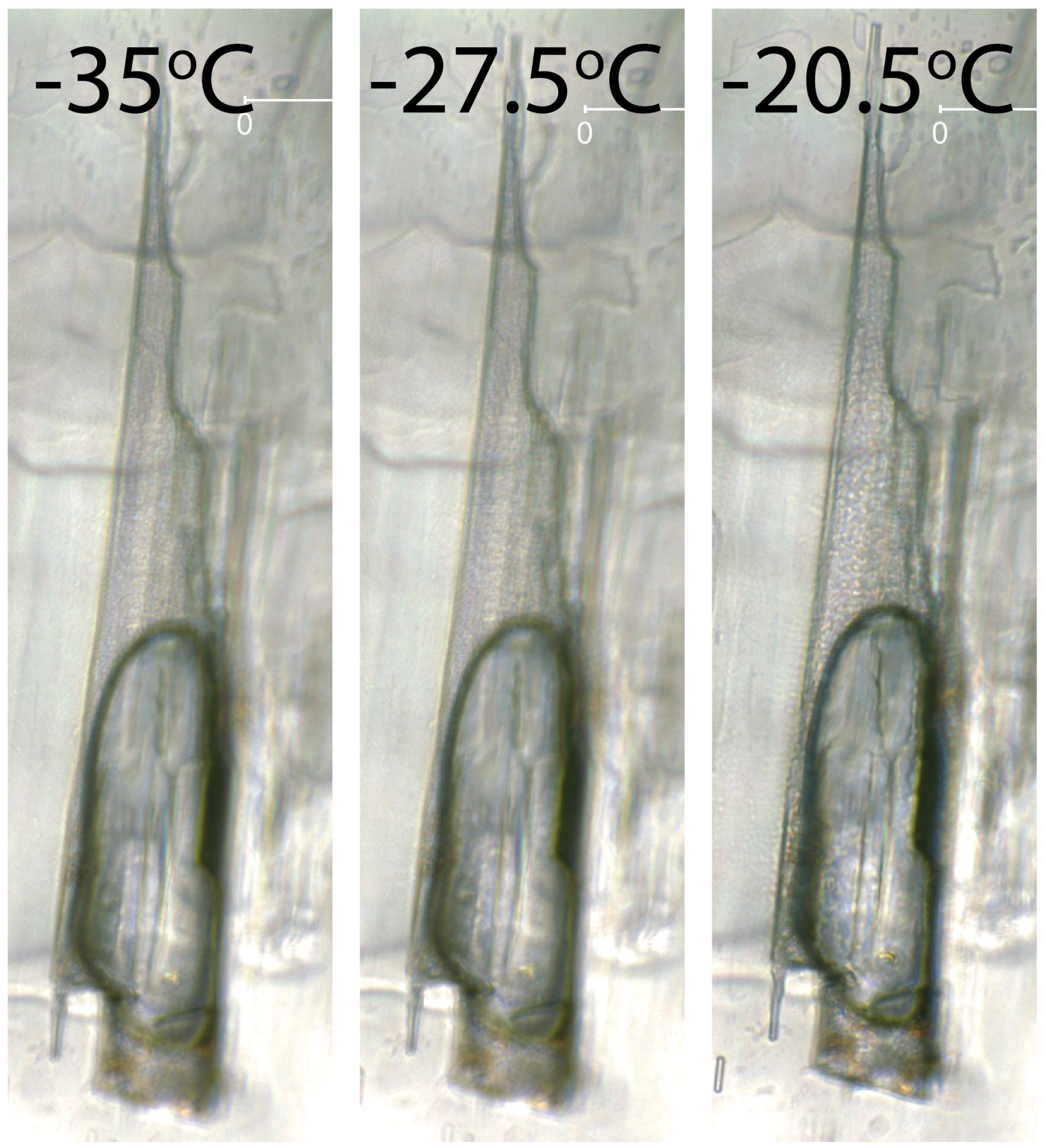
Karmanocky, F. J. III, 2014
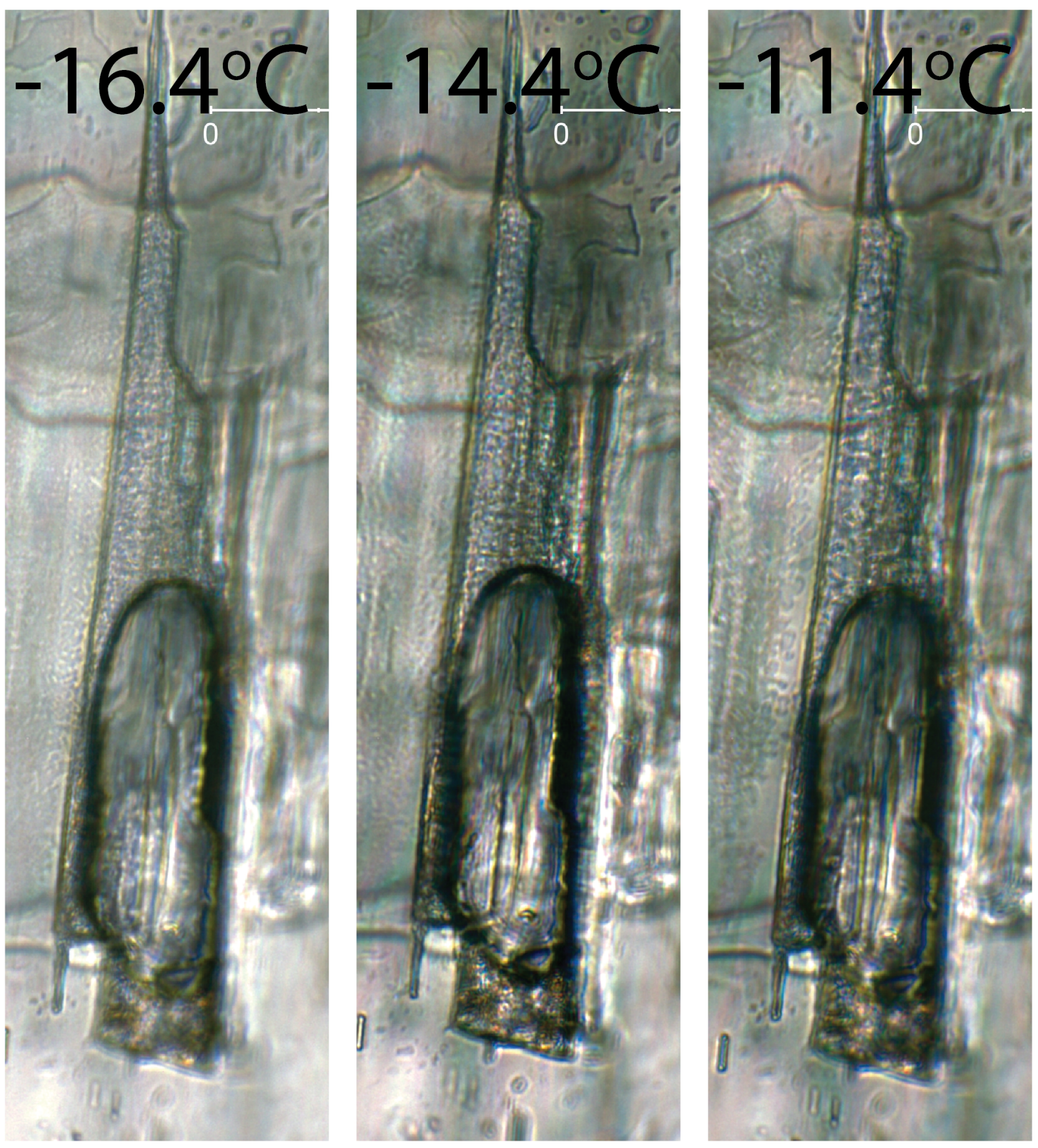
Karmanocky, F. J. III, 2014
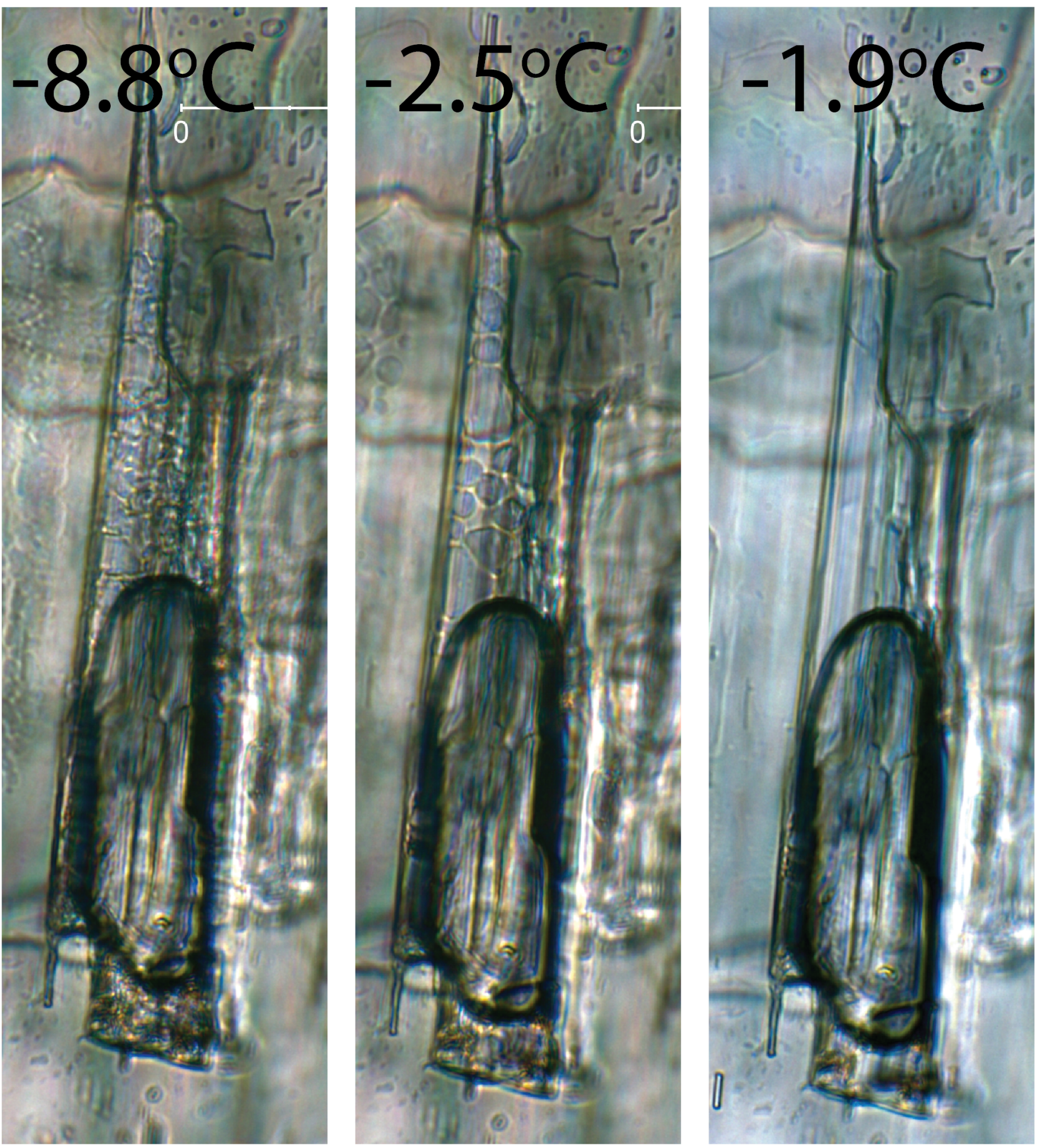
Karmanocky, F. J. III, 2014

Appendix E: Photographs of high salinity freezingmelting run 
Karmanocky, F. J. III, 2014

Room Temperature

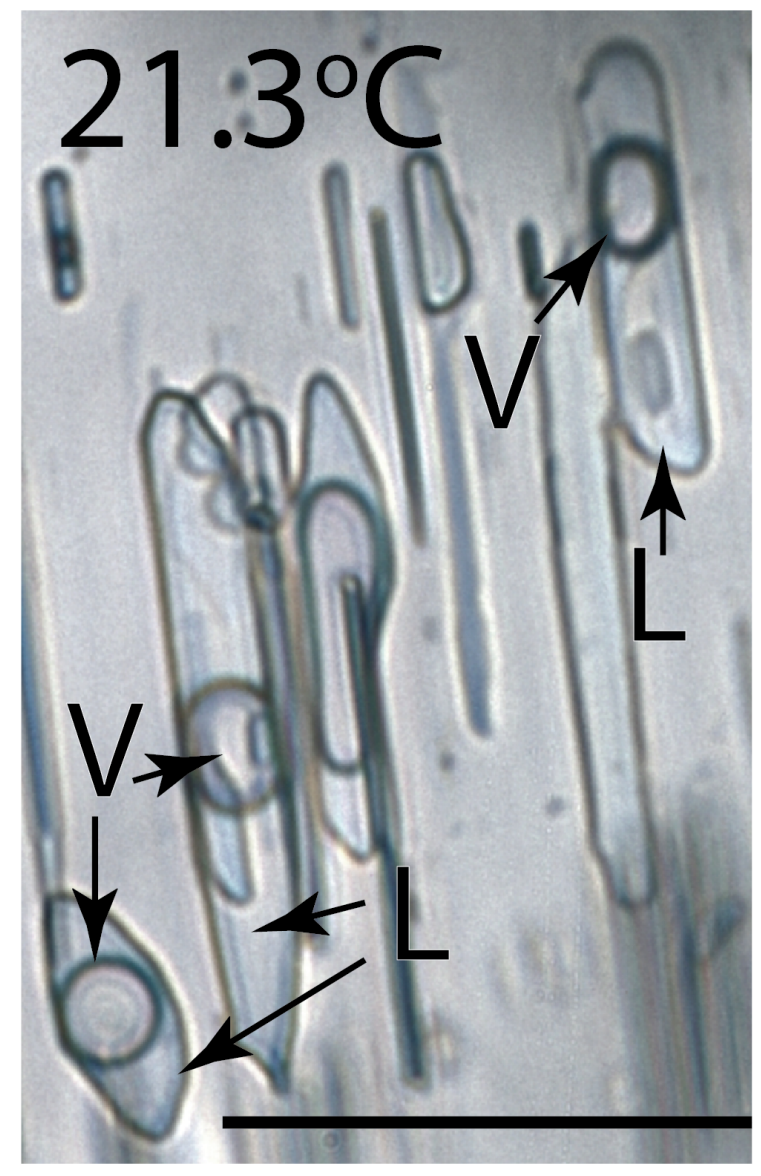

Frozen

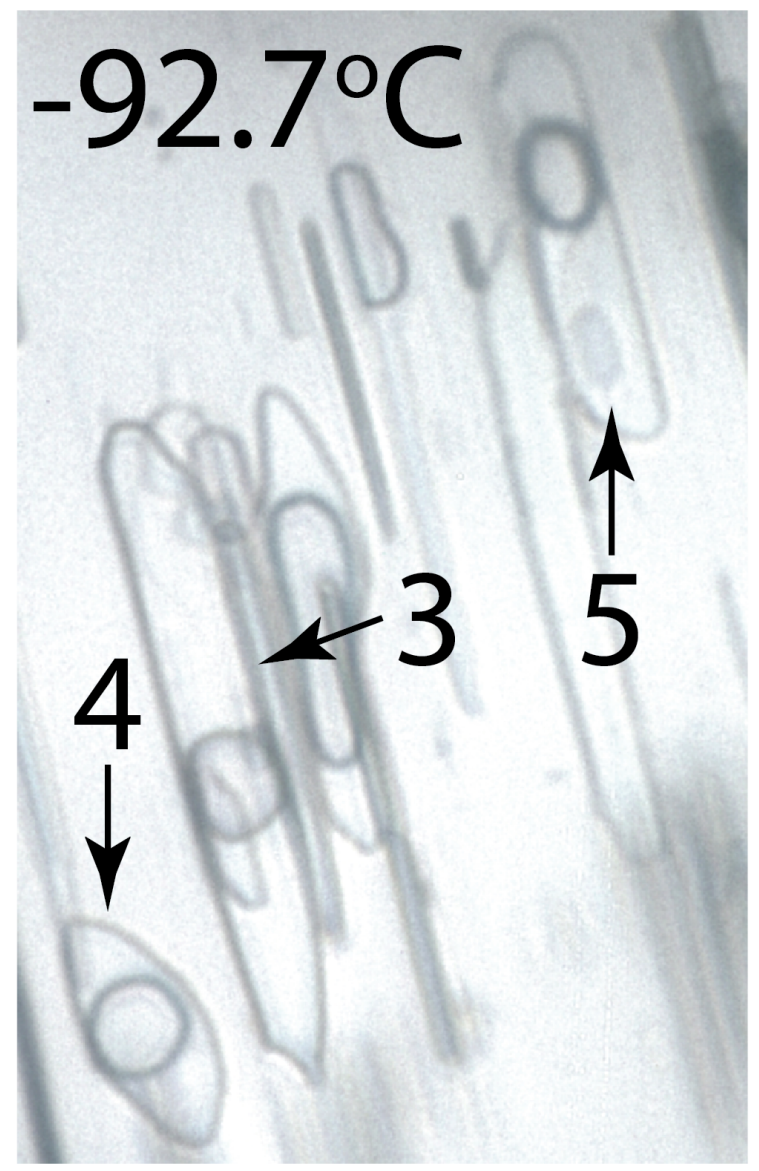


Karmanocky, F. J. III, 2014
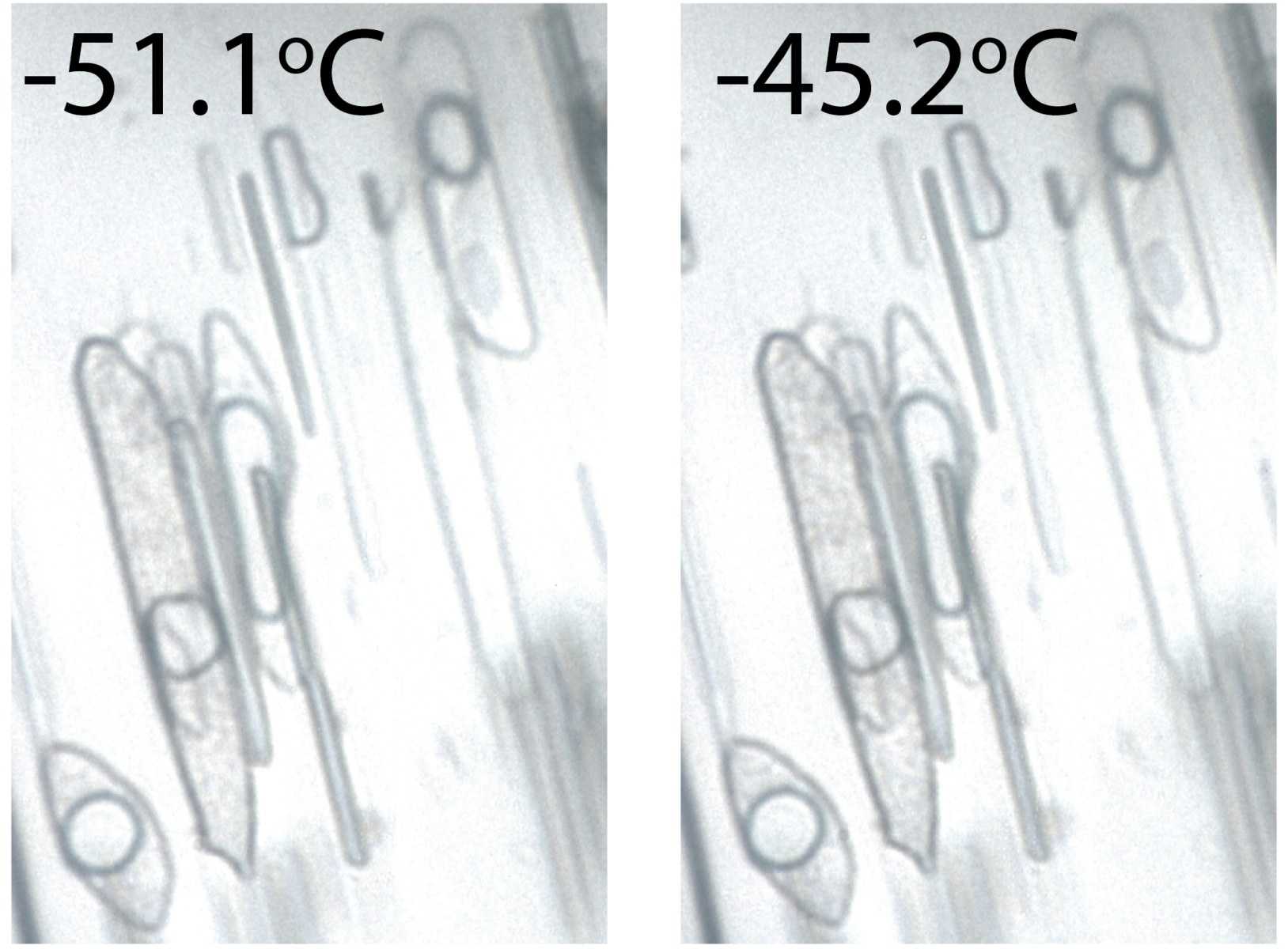
Karmanocky, F. J. III, 2014
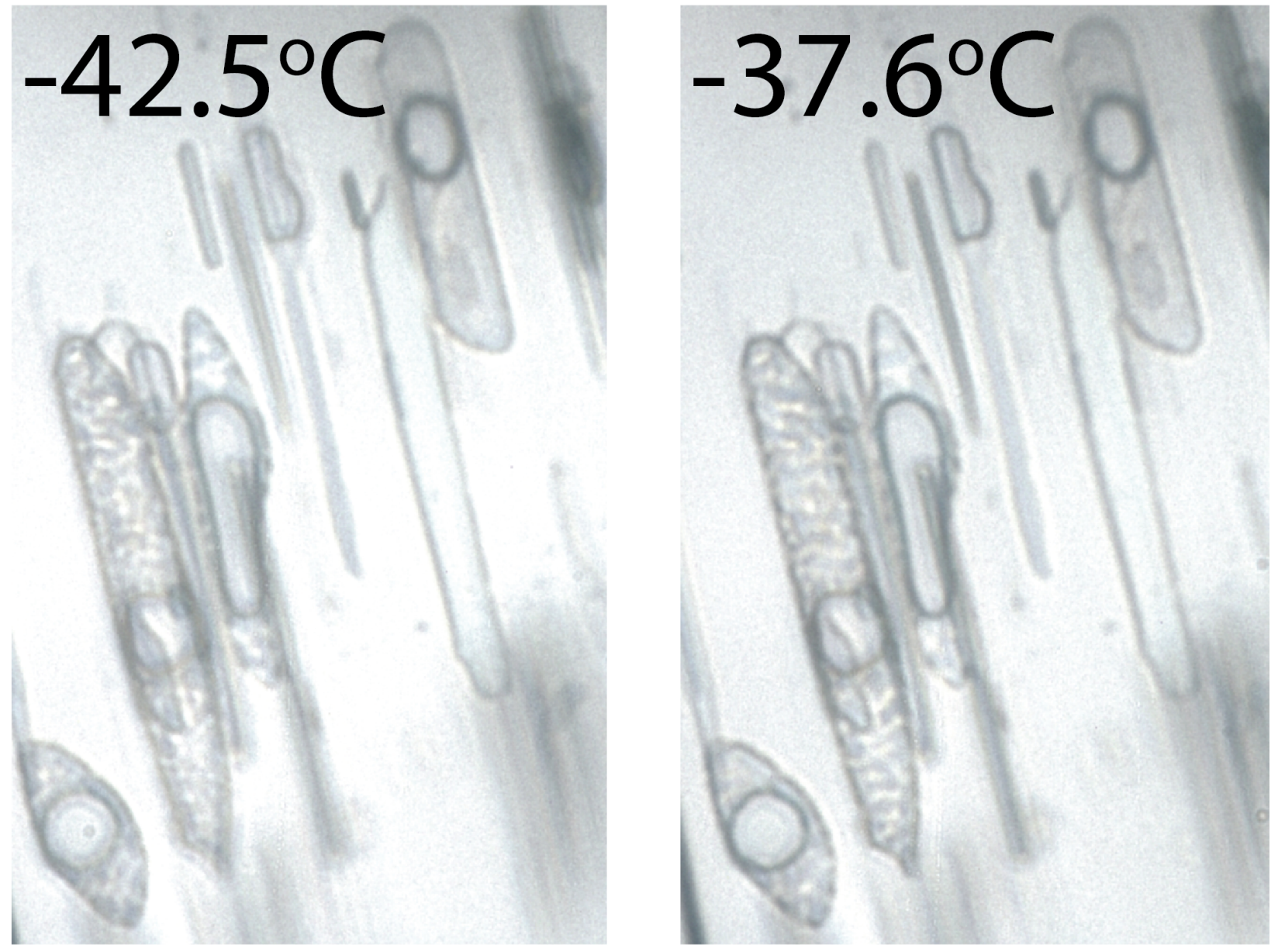
Karmanocky, F. J. III, 2014
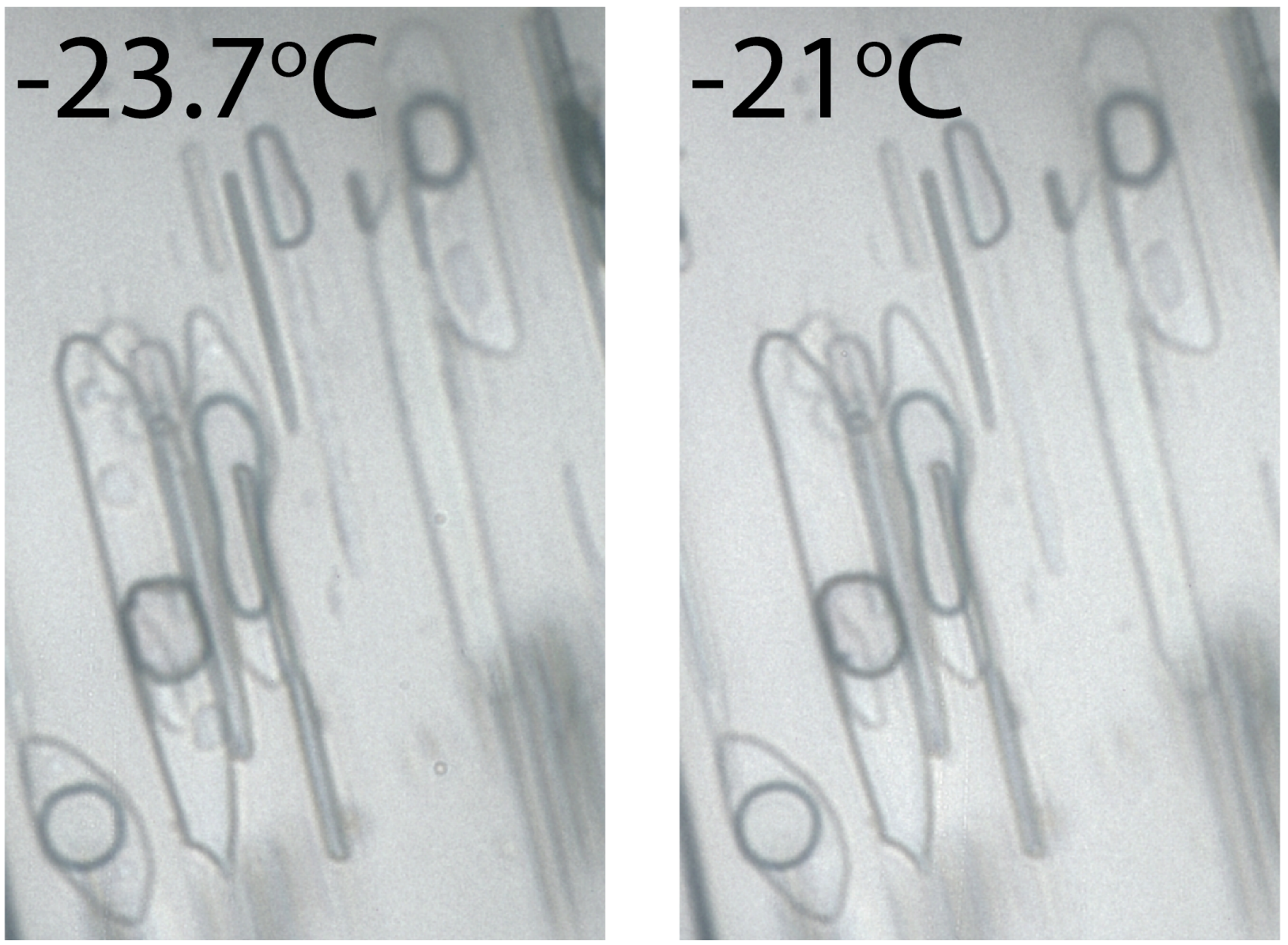
Karmanocky, F. J. III, 2014

\section{Appendix F: Barometric pressure calculations for a range of climactic possibilities at Salar Ignorado}


Karmanocky, F. J. III, 2014
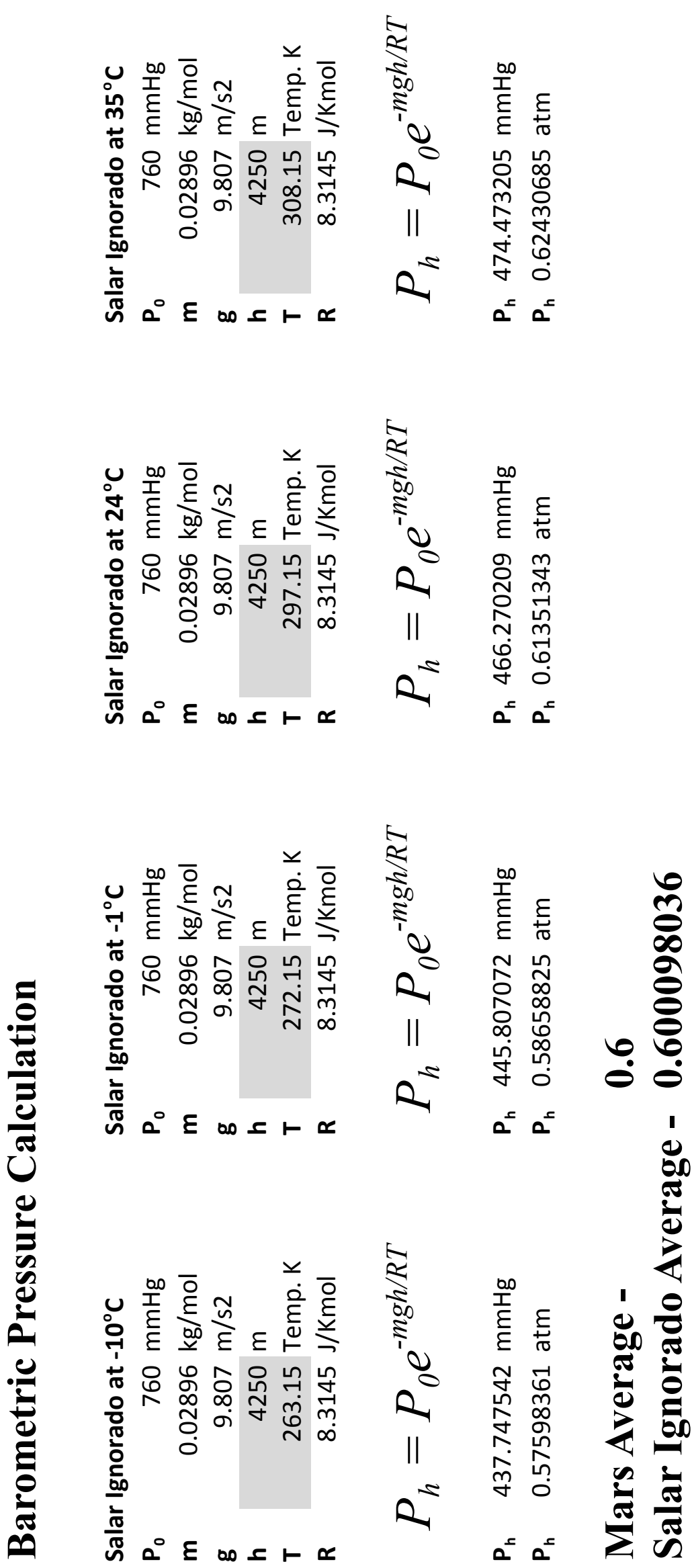